\section{A RESIDENTIAL \\ ENERGY-CONSUMPTION ANALYSIS \\ UTILIZING THE \\ DOE-1 COMPUTER PROGRAM \\ by}

Scott K. Arentsen
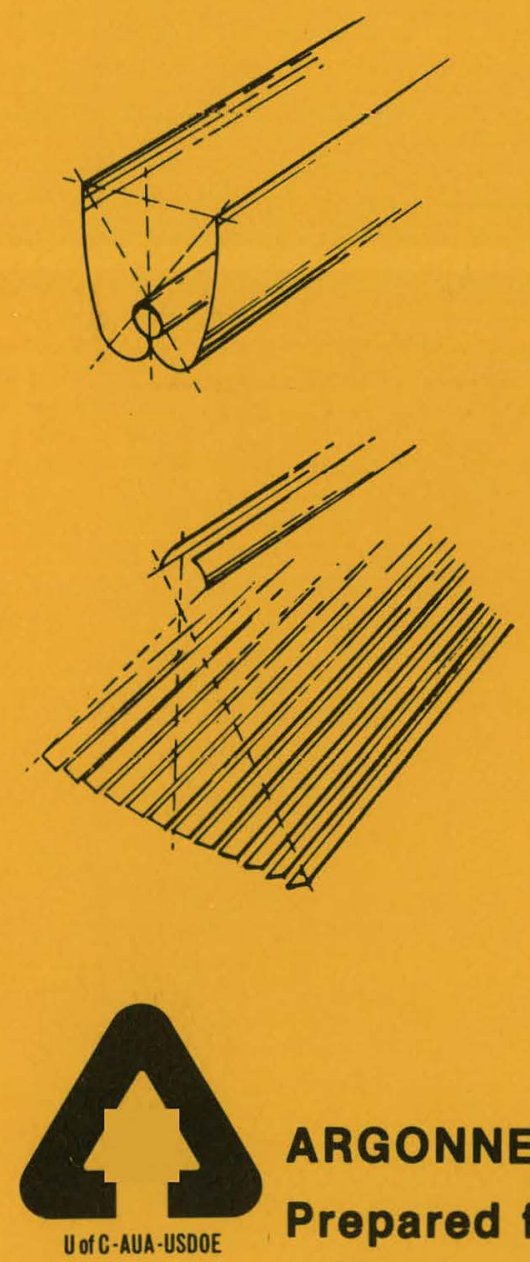

ARGONNE NATIONAL LABORATORY, ARGONNE, ILLINOIS

Prepared for Solar Heating and Cooling

Research and Development Branch, Conservation and Solar Applications, U. S. Department of Energy under Contract W-31-109-Eng-38 


\section{DISCLAIMER}

This report was prepared as an account of work sponsored by an agency of the United States Government. Neither the United States Government nor any agency Thereof, nor any of their employees, makes any warranty, express or implied, or assumes any legal liability or responsibility for the accuracy, completeness, or usefulness of any information, apparatus, product, or process disclosed, or represents that its use would not infringe privately owned rights. Reference herein to any specific commercial product, process, or service by trade name, trademark, manufacturer, or otherwise does not necessarily constitute or imply its endorsement, recommendation, or favoring by the United States Government or any agency thereof. The views and opinions of authors expressed herein do not necessarily state or reflect those of the United States Government or any agency thereof. 


\section{DISCLAIMER}

Portions of this document may be illegible in electronic image products. Images are produced from the best available original document. 
The facilities of Argonne National Laboratory are owned by the United States Government. Under the terms of a contract (W-31-109-Eng-38) among the U.S. Department of Energy, Argonne Universities Association and The University of Chicago, the University employs the staff and operates the Laboratory in accordance with policies and programs formulated, approved and reviewed by the Association.

\section{MEMBERS OF ARGONNE UNIVERSITIES ASSOCIATION}

The University of Arizona Carnegie-Mellon University Case Western Reserve University The University of Chicago University of Cincinnati Illinois Institute of Technology Univercity of Illinois Indiana University The University of Iowa Iowa State University
The University of Kansas Kansas State University Loyola University of Chicago Marquette University The University of Michigan Michigan State University Univercity of Minnesota University of Missouri Northwestern University University of Notre Dame
The Ohio State University Ohio University

The Pennsylvania State University Purdue University Saint Louis University Southern Illinois University The University of Texas at Austin Washingtun University Wayne State University The University of Wisconsin-Madison

\section{NOTICE}

This report was prepared as an account of work sponsored by the United States Government. Neither the United States nor the United States Department of Energy, nor any of their employees, nor any of their contractors, subcontractors, or their employees, makes any warranty, express or implied, or assumes any legal liability or responsibility for the accuracy, completeness or usefulness of any information, apparatus, product or process disclosed, or represents that its use would not infringe privately-owned rights. Mention of commercial products, their manufacturers, or their suppliers in this publication does notimply or connote approval or disapproval of the product by Argonne National Laboratory or the U. S. Department of Energy.

Printed in the United States of America

Available from

National Technical Information Service

U. S. Department of Commerce 5285 Port Royal Road

Springfield, Virginia 22161

Price: Printed Copy $\$ 6.50$; Microfiche $\$ 3.00$ 
Distribution Category:

Heating and Cooling--

Research and Bevelopment (UC-59c)

ANL - 79-32

\begin{abstract}
ARGONNE NATIONAL LABORATORY
9700 South Cass Avenue

Argonne, Illinois 60439
\end{abstract}

A RESIDENTIAL ENERGY-CONSUMPTION ANALYSIS

UTILIZING THE DOE-1 COMPUTER PROGRAM

by

Scott K. Arentsen

Apri1 1979

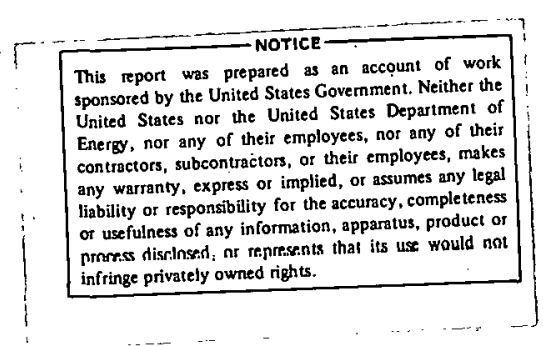

Based on a thesis submitted to the

Faculty of Miami University

in partial fulfillment of

the requirements for the degree of

Master of Environmental Science 
i

THIS PAGE

WAS INTENTIONALLY

LEFT BLANK 


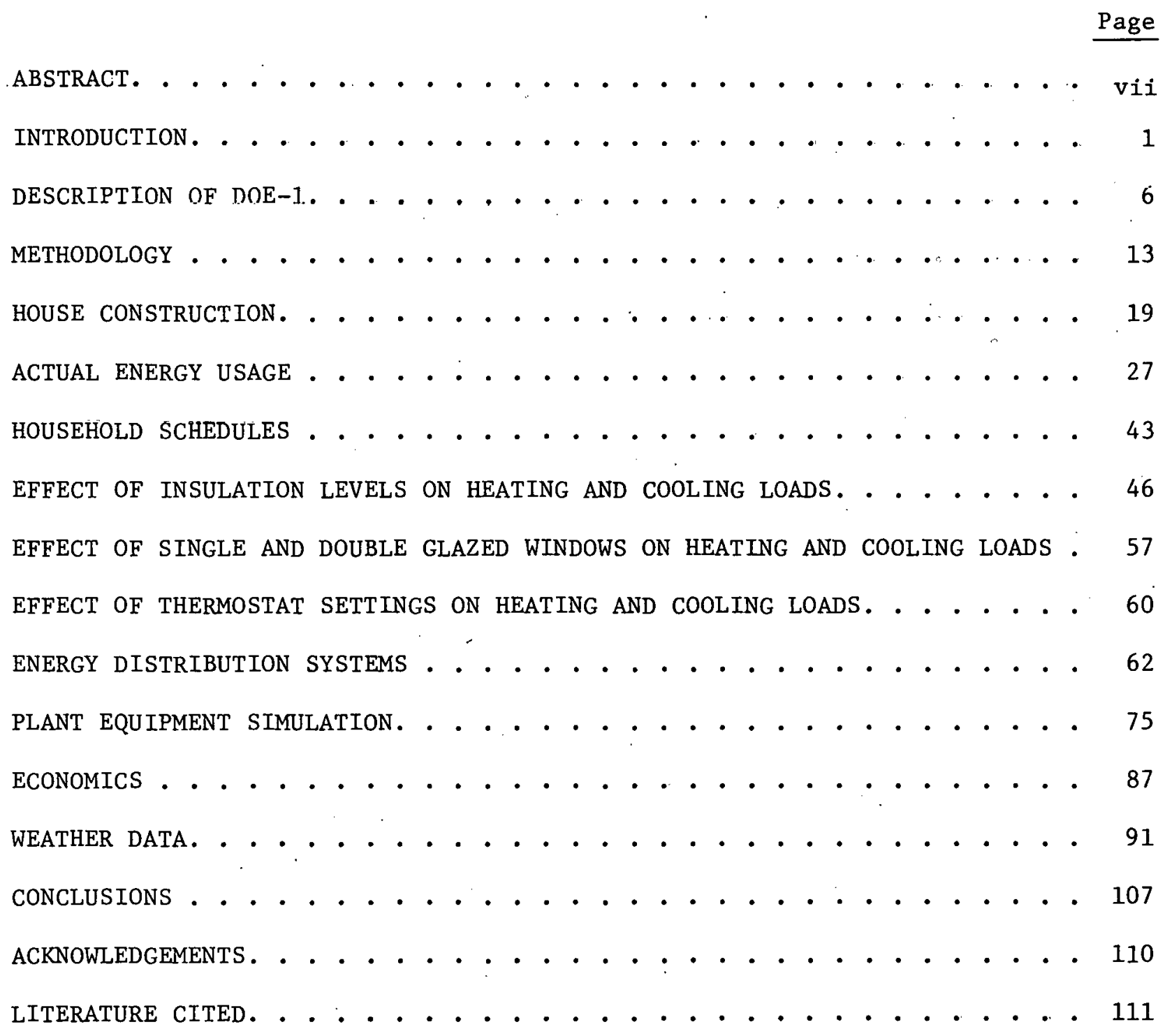




\section{LIST OF FIGURES}

$\underline{\text { No }}$ $\underline{\text { Title }}$

1. DOE-1 computer program configuration . . . . . . . . . . . 12

2. House floor plan . . . . . . . . . . . . . . . . . 23

3. Basement floor plan . . . . . . . . . . . . . . . . 23

4. South wall exterior view . . . . . . . . . . . . . . . . . 24

5. North wall exterior view . . . . . . . . . . . . . . 24

6. West wall exterior view. . . . . . . . . . . . . . . 25

7. East wall exterior view. . . . . . . . . . . . . . . . 25

8. House cross section vièw . . . . . . . . . . . . . . . 26

9. Total annual energy use vs time. . . . . . . . . . . . . . . . . 33

10. Annual total energy bill vs time . . . . . . . . . . . . . . 34

11. Two-month total energy bill vs time. . . . . . . . . . . . . . . 35

12. Two-month gas bill vs time . . . . . . . . . . . . . . . 36

13. Two-month electric bill vs time. . . . . . . . . . . . . 37

14. Gas usage vs time. . . . . . . . . . . . . . . . . . . . 38

15. Electricity usage vs time. . . . . . . . . . . . . . . 39

16. Gas rate vs time . . . . . . . . . . . . . . . . 40

17. Electric rate vs time. . . . . . . . . . . . . . . . 4 41

18. Projected gas rate and projected electric rate vs time . . . . . . 42

19. Household schedules. . . . . . . . . . . . . . . . . . . 45

20. Effect of celling insulation on heating load as calculated by DOE-1. . . . . . . . . . . . . . . . . . . . . 53

21. Effect of ceiling insulation on cooling load as calculated by DOE-1. . . . . . . . . . . . . . . . . . . . . 54

22. Effect of wall insulation on heating load as calculated by DOE-1 . . 55

23. Effect of wall insulation on cooling load as calculated by DOE-1 . . 56

24. Unit heater. . . . . . . . . . . . . . . . . . . 63

25. Single zone fan system with optional sub-zone reheat . . . . . . . 65

26. Un1tarỳ hèat pump system . . . . . . . . . . . . . . . . . 69

27. Steam boiler . . . . . . . . . . . . . . . . . 77

28. Air conditioner compression chiller. . . . . . . . . . . . 77

29. 1957 TRY weather data for Cincinnati, Ohio . . . . . . . . . . 93

30. Frequency of occurrence of hourly dry bulb temperature . . . . . . 105

31. Frequency of occurrence of hourly dry bulb temperature . . . . . . 105

32. Frequency of occurrence of hourly dry bulb temperature . . . . . . 106 


\section{LIST OF TABLES}

No.

1. Residence energy consumption . . . . . . . . . . . . . . . 29

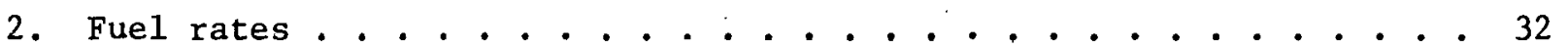

3. Effect of insulation on heating and cooling loads. . . . . . . . . 51

4. Comparison of peak loads with no insulation and with 6" fiberglass fill in ceiling and $2.25^{\prime \prime}$ fiberglass batt in walls . . . . . . . . . 52

5. Effect of double glazed windows on heating and cooling loads . . . 59

6. Comparison of peak loads with single glazed windows and double glazed windows... . . . . . . . . . . . . . . . 59

7. Effect of thermostat settings on heating and cooling loads . . . . . 61

8. Unit heater system design parameters . . . . . . . . . . . . . 72

9. Unit heater system load summary. . . . . . . . . . . . . . . . . . . 72

10. Single zone fan system design parameters . . . . . . . . . . . . 73

11. Single zone fan system load summary. . . . . . . . . . . . . . . 73

12. Heat pump system design parameters . . . . . . . . . . . . . . . 74

13. Heat pump system load summary. . . . . . . . . . . . . . . . 74

14. Central plant energy utilization summary . . . . . . . . . . . . 81

15. Equipment use statistics . . . . . . . . . . . . . . . . . 82

16. Central plant life cycle equipment cost summary. . . . . . . . . . . 82

17. Monthly peak and total energy use summary. . . . . . . . . . . . 83

18. Equipment operation and part load report . . . . . . . . . . . . . 84

19. Plant deiliands satisfied report . . . . . . . . . . . . . . . . . 84

20. Summary of loads met . . . . . . . . . . . . . . . . . 85

21. Electrical demand scatter plot . . . . . . . . . . . . . . 85

22. Life-cycle plant cost summary. . . . . . . . . . . . . . . 86

23. Economics verification . . . . . . . . . . . . . . . 89

24. Life-cycle costs summary . . . . . . . . . . . . . . . 89

25. Life-cycle savings/investment statistics . . . . . . . . . . . 90

26. Single zone fan system load summary. . . . . . . . . . . . . . 109 
THIS PAGE

\section{WAS INTENTIONALLY \\ LEFT BLANK}


ABSTRACT

\author{
A RESIDENTIAL ENERGY CONSUMPTION ANALYSIS \\ UTILIZING THE DOE-1 COMPUTER PROGRAM \\ by $\operatorname{Scott} K$. Arentsen
}

The DOE-1 computer program under development by Argonne National Laboratory, Lawrence Berkeley Laboratory, and Los Alamos Scientific Laboratory is used to examine energy consumption in a typical middleclass household in Cincinnati, Ohio. The program is used to compare energy consumption under different structural and environmental conditions including various levels of insulation in the walls and ceiling, double and single glazing of windows, and thermostat setback schedules. In addition, the DOE-1 program is used to model the house under three energy distribution systems, 1) a Unit Heater, 2) a Single Zone Fan System with Optional Sub-zone Reheat, and 3) a Unitary Heat Pump. A plant equipment simulation is performed to model the heating and cooling plant currently installed in the house. A simple economic analysis of life-cycle costs for the house is done utilizing the economic simulation portion of DOE-1. Utility bills over the past six years are analyzed to gain an actual energy use profile for the house to compare with computer results.

Results of the computer tests indicate that a $35 \%$ savings in heating load may be obtained with the addition of proper amounts of insulation as compared with the house with no insulation. The installation of double glazing on windows may save close to $6 \%$ on heating load. Thermostat set-backs may result in savings of around $25 \%$ on energy consumed for heating. Similar results are achieved with regard to cooling load.

Utility bills show that although gas and electrical consumption for the residence has remained steady over the past six years, energy charges have been rising indicating the increase in utility rates over that period.

Comparison of actual energy consumed by the household (from utility bills) with the computer results shows a $4.25 \%$ difference in values between the two. This small percent difference certainly strengthens the case for future use of computer programs in comparing construction alternatives and predicting building energy consumption. 


\section{INTRODUCTION}

The United States as a country uses approximately one-third of the world's total energy output (Lenihan and Fletcher). The fact that we are immersed in a high energy civilization is news to no one. Energy consumption in this country has increased every year since 1945 (Freeman) and the prospects are for a continuation of the trend unless a drastic change in social attitudes takes place.

Energy consumption is normally broken down into four major categories, 1) industrial use, 2) transportation, 3) residential use, and 4) commercial use. Industrial energy consumption by far outweighs the other three end uses, accounting for over $40 \%$ of the total national consumption (SRI report). Despite its large total consumption, the annual growth rate of industrial energy use is the smallest of the four categories, averaging a $3.9 \%$ increase per year for the decade of the $1960^{\prime} \mathrm{s}$ (SRI report). Input into the industrial sector in 1971 came almost totally from the three major fossil fuels: coal, petroleum, and natural gas and totaled 20,294 trillion BTU (Dupree and West).

Transportation is the second most prolific user of energy, accounting for slightly over $25 \%$ of the nation's energy budget (SRI report). Over $95 \%$ of the energy channeled into the transportation sector in 1971 came from petroleum (Dupree and West). Annual growth rates of energy consumed for transportation amounted to $4.1 \%$ during the decade of the $1960^{\prime}$ s (SRI report).

Commercial energy use is considered the leasl energy consuming sector of the four main end uses, accounting for approximately 10,303 trillion BTU in 1971 (Dupree and West). Despite this fourth place ranking, commercial energy consumption still accounts for 6108 e to $15 \%$ of 
national energy consumption (SRI report). The most significant aspect concerning the commercial cațegory is that its annual growth rate of $5.4 \%$ during the decade of the 1960 's was the largest growth of the four energy use areas (SRI report).

Residential energy consumption is the most significant area with regard to this report. Energy use within the residential sector accounts for about $20 \%$ of the national consumption total (SRI report). The annual growth rate of $4.8 \%$ per year during the decade of the $1960^{\prime}$ s brought the total residential energy consumption to about 13,351 trillion b'lU for 1991 (Dupree and West). The increase in residential energy consumption may be linked not only with an $11 \%$ increase in population during the $1960^{\prime} \mathrm{s}$, but probably more directly with a $17 \%$ increase in the number of households (Ford Foundation report). The vast majority (88\%) of energy use within the household is consumed for space heating and cooling, water heating, refrigeration, and cooking (Staff Study on the Potential for Conservation) with space heating and cooling alone accounting for $60 \%$ of the total (Freemail). By 1980 it is projected that residential space heating and cooling will require 11 quadrillion BTU of energy which would represent two thirds of the projected residential energy consumption during that year (Staff Study on the Potential for Conservation).

Residential space heating is accomplished using eillet electricity or fossil fuels direccly, mainly oil or natural gas. Space heating in the residential sector using electricity showed an annual growth rate of over $20 \%$ during the decade of the 1960 's (SRI report). Despite this exceptional growth rate, electrical space heating for houses represented only $6.75 \%$ of the total residential space heating use in 1968 (SRI report). The remainder is divided almost evenly between natural gas and petroleum products. Of course the fraction of homes heated electrically has 
increased significantly since that time. Of the total energy utilized in this country, residential space heating accounted for $11 \%$ in 1968 (SRI report).

The second most prolific use of energy within the household is for hot water. It would be safe to assume that virtually every home has a water heater, as only $8 \%$ of the dwellings were without one in 1968 (SRI report). At that time gas water heaters outnumbered electric water heaters by almost a three-to-one count (SRI report). However, electricity was experiencing a very rapid growth into the water heating sector and has undoubtedly significantly reduced that ratio. Total energy consumption used for water heating amounted to 1736 trillion BTU in 1968, which added up to $2.9 \%$ of the total national energy consumption (SRI report). In addition to the total energy requirement for water heaters increasing, . the energy use per water heating unit has increased from 4272 Kwh per electric unit and 25.5 million BTU per gas unit in 1960 to $4490 \mathrm{Kwh}$ per electric unit and 27.2 million BTU per gas unit in 1968 (SRI report). This represents the increased hot water usage by households due to items such as diswashers and automatic washing machines being added to the list of residential necessities.

Cooking represents the third of the major energy consumption areas within the residential sector. By 1960 , close to $96 \%$ of all households were equipped with either gas or electric ranges (SRI report). Total per unit energy consumption for electric range cooking actually decreased. from 1225 Kwh per range in 1960 to 1180 Kwh per range in 1968 (SRI report). Annual gas range consumption remained stable at about 10.6 million BTU per unit throughout the decade (SRI report). Total energy consumption for cooking (both electric and gas) was approximately 902 
trillion BTU during 1968. This represents about $1.2 \%$ of total national energy consumption (SRI report).

Refrigeration rounds out the four major energy consumption areas in the residential sector. By $1969,96 \%$ of all households contained refrigeration units (SRI report). The majority of refrigerators in this country are electric. Per unit energy consumption ranged from 790 Kwh per unit in 1960 to $1270 \mathrm{Kwh}$ per unit in 1968. This represents a total energy consumption of 692 trillion BTU. This 692 tililion B'lu amounts th $1.1 \%$ of Lulal hational energy consumption (S̄EI report):

Additional residential energy consumption categories include clothes drying, air conditioning, lighting, and other miscellaneous uses. However these constitute only a minor energy sink in the home, amounting to on ly $3.1 \%$ of total national energy consumption and $16 \%$ of the residential energy consumption (SRI report).

As mentioned previously, residential space heating accounts for $11 \%$ of total energy consumption. 'In 1971 the combined household and commercial energy usage amounted to 17,441 trillion B'IJ (Impree and West). The energy consumed by these two categories is expected to reach 23,860 trillinn RTU by $1980,27,700$ trillion BTU by 1986 , and climb to 39,630 trillion BTU by the year 2000 (Dupret and West). A large persentage of this energy is wasted through a combination of excess environmenlal design rcquirements, the necessity for overcoming unwanted heat loss or gain resulting from poor structural design, inefficient operating practices, and inappropriate selection and design of building systems. If this nation is to survive and society is to conlinue as we know it, energy will be a pivotal issue in determining that end. The issue of energy has already 
come to the forefront of national policy priorities. It is generally accepted that patterns of energy consumption will need to be shifted to reduce dependence on dwindling supplies of fossil fuels. The conservation of presently available fuels and the conversion to solar heating and possibly solar cooling have been mentioned as viable energy alternatives as conventional sources of fuel grow more scarce. This report will examine energy consumption in the residential sector, specifically by one household, using computer modeling techniques. It is hoped that computer programs, such as the one used in this project, will become a major factor in the reduction of energy usage by buildings in the future. 


\section{DESCRIPTION OF DOE-1}

As pointed out in the introduction to this report, the energy used to operate buildings in the commercial and residential sectors can contribute significantly to total national energy demand. In fact, building energy consumption accounts for about one-third of total U.S. energy end use. Since this is the case, it would be wise to attempt to reduce energy consumption in this area in an effort to hold down rising total energy demands. The major factor contriburing to this tul is the effirient use of energy within buildings and one tool recently déveloped lu-assist in this attcmpt is the computer program. DOE-1 (formerly entitled (al-ERDA) is one such program.

The development of DOE-1 was begun as a joint project involving Argonne National Laboratory, Lawrence Berkeley Laburatory, and Los $\Lambda$ lamoe Scientific Laboratory. Support for the project is provided by the State of California under the auspices of its Energy Resources Conservation and Development Commission (ERCDC) and by the United State Energy Research and Development Administration (ERDA), now incorporated into the Department. of Energy (DOE). At the present, the program is still under development as it is being revised and edited. Some portions of the program are as yet not operational but expect to be within the near future.

The object of this reputt is not the documentation of the DOF,-1 computer program. However, a basic description of the components involved in the program itself may be helpful in understanding the modeling process undertaken as the main aspect of this paper. DOE-1 consists of four elemental computational units: 1) LOADS, 2) SYSTEMS, 3) PLANT, and 4) ECONOMICS, as well as several other features, plus a unique computer language used for input of data. 
The Building Design Language (BDL) is the computer language designed to instruct the computer in handling the mathematical models created for simulating building energy demands. The major computational components of DOE-1, the LOADS, SYSTEMS, PLANT, and ECONOMICS programs, are controlled using the BDL to describe the thermal model in question. BDL allows the user of DOE-1 to select the appropriate weather data; describe the geometry and construction of a building; dictate its energy supply equipment; impose schedules for occupancy, equipment operation, and lighting; and outline economic parameters critical to the energy operation of a building. BDL also allows the user to select data frequently used in thermal models from a computer library containing such elements.

The LOADS program calculates the heating and cooling loads not only for the building itself, but for each designaled space within the building. For each hour of the year ( 8760 hours/year), heat transfer through the external surfaces of the building is determined based on several factors. The LOADS program breaks down the calculations and computes heat gains and losses through walls, roofs, floors, windows, and doors. This allows a clearer insight into which of these areas contribute most to the thermal loads of a particular building. The effects of thermal mass, insulation levels and placement, external ambient conditions, sun angle, cloud cover, building location, orientation, and other architectural features such as shading, are all considered in determining heat transfer by radiation and conduction through building surfaces. The difference between internal and and external conditions is used to calculate infiltration loads. The use of energy for lighting and equipment within the building is also computed according to operational schedules assigned by the user. 
In addition to the loads calculated according to the above description, the LOADS program takes into account the latent and sensible heat supplied to a building or space within a building by occupants of the structure. Addition of heat by equipment operating in the building is computed and its effect is also included in the LOADS results.

It should be pointed out that all LOADS calculations are carried out based upon a fixed internal temperature as specified by the user. In other words, hourly weather data is used to calculate a building or spar.p thermal load based upon a set internal temperature for the entire perind of simulation. Because of this, the output from the LOADS program may bear little resemblance to the actual thermal requirements for the building. It does, however, permit comparison of the thermal performance of various exterior surfaces bastu vin a fixcd interior temperature. The SYSTEMS program allows for variable internal temperature, such as daily thermostat setbacks or seasonal adjustments, in its calculations of actual thermal loads.

The SYSTFMS program simulates the operation of "secondary" Heating, Ventilating, and Air Conditioning (HVAC) systems used to supply heating or cooling to the spaces within the building being modeled. Secondary systems are defined as equipment which distributes the needed energy to the space or building, as opposed to "primary" systems which are energy conversion devices such as furnaces, boilers, and chillers. These "primary" systems are modeled later in DOE-1 under the PLANT program.

As indicatcd earlier, the hourly space loads as calculated by the LOADS program may be significantly different from the actual thermal loads 
as perceived by the heating and cooling distribution system. This is due to ventilation air requirements, seasonal temperature fluctuations, and thermostat setback schedules not modeled in the LOADS program. The SYSTEMS program utilizes output from the LOADS program and calcuiates the actual hourly energy requirements that must be supplied by the Heating, Ventilating, and Air Conditioning distribution system based on the input specified by the user in terms of these variables. "The purpose of the SYSTEMS simulation program is, therefore, two-fold:

$$
\begin{aligned}
& \text { 1) provide information for sizing "secondary" energy } \\
& \text { distribution system components, based upon peak } \\
& \text { (or design day) heating and cooling requirements. } \\
& \text { 2) simulate each dietribution system as it responds to } \\
& \text { space thermal requirements, and determine the demand } \\
& \text { that system is imposing upon the central heating and } \\
& \text { cooling plant. "* }
\end{aligned}
$$

The PLANT program models the performance of "primary" energy supply equipment which uses fuels, such as oil, gas, or solar power to provide heating and cooling for a structure. Using results from the LOADS and SYSTEMS programs, in terms of hourly building and HVAC requirements, the PIANT program is able to simulate the operation of each plant component, ranging from conventional equipment to hybrid systems involving on site generation of electricity. Results of the PLANT program are a series of plant operational statistics including equipment costs, summarized energy usage and energy costs, life-cycle costs, and other plant statistics.

*From DOE-1 User's Manual, p. 4-1. 
This output can then be utilized to determine improved design or operational configurations in order to facilitate more economical energy consumption for a particular system. Comparison runs may also be performed to evaluate several types of plant systems in terms of overall energy and cost efficiency.

One important option included in the PLANT program is the Solar Design Package. This multi-level design tool allows for the analysis of both liquid and air solar enesgy systems. The solar simulation may be pertormed either wieh "preconeced" oulur yotwing anplind with the program or on a component by component basis. The component approach allows more flexibility in the modeling process as each element of the solar system (collectors, tanks, pumps, etc.) may be utilized within the solar system in a unique way. In addition, each of the "preconnected" liquid and air systems supplied with the PLANT program has two levels of complexity, allowing a tradeoff of accuracy and detail on the one hand with computing $E$ line and cusls on the other.

The ECONOMICS program uses output from the LOADS, SYSTEMS, and PLANT program as well a input supplied by the user to calculate lifecycle costs of building operation. The results of the ECONOMICS program include: 1) cost savings, 2) savings to inveslutul ratio ( 8 IR), 3) fuel savings, 4) fuel savings to investment ratio, and 5) discounted payback period. Input from the user consists of: 1) interest rate, 2) labor inflation rate, 3) materials inflation race, 4) energy inflacion rate, 5) project $1 \mathrm{ife}, 6)$ cost of labor $(\$ / \mathrm{hr})$, and 7$)$ site cost factors: The present cost of electricity, natural gas, coal, and oil may also be entered by the user in addition to fuel cost escalation factors. Based on this information, the ECONOMICS program then is able to calculate the 
life-cycle costs of several energy programs and these "investment statistics" can then be utilized to analyze several competing building alternatives in terms of overall cost effectiveness.

Figure 1 is a graphic illustration of how the DOE-1 computer program is designed and shows. the interrelationship of the component parts. 


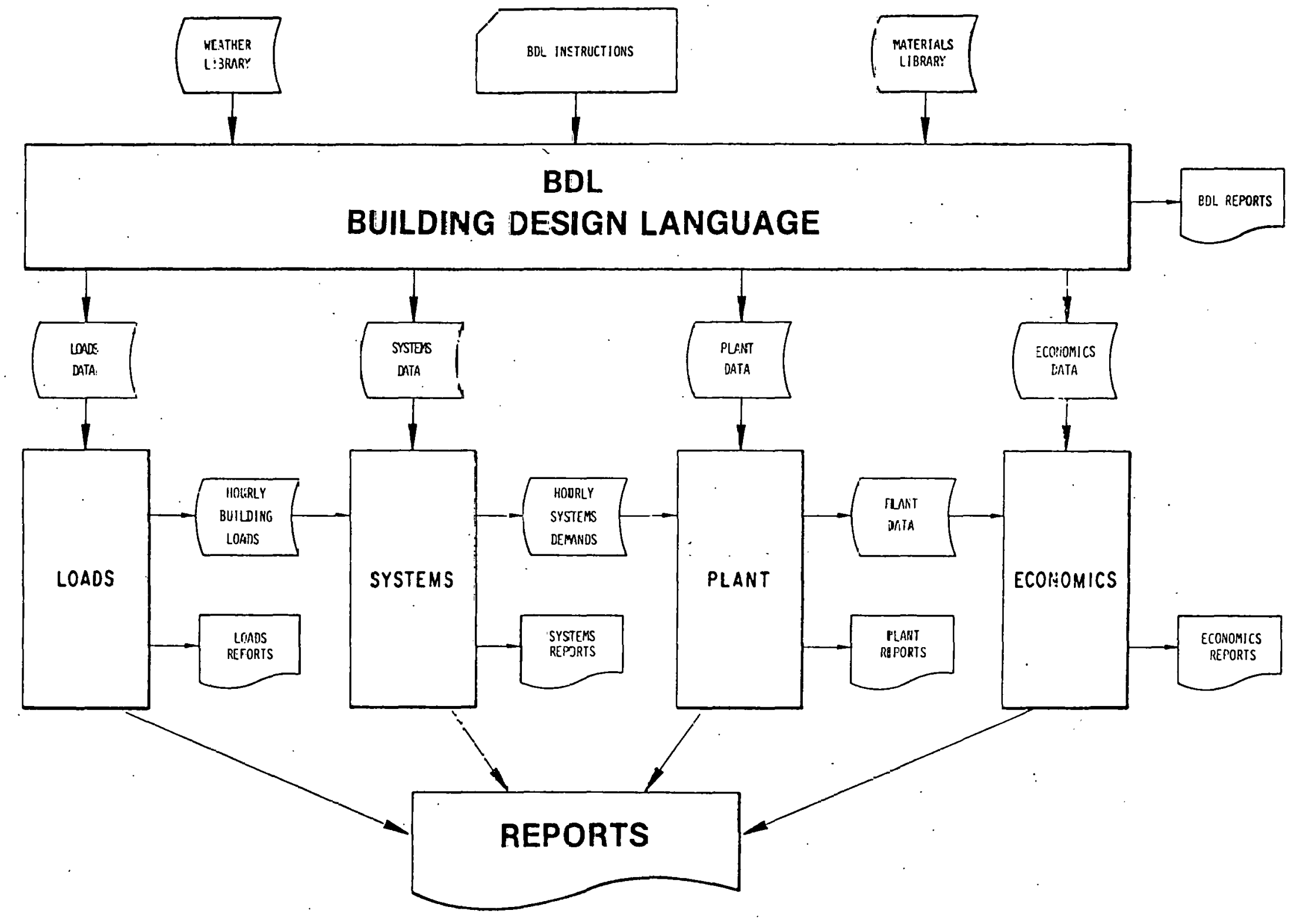

Fig. 1. DOE-1 computer program configuration 


\section{METHODOLOGY}

The object of this study is to examine energy utilization within the residential sector. Specifically, computer modeling will be used to calculate theoretical energy demands for a typical residential structure under various structural conditions. The residence used for this study is not a random selection, but nevertheless does represent an average middleclass suburban dwelling with an appropriate middle-class living style, characteristic of this, the largest segment of American society. Access to utility records, construction details, and living habits all contributed to the selection of this residence for the study. The house is situated in southwest Ohio in the southeast portion of Butler. County with a location of $39.3^{\circ} \mathrm{N}$. Latitude and $84.3^{\circ} \mathrm{W}$. Longitude. Proximity to the city of Cincinnati, Ohio is indicated by the fact that utility service to the neighborhood is supplied by the Cincinnati Gas and Electric Company.

The structure itself is a single story, three bedroom, ranch style house with approximately 1545 square feet of floor area on the first floor and approximately 1350 square feet of basement floor area. Schematic drawings with descriptions are included in a later section to illustrate floorplans, cross sectiono, and exteriur wall surfaces.

The DOE- 1 computer program as described earlier is the tool utilized for this study. The program is flexible enough and cheap enough to use to allow an investigation of several elements affecting home energy use. It has been noted that the DOE-1 program is still under development and several features are not operational as of this writing. The use of this program by someone not involved with its development helps to point out problem areas which need to be clarified or corrected so that utilization by the public is facilitated. As is often the case, developers of a 
concept cannot be aware of all the hidden idiosyncrasies and pecularities that such a project contains. It is hoped, therefore, that this study will benefit the developers of DOE-1 (Argonne National Laboratory, Lawrence Berkeley Laboratory, and Los Alamos Scientific Laboratory) in such a way as to assist in the completion of the program.

Basically there are several changes an individual homeowner is able to perform on his dwelling to increase energy efficiency. These include insulation in the walls and ceiling, addition of storm windows and doors with weather seṛippling, and lliesmustat adjuotmonte. It is these relatively inexpensive, cost-effective procedures that can be easily instituted by the homeowner and which are most effective in achieving a reduction in energy usage. Major structural considerations, such as large south facing window area, thermal masses incorporated in construction, etc., are practical only when instituted at the design stage of any structure. It is safe to say that these modifications are not possible on an existing house. Therefore, the first procedure in utilizing the DOE-1 program is to study the effect the simple energy conservaliuu measures have on energy consumption.

Initially the dwelling is modeled as it is currently maintained in terms of insulation, slusu windowg and doors, aul temperature sct ings. Insulation levels are six inches of fiberglass fili in the ceiling $(\bar{k}-20)$ and two and one quarter inches of fiberglass batt in the walls $(R-7)$. All windows are double glazed. The south facing windows are wood framed with a vertical mode of operation and have separate storm windows. The remaining windows are horizontal sliding aluminum frame casemenl windows. There are no separate storm windows on these fenestrations, however, the frames contain two panes of glass separated by an air space. The windows are well 
fitted with weather stripping. All entry ways are complete with storm doors. Temperature settings have been traditionally $68^{\circ} \mathrm{F}$ daytime and $63^{\circ} \mathrm{F}$ nighttime during winter and a constant $78^{\circ} \mathrm{F}$ during summer. Occupancy, lighting, and equipment operation schedules have been approximated as nearly as possible to assure as accurate a profile of actual current. energy use as possible.

Insulation levels in the ceiling are then changed, keeping all other variables constant, to determine the effect of ceiling insulation on energy consumption. Values tested were: 1) no insulation in the ceiling; 2) 3.0 inches $(R-10) ; 3) 6.0$ inches $(R-20) ; 4) 9.0$ inches $(R-30)$; and 5) 12 inches $(R-40)$ of fiberglass fill. The procedure is repeated for wall insulation using values of: 1) no insulation; 2) 2.25 inches ( $R-7)$; 3) 3.5 inches $(R-11)$; 4) 6.12 inches $(R-19)$; 5) 8.36 inches $(R-24)$; and 6) 9.68 inches $(\mathrm{R}-30)$ of fiberglass batt insulation. Once again all other variables are kept constant to isolate only the effect of adding wall insulation.

One compromise made necessary by the fact that DOE-1 is incomplete was the elimination of the attic in the modeling procedure. It was discovered that as insulation was added to the ceiling separating the conditioned first floor from the unconditioned attic, the calculated heating and cooling loads for the building increased. This is in direct disagreement with reality. Calculations of zone to zone heat transfer within the building were in error. In order to eliminate the problem, the modeling of the attic as a separate space within the building was discontinued. Instead, insulation was added to the roof of the building for purposes of computing heating and cooling loads. This undoubtedly results in something other than a true picture of actual energy consumption. However, the gross effect of insulation can still be evaluated. The problem has been corrected since the writing of this report. 
Insulation is probably the single most important structural factor influencing energy consumption in a building. However, double glazing of windows and addition of storm doors can also reduce heating and cooling demands. As indicated earlier, the house as currently constructed makes use of double glazing on all windows and doors. In order to determine what effect the number of window panes has on energy consumption, the house is modeled with only single glazed windows and doors and the results are compared with the baseline data from the test house. As with the insulation procedure, all other components are kept constanc su ds lu isolate only the effect of the winduw glazing. There is no mathod presently available within DOE-1 to test the effect of triple glazing of windows since the maximum allowable number of window panes is two. One would suspect, however, that the incremental savings in energy wilh Liple paned windows may not justify the cost of adding them to the house.

The effect of thermostat settings on energy consumption is determined by comparing the results of the LOADS subprogram and the SYSIEMS subprow gram for a single DOE-1 run. Under the description of DOE-1 it was mentioned that the LOADS portion of the program calculates building energy demands based on a fixed internal temperature as specified by the user. The SYSTEMS subprogram allows the institution of temperature variation. By comparing the output of the two subprograms, Llie effect of thcrmotat. settings may be determined. The year-round average indoor temperature is computed to be $70^{\circ} \mathrm{F}$. This is the constant temperature used in the LOADS subprogram. Temperature settings under the SYSTEMS subprogram are $68^{\circ} \mathrm{F}$ daytime and $63^{\circ} \mathrm{F}$ nighttime during the heating season and $78^{\circ} \mathrm{F}$ day and night during the cooling season. Although these thermostat setpoints would seem to lend themselves to a yearly average temperature of close 
$70^{\circ} \mathrm{F}$, the result of lowering the temperature in the winter and raising it in the summer has a considerable effect on energy consumed as documented further on in this report.

Under the SYSTEMS portion of DOE-l, several different HVAC (Heating, Ventilating; and Air Conditioning) systems are simulated. The DOE-1 program is able to model 17 different energy distribution systems. These range from simple single space systems for residences and small buildings to large complex systems or combinations of systems used in commercial or industrial applications. Three systems were chosen for inclusion in this simulation as being plausible distribution alternatives for this particular dwelling. They are: 1) a Unit Heater (UHT); 2) a Single-zone Fan System with Optional Sub-zone Reheat (SZRH) and; 3) a Unitary Heat Pump System (HP). Each of these three systems are described in more detail with diagrams in the "Energy Distribution Systems" section of this report: Suffice it to say here that these three systems are modeled in an effort to determine which system should be used with the modeling of the PLANT portion of DOE-1 and to gain insight into which system is the optimum for residential energy distribution.

The PLANT program of DOE-l was originally intended to be used in this project for a comparison of the conventional fossil fuel and electric heating plant with a solar plant. However, it was discovered in attempting to perform the solar simulation that the Solar Design Package of the PLANT subprogram is not operational at the present time. Therefore, the comparison procedure was eliminated and the test house is simulated under the PLANT portion of DOE-l:utilizing the conventional heating and cooling equipment now in the residence. One important modification is necessary in the plant simulation due to the fact that the DOF-l program io not yet 
complete. The current edition of the program contains no method of modeling a typical natural gas forced air furnace, the type of plant presently maintained in the test residence. Because of this, the test house's heating plant is simulated as a steam boiler using input data similar as possible to the actual operating characteristics of the natural gas furnace. In this way, the plant operation statistics obtained from this simulation will be useful in analyzing the operation of the actual plant equipment even though the actual plant is not being modeled. The couling plant simulated is a conventional electric central alr condiliuning unit. The ECONOMTCS subprogram of DOE-I was in turn intended to utilize output from the solar simulation to compare several different collector areas in terms of their economic feasibility for this structure. However, since the solar simulation was not performed, the ECUNOMICS proglati is used for a life-cycle cost calculation for the house itself. The results of this modeling procedure are included in the section entitled "ECONOMICS." 
HOUSE CONSTRUCTION

The following drawings are schematics illustrating the construction of the residence as modeled in this project. As indicated previously, the house is a ranch style, single story, three bedroom structure with approximately 1545 square feet of first floor living space. In addition to the three bedrooms, there are one and a half bathrooms, a living room, a dining room, and a kichen-den separated by a waist-high counter. The garage is adjoining the house on the southeast corner. The layout of the first floor is shown by the floorplan labeled Figure 2. Note that the house is situated at an angle approximating $24^{\circ}$ east of true north. There is a small overhang which shades the front entryway and extends along the south-facing living room wall. In addition, there is a large patio cover which extends out from the north wall of the den and provides partial shading to this portion of the house. This patio cover is not shown on the drawings as it was added to the house after the drawings were completed.

Figure 3 shows the basement floorplan. The basement is smaller in area than the first floor as it does not extend beneath the den. There is a door along the north wall from which stairs climb to ground level on the outside.

Figures 4 through 7 show external views of the four walls.. Figure 4 illustrates the south wall and the front of the house. Note the abundance of window area, especially the large living room picture window. This is particularly important with regard to energy consumption. In winter when the sun is low in the sky, the house is able to pick up additional heat energy from solar radiation penetrating these windows. This acts to reduce the heating load that must be supplied by artificial methods, such as the furnace. In the summer when the sun is high in the sky, the overhanging 
eaves shade a substantial portion of this window area and thus act to reduce the cooling load demand on the air conditioning system. There is also a significant exposure of basement wall to the west end of the south wall. This undoubtedly has an impact on energy consumption since basement walls are not insulated to the degree other above ground walls are. In addition, earth is a good insulator and exposure of the basement wall results in the loss of this property and heat leakage may occur. The roof is black asphalt roofing shingle which in itself acts as a solar collector. The dark material absorbs incoming solar radiation and a certain percentage of this energy is converted to heat and transmitted to the attic space beneath. In winter this may help to reduce heat loss from the first floor since the temperature difference between the two spaces is reduced and therefore heat transfer between the first floor and the attic is inhibited. In the summer this occurrence may be a liability as increased attic temperatures may increase the building cooling load. However, there is no way to determine this effect using the DOE- 1 computer program and the influence can be assumed to be relalively minor in comparison to other variables such as insulation, temperature settings, etc:

Figure 5 shows the north wall and the back of the house. Once again there is a significant amount of window area. In this case this north exposed window area does not receive as much incoming solar radiation as those windows on the south wall. Because of this, there is the potential for heat loss from these windows in the winter. The fact that the house is situated so that this wall faces slightly east does allow some morning sun to enter the windows and subsequently moderates the heat 1039 to a degras. However, if one were designing an energy efficient dwelling, it would be advantageous to eliminate as much of the window area as possible on the north wall. 
It should be mentioned at this point that all windows on the house are double glazed with one of two types of designs. The wood double hung windows located on the south wall employ traditional separate storm windows. The aluminum frame sliding windows located elsewhere in the house have two panes of glass sealed in the frame itself. Both the front door and the basement door include storm doors. In addition, there is weather stripping. located around doors and windows to reduce infiltration.

- Figure 5 also shows a substantial exposure of basement wall as well as basement windows. As mentioned previously this may represent a significant. energy loss as this type of wall is not insulated to the degree other above ground walls are.

Figure 6 illustrates the west wall with its basement wall exposure and window area. The gable above the first floor represents the end of the attic and has an exterior layer of aluminum siding. Figure 7 shows the east wall. The only window on this wall is on the garage and therefore has little effect on the conditioned space energy demands.

Figure 8 is a cutaway view that allows examination of the walls, roof, ceiling, and floor construction. The walls are composed of a three-inch Wick veneer with a cementing one inch layer of mortar grout. Insulation is in the form of 2.25 inch fiberglass batts with an $R-v a l u e$ of $R-7$. This is sealed in the walls by $5 / 8$ inch gypsum board and plaster. The basement walls are composed of one inch cement mortar grout covering a wall of eight inch concrete block. Floors are made up of a 5/8 inch layer of plywood subfloor underneath $3 / 4$ inch hardwood flooring. This is covered in some cases by linoleum tile as in the kitchen or by carpeting as in the den. Ceilings are composed of $1 / 2$ inch gypsum board and plaster with six inches of fiberglass fill insulation $(R-20)$ layered above in the attic. The roof 
is a combination of asphalt shingle material on a $5 / 8$ inch layer of plywood sheathing.

The preceding description is a basic explanation as to how the model house is constructed. It represents the typical construction employed in the housing industry at the present time. While it does an adequate job of energy conservation, most assuredly as energy costs continue to increase, there will be a greater degree of energy efficient construction techniques employed to reduce the energy consumption of the average home in the future. 


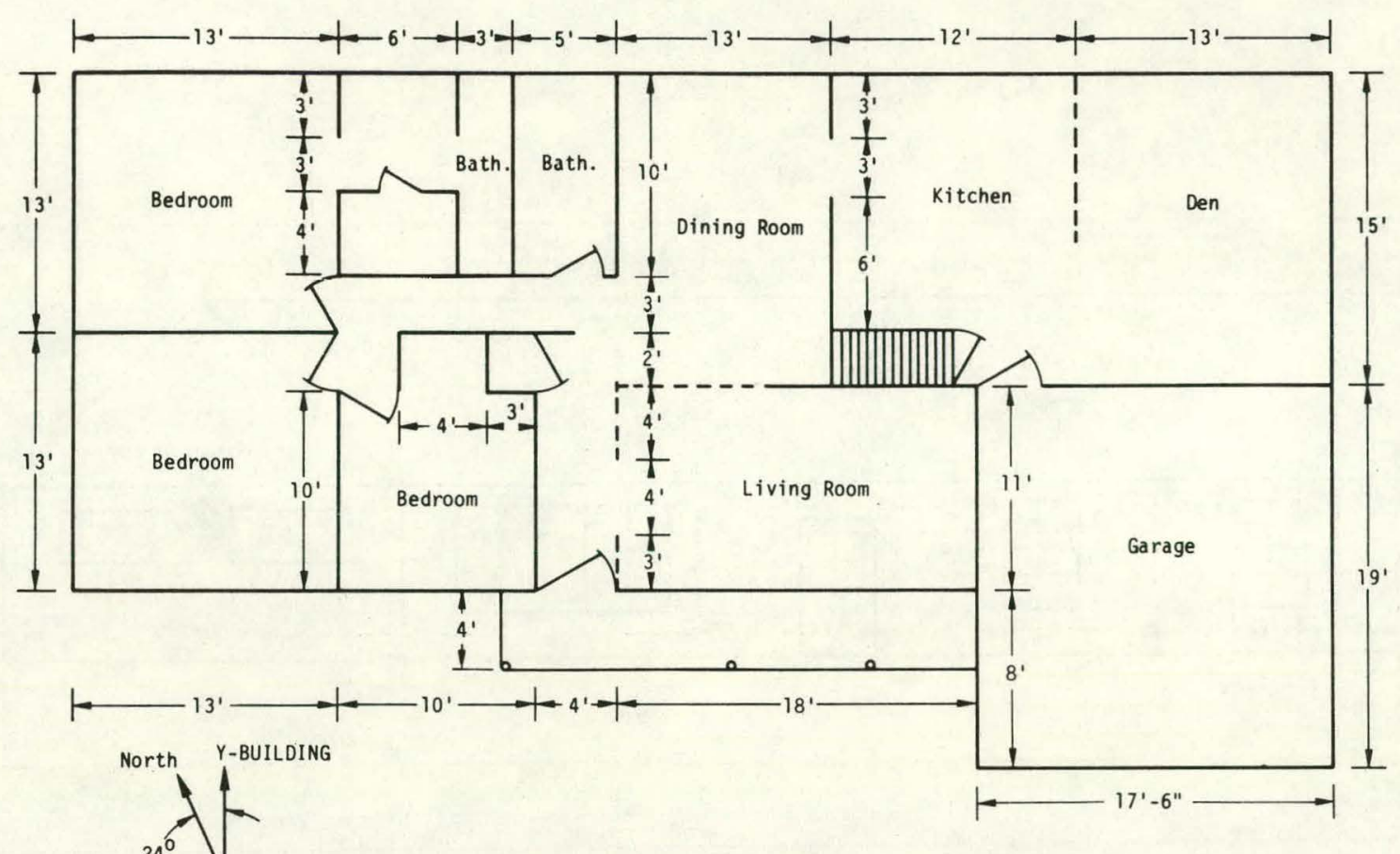

lst Floor

Floor Plan

Fig. 2. House floor plan

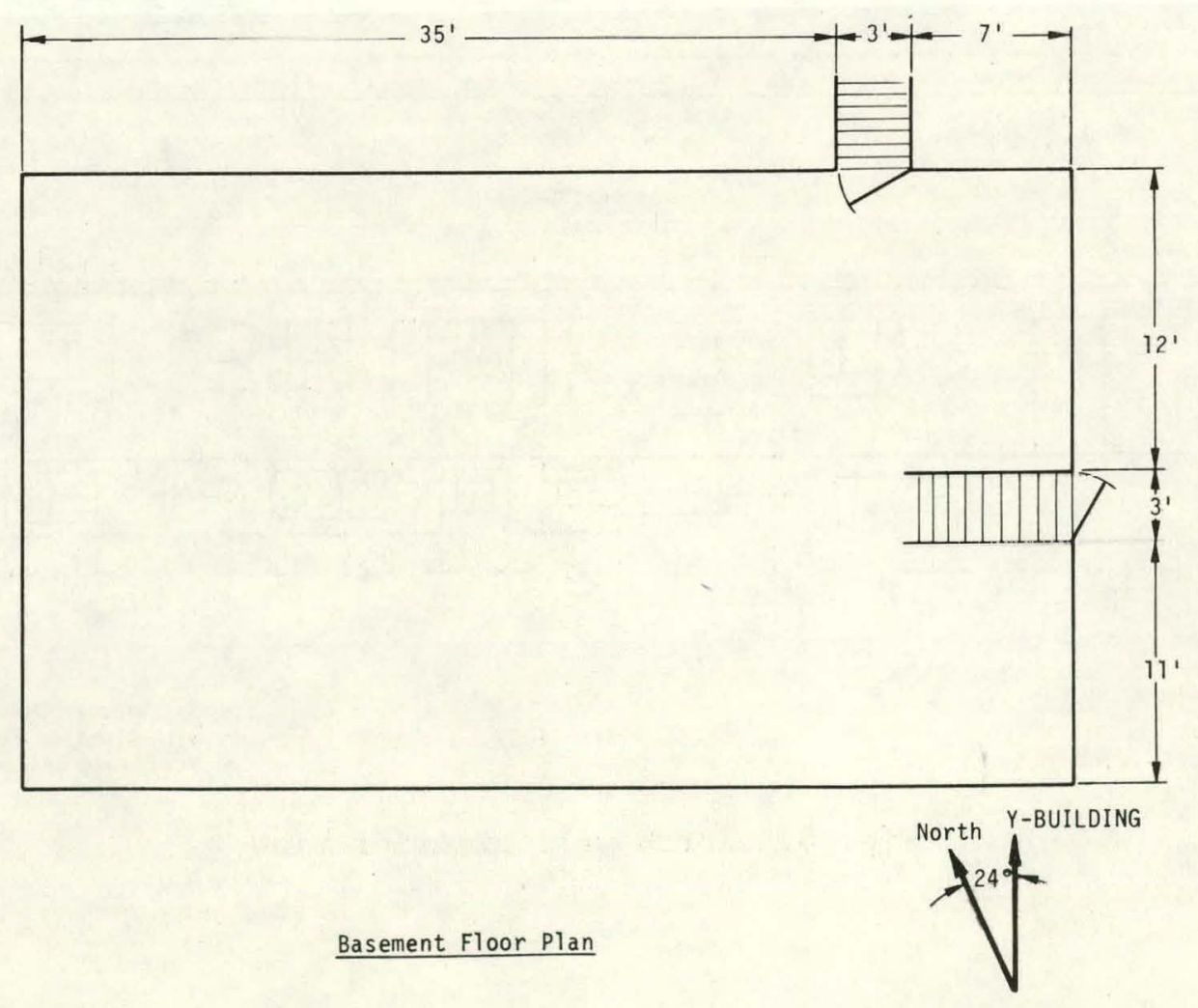

Fig. 3. Basement floor plan 
South Wall

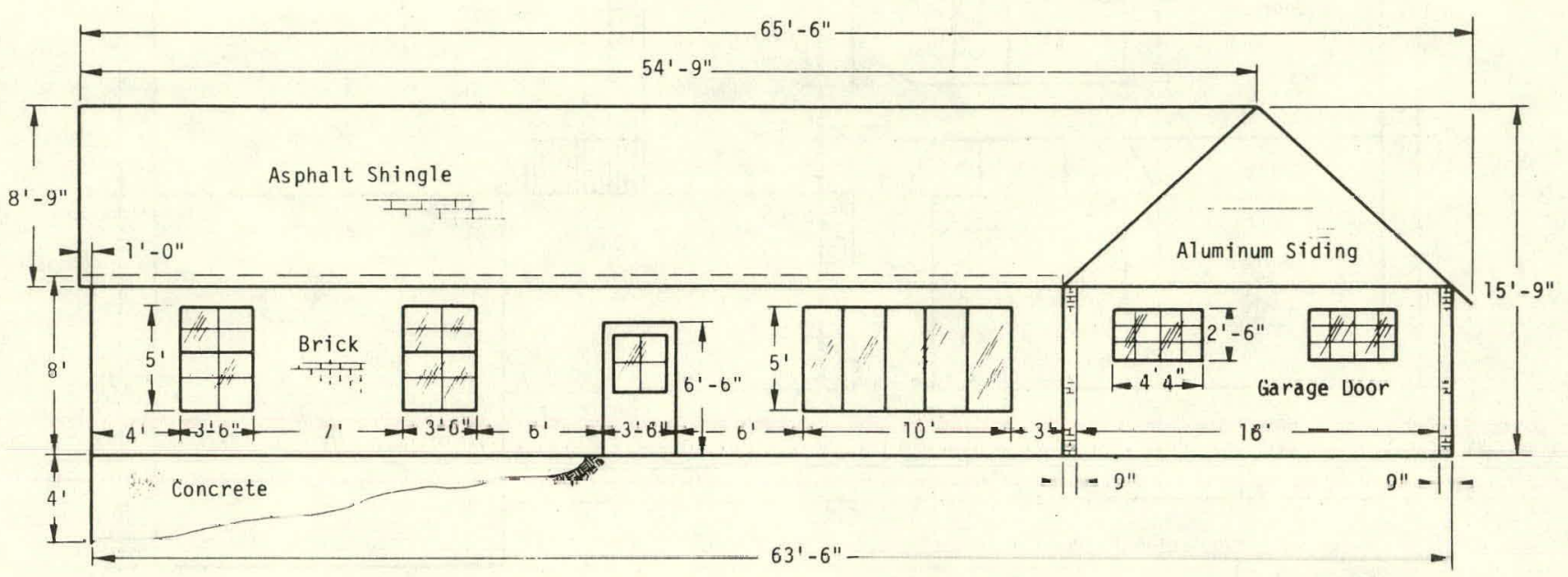

All Windows Hood rrame

Fig. 4. South wall exterior view

North Wall

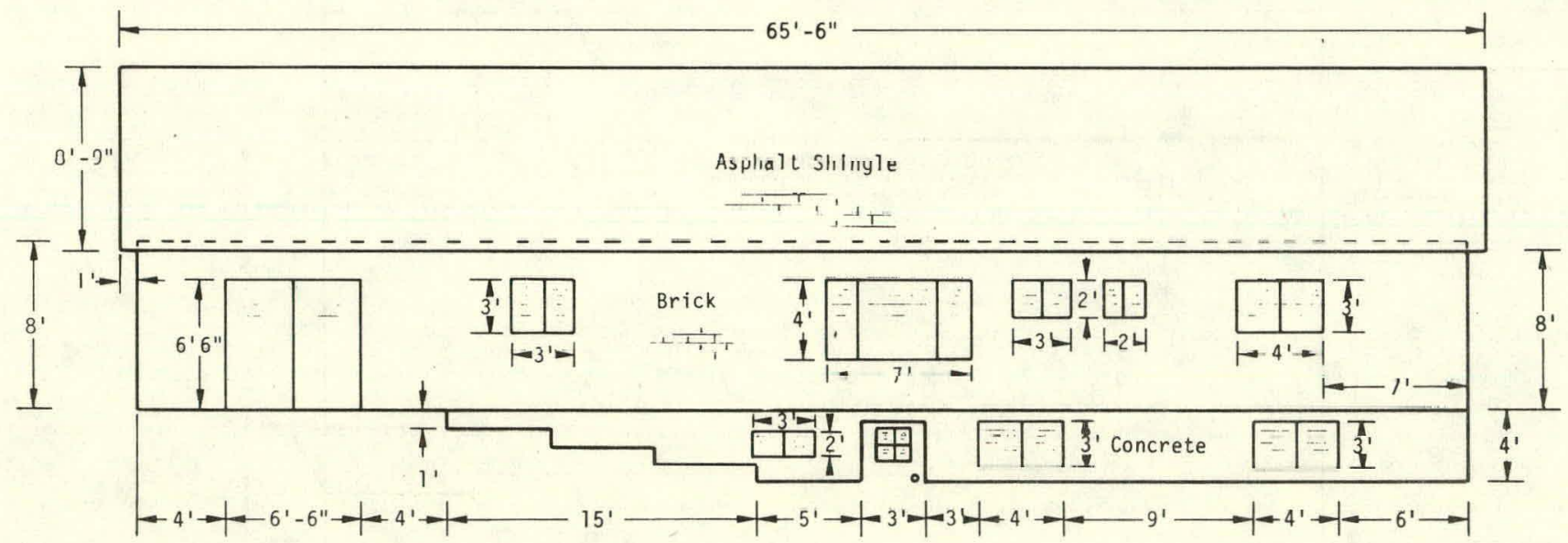

All Windows Double Glazed with Aluminum Frames except Wood Frame Basement Door

Fig. 5. North wall exterior view 


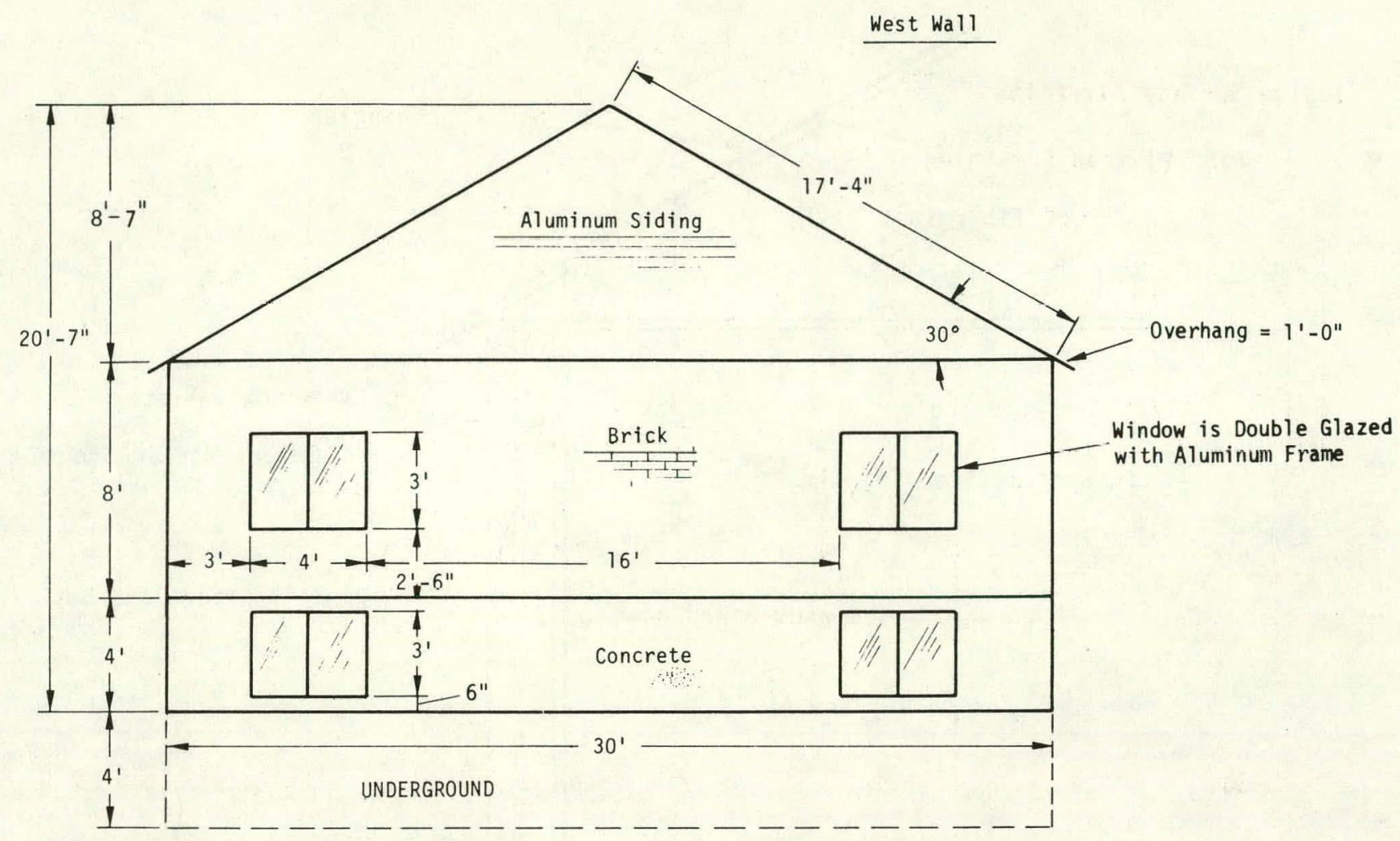

Fig. 6. West wall exterior view

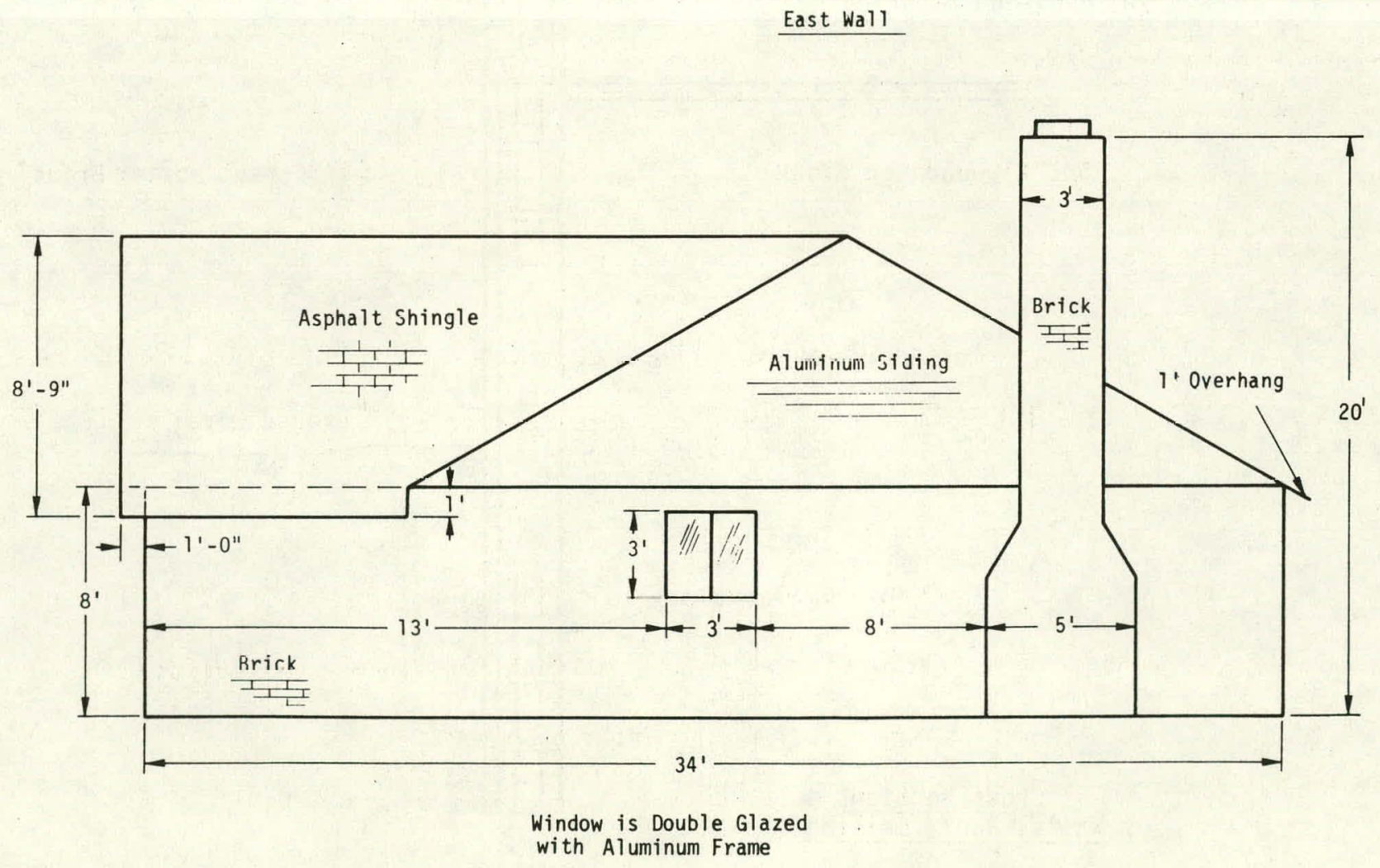

Fig. 7. East wall exterior view 


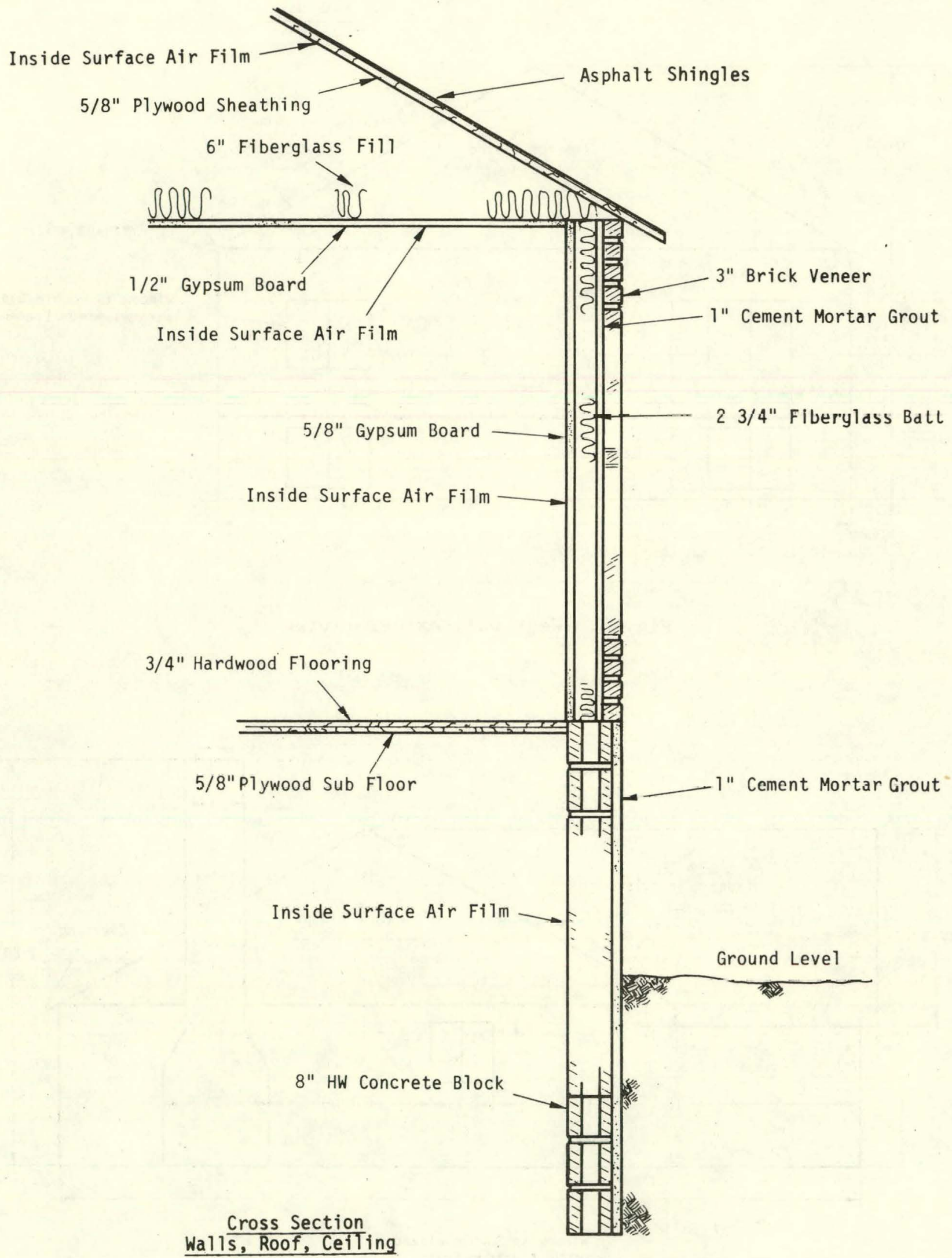

Fig. 8. House cross section view 


\section{ACTUAL ENERGY USAGE}

Utility records for the residence were studied in an effort to gain information on actual energy consumption. The Cincinnat $i$ Gas and Electric Company supplies both natural gas for space and domestic water heating and electricity for air conditioning and other appliance needs. Meter readings are taken by the company on a bimonthly basis. Interim bills are sent to the homeowner for months when the meters are not read. The charges on interim bills are estimates based on average past usage. Payment of interim bills is then subtracted from the total actual usage charge as determined by the meter readings. In this manner, the homeowner is able to break up the utility payment and is not caught having to pay a large sum every two months. In the case of the house under study, utility meter readings were performed on the average on the following dates through the year: 1) February 8; 2) April 10;3) June 10; 4) August 9; 5) October 9; and 6) December 11 . This results in the twomonth billing periods of 1) December - January; 2) February - March; 3) April - May; 4) June - July; 5) August - September; and 6) October November for one year. Since the interim bills are only estimates and therefore do not reflect actual energy usage by the residence, they are not included in the study to determine consumption.

Utility records for a period of six years were examined. The period of study ran from April 1972, when the house was first occupied by its current residents, through May 1978. Utility bills for the billing periods of December - January; June - July; and August September; 1973 were not available.

The results are summarized in a series of graphs and tables. The major factor illustrated by these graphs is that over the past years 
total energy use (gas and electricity in terms of MBTU) has tended to drop while energy costs have risen substantially. This points out the major dilemma facing most homeowners in today's world of increasing energy. prices and points toward alternative means of providing energy, such as solar applications, as a possible solution. 
TABLE 1. Residence energy consumption

YEAR BILLING PERIOD

USAGE

PAYMENT

1972

April 9 - June 9

Gas - $161 \mathrm{HcF}$

Electric - 1061 Kwh

$\$ 19.14$

$\$ 33.35$

June 10 - August 9

Gas - $69 \mathrm{HcF}$

$\$ 9.31$

Electric - $2113 \mathrm{Kwh}$

$\$ 57.87$

August $10-$ Oct. 11

Gas - 113 Hcf

$\$ 14.23$

Electric - $2636 \mathrm{Kwh}$

$\$ 65.05$

Oct. 12 - Dec. 11

Gas - 407 Hc f

$\$ 43.95$

Electric - 1433 Kwh

$\$ 42.52$

1973

\begin{tabular}{|c|c|c|c|c|}
\hline Feb. 9 - April 10 & $\begin{array}{r}\text { Gas - } \\
\text { Electric - }\end{array}$ & $\begin{array}{l}477 \\
-\quad 1392\end{array}$ & $\begin{array}{l}\text { Hcf } \\
\text { Kwh }\end{array}$ & $\begin{array}{l}\$ 51.18 \\
\$ 41.81\end{array}$ \\
\hline April 11 - June 11 & $\begin{array}{r}\text { Gas } \\
\text { Electric }\end{array}$ & $\begin{array}{r}295 \\
-\quad 1351\end{array}$ & $\begin{array}{l}\text { Hcf } \\
\text { Kwh }\end{array}$ & $\begin{array}{l}\$ 35.12 \\
\$ 40.67\end{array}$ \\
\hline June 12 - August 11 & MISSING & IG BILL & & \\
\hline August 12 - Oct. 9 & MISSINC & G BILL & & \\
\hline Oct. 10 - Dec. 10 & $\begin{array}{r}\text { Gas } \\
\text { Electric }\end{array}$ & $\begin{array}{l}-270 \\
-\quad 1603\end{array}$ & $\begin{array}{l}\text { Hcf } \\
\text { Kwh }\end{array}$ & $\begin{array}{l}\$ 34.85 \\
\$ 40.27\end{array}$ \\
\hline Dec. 11 - Feb. 8 & $\begin{array}{r}\text { Gas } \\
\text { Electric }\end{array}$ & $\begin{array}{l}-530 \\
-\quad 1560\end{array}$ & $\begin{array}{l}\text { Hcf } \\
\text { Kwh }\end{array}$ & $\begin{array}{l}\$ 66.67 \\
\$ 47.80\end{array}$ \\
\hline Feb. 9 - April 10 & $\begin{array}{r}\text { Gas } \\
\text { Electric }\end{array}$ & $\begin{array}{r}372 \\
-\quad 1364\end{array}$ & $\begin{array}{l}\text { Hcf } \\
\text { Kwh }\end{array}$ & $\begin{array}{l}\$ 48.69 \\
\$ 43.32\end{array}$ \\
\hline April 11 - June 10 & $\begin{array}{r}\text { Gas } \\
\text { Electric }\end{array}$ & $\begin{array}{r}135 \\
-1160\end{array}$ & $\begin{array}{l}\text { Hcf } \\
\text { Kwh }\end{array}$ & $\begin{array}{l}\$ 20.74 \\
\$ 38.75\end{array}$ \\
\hline June 11 - August 9 & $\begin{array}{r}\text { Gas } \\
\text { Electric }\end{array}$ & $\begin{array}{lr}-\quad 81 \\
-2820\end{array}$ & $\begin{array}{l}\text { Hcf } \\
\text { Kwh }\end{array}$ & $\begin{array}{l}\$ 13.53 \\
\$ 76.54\end{array}$ \\
\hline August $10-$ Oct. 9 & $\begin{array}{r}\text { Gas } \\
\text { Electric }\end{array}$ & $\begin{array}{r}113 \\
-2296\end{array}$ & $\begin{array}{l}\text { Hcf } \\
\text { Kwh }\end{array}$ & $\begin{array}{l}\$ 18.48 \\
\$ 69.37\end{array}$ \\
\hline ct. $10-$ Dec. 11 & $\begin{array}{r}\text { Gas } \\
\text { Electric }\end{array}$ & $\begin{array}{r}-364 \\
-\quad 1418\end{array}$ & $\begin{array}{l}\text { Hcf } \\
\text { Kwh }\end{array}$ & $\begin{array}{l}\$ 56.46 \\
\$ 54.02\end{array}$ \\
\hline
\end{tabular}

1974

Electric - 1418 
TABLE 1 (Contd.)

YEAR

BILLING PERIOD

USAGE

PAYMENT

1975

Dec. 11 -Feb. 8

Gas - 477 HCF

$\$ 75.57$

Electric - 1599 Kwh

$\$ 62.13$

Feb. 9 - April 11

Gas - $471 \mathrm{Hcf}$

$\$ 78.91$

Electric - 1425 Kwh

$\$ 55.44$

April 12 - June 9

Gas - $237 \mathrm{HcF}$

$\$ 43.97$

Electric $=1397 \mathrm{Kwh}$

$\$ 54,13$

Iume in - Aluguat R

Gax $=208 \mathrm{HuF}$

$\$ 41.87$

Electrtc $=1924$ Kwh

$\$ 35.61$

August 9 - Oct. 9

Gas - $94 \mathrm{HcF}$

$\$ 18.89$

Electric - 2614 Kwh

$\$ 84.59$

Oct. $10-$ Dec. 10

Gas - $243 \cdot \mathrm{Hcf}$

Electric - $1220 \mathrm{Kwh}$

$\$ 43.94$

$\$ 47.94$

1976

Dec. 11 - Feb. 9

Gas - $586 \mathrm{Hcf}$

$\$ 106.51$

Electric - 1704 Kwh

\$. 64.52

Feb: 10 - April 9

Gas - 288 Hcf

$\$ 54.20$

Electric - $1229 \mathrm{Kwh}$

$\$ 49.60$

April 10 - June 10

Gas - $128 \mathrm{HcE}$

$\$ 25.41$

Electric - $1108 \mathrm{Kwh}$

$\$ 44.77$

June 11 - August 10

Gas - 91 Hcf

$\$ 19.38$

Electric - $3023 \mathrm{Kwh}$

$\$ 95.05$

August 11 - Oct. 8

Gas - $73 \mathrm{Hcf}$

$\$ 17.56$

Electric - 1835 Kwh

$\$ 68.75$

Oct. 9 -Dec. 9

Gas - 418 Hcf

$\$ 89.03$

Electric - 1432 Kwh

$\$ 54.46$

1977

Dec. 10 -Feb. 8

Gas - 640 Hcf

$\$ 143.41$

Electric - $1600 \mathrm{Kwh}$.

$\$ 59.66$

Feb. 9 -April 12

Gas - 328 Hcf

$\$ 77.40$

Electric - 1337 Kwh

$\$ 52.31$

April 13 - June 9

Gas - $88 \mathrm{Hcf}$

$\$ 23.90$

Electric - 1649 Kwh

$\$ 61.45$

June 10 - August 10

Gas - $82 \mathrm{Hcf}$

$\$ 23.07$

Electric - 3370 Kwh

$\$ 106.25$ 
TABLE 1 (Contd.)

YEAR BILLING PERIOD

USAGE

PAYMENT

1977

August $11-0 c t .7$

Gas - 60 Hcf
Electric - 1901 Kwh

$\$ 19.17$

$\$ 70.66$

Oct. 8 - Dec. 10

Gas - $320 \mathrm{Hcf}$

$\$ 85.90$

Electric - 1465 Kwh

$\$ 57.04$

1978

Dec. 11 -Feb. 9

Gas - 595 Hcf

$\$ 152.78$

Electric - 1902 Kwh

$\$ 74.09$

Feb. 10 - April 12

Gas - $407 \mathrm{Hcf}$

$\$ 109.53$

Electric - 1431 Kwh

$\$ 64.35$

April 13 - June 12

Gas - $138 \mathrm{HcF}$

$\$ 40.92$

Electric - 1164 Kwh

$\$ 50.93$

TOTAL USAGE

GAS-100 cubic feet $=100,000$ BTU

ELECTRICITY - $1 \mathrm{Kwh}=3412 \mathrm{BTU}$

1974

GAS $-1595 \mathrm{Hcf} \times 100,000 \mathrm{BTU} / \mathrm{Hcf}=159.50 \mathrm{MBTU}$
ELE $-10,618 \mathrm{Kwh} \times 3412 \mathrm{BTU} / \mathrm{Kwh}=\frac{36.73}{196.23} \mathrm{MBTU}$

1975

GAS - $1730 \mathrm{Hcf} \times 100,000 \mathrm{BTU} / \mathrm{Hcf}=173.00 \mathrm{MBTU}$

ELE $-10,179 \mathrm{Kwh} \times 3412 \mathrm{BTU} / \mathrm{Kwh}=\frac{34.73 \mathrm{MBTU}}{207.73 \mathrm{MBTU}}$

1976

GAS - $1584 \mathrm{Hcf} \times 100,000 \mathrm{BTU} / \mathrm{HcF}=158.40 \mathrm{MBTU}$

ELE $-10,331 \mathrm{Kwh} \times 3412 \mathrm{BTU} / \mathrm{Kwh}=\frac{35.25 \mathrm{MBTU}}{193.65 \mathrm{MBTU}}$

1977

GAS $-1518 \mathrm{HCF} \times 100,000 \mathrm{BTU} / \mathrm{Hcf}=151.80 \mathrm{MBTU}$

ELE $-11,322 \mathrm{kwh} \times 3412 \mathrm{BTU} / \mathrm{Kwh}=\frac{38.63}{190.43 \mathrm{MBTU}}$

1978

GAS $-1542 \mathrm{Hcf} \times 100,000 \mathrm{BTU} / \mathrm{Hcf}=154.20 \mathrm{MBTU}$

ELE $-10,418 \mathrm{Kwh} \times 3412 \mathrm{BTU} / \mathrm{Kwh}=\frac{35.54 \mathrm{MBTU}}{189.74} \mathrm{MBTU}$ 
TABLE 2. Fuel rates

YEAR

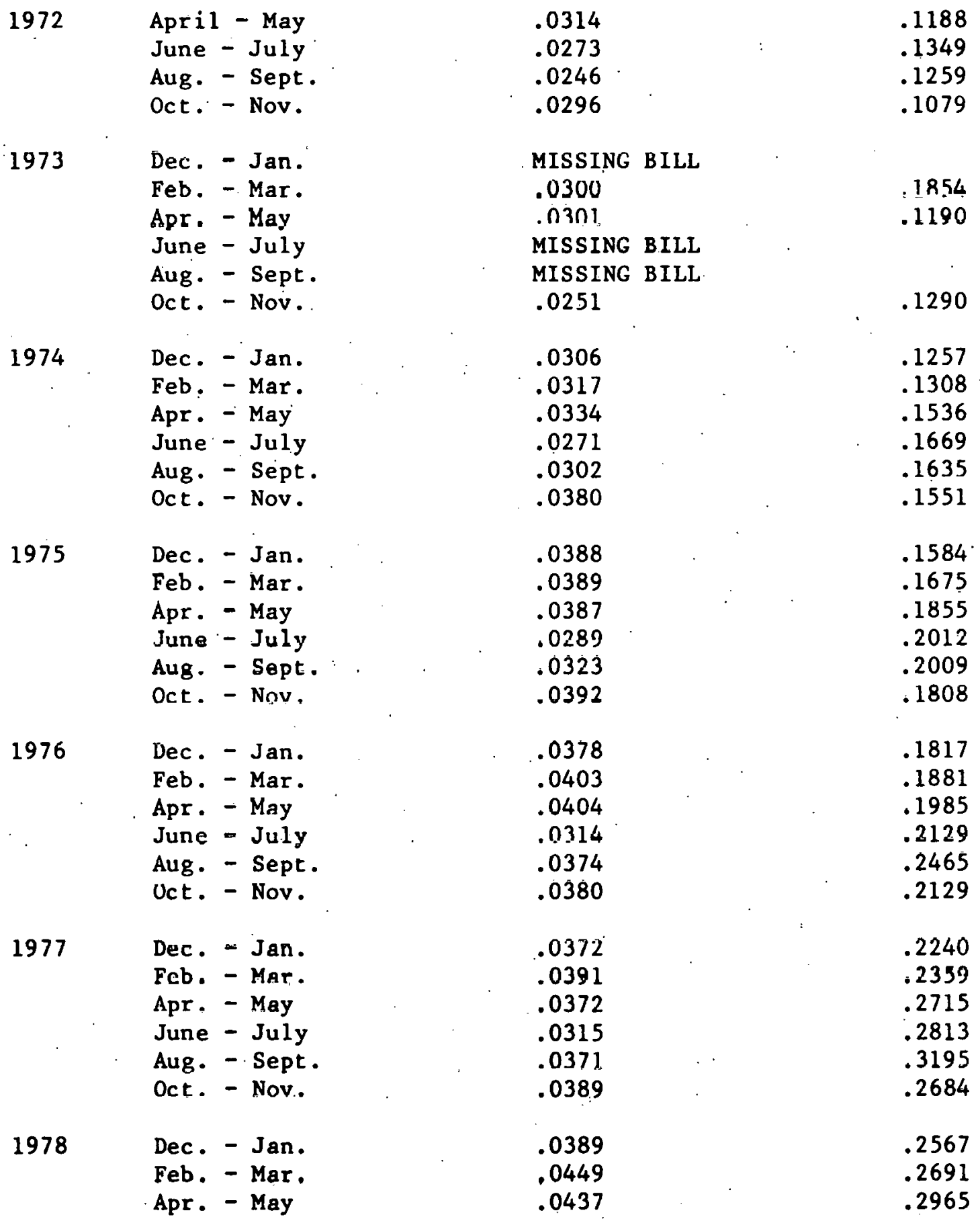




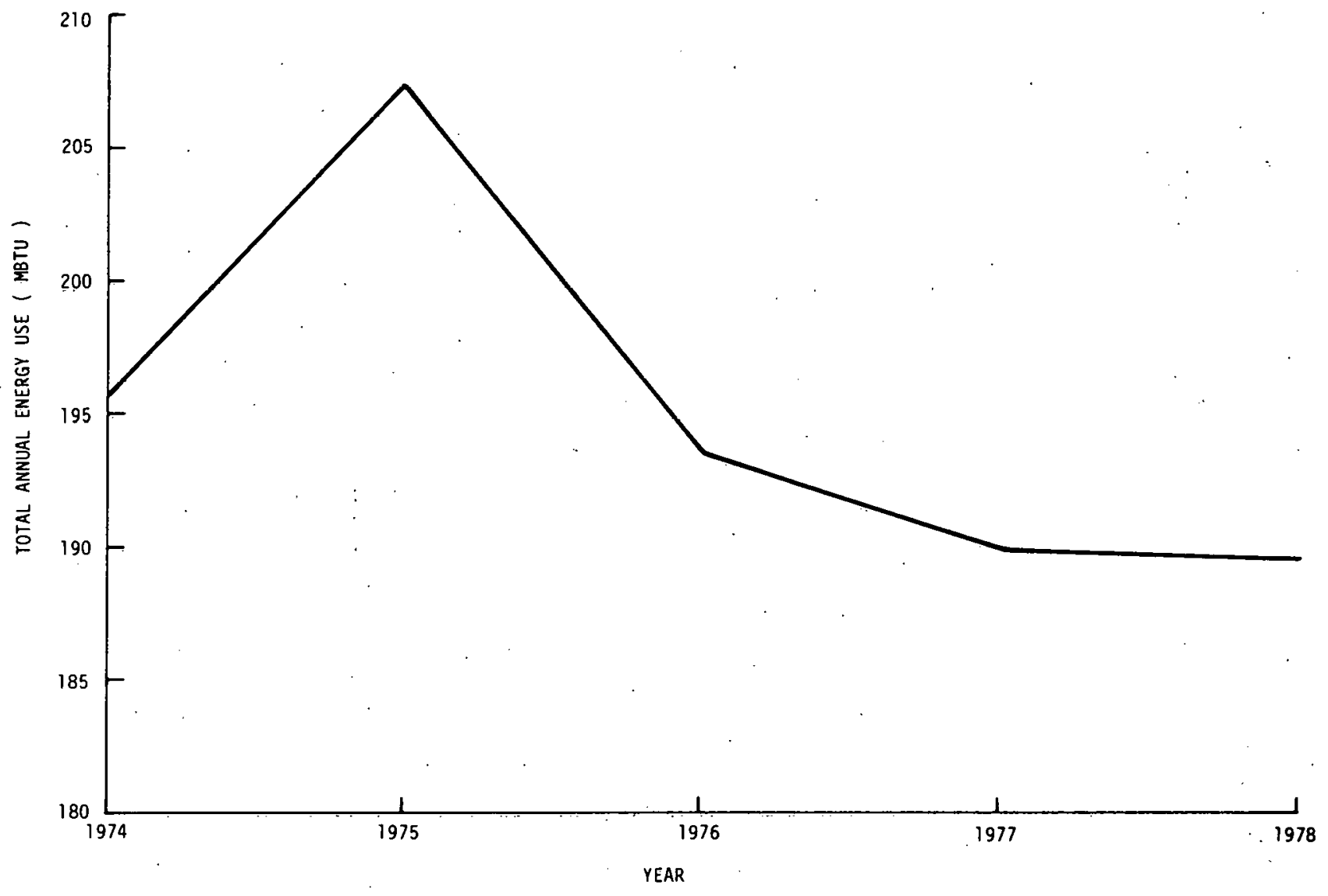

Fig. 9. Total annual energy use (MBTU) vs time. Actual total annual energy consumption was determined from utility records. One cubic foot of natural gas yields approximately $1000 \mathrm{BTU}$. and one Kwh of electricity equals about 3412 BTU. From these values, total house energy use was obtained for the years 1974-1978. Only partial data for the year 1972 and missing bills from 1973 forced the omission of parts of these years from the total.

Except for the year 1.975, the trend is one of decreasing annual energy corisumption. Values plotted are 195.73 MBTU in 1974, $207.73 \mathrm{MBTU}$ in $1975,193.65 \mathrm{MBTU}$ in $1976,190.43 \mathrm{MBTU}$ in 1977, and 189.74 MBTU in 1978. This represents a $3.0 \%$ decrease in usage from 1974 through 1978 and an $8.6 \%$ decrease in energy use from the peak in 1975. Although these figures indicate a drop in household energy demand, the total annual tuel bill is on the rise, showing the increase in fuel costs over the past few years. 


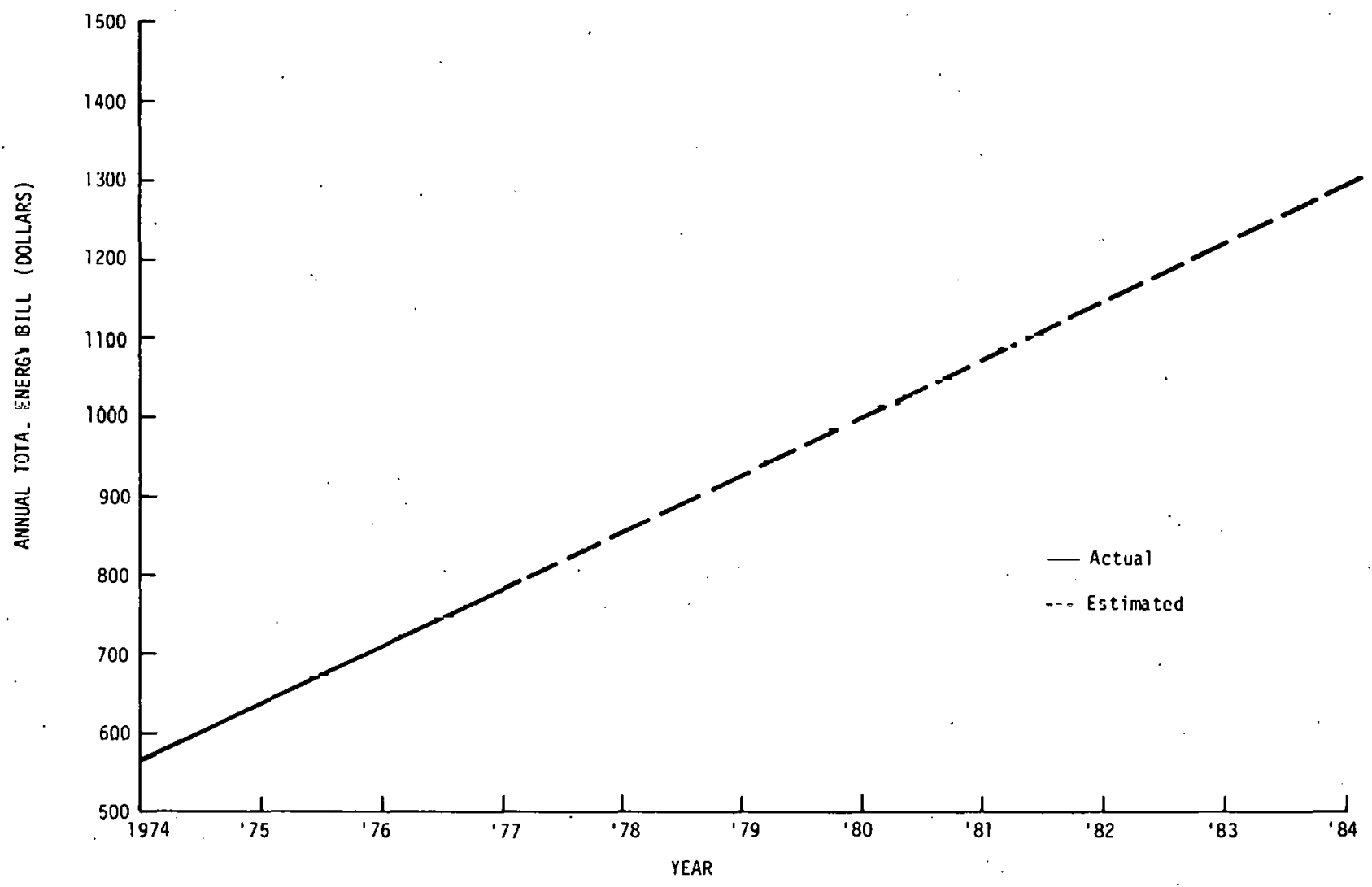

Fig. 10. Annual total energy bill (\$) vs time. The bimonthly gas and eleclilic bills have been added tu ubtaln a tutal eniergy bill for a particular entire year. Complete annual utility records for the residence are available only for the years 1974 through 1979. Missing records from 1973 and only partial annual records from 1972 and 1978 prohibit the plotting of these years on the graph. However, it can be seen from the data available that total annual enèrgy chärges have been stèadily jucréasing ovcr the past four years. Charges range from a total of $\$ 554.36$ in $1974, \$ 663.05$ in $1975, \$ 689.24$ in 1976 , to $\$ 780.32$ in 1977. This averages out to a $12.23 \%$ annual increase in energy bills rangling from a high of $19.6 \%$ annual increase from 1974 to 1975 , to a $10 \bar{w}$ of $3.9 \%$ annual increase from 1976 to 1977 . A straight line approximation through the year 1984 has been carried out based on this plot. If this projection is valid, total annual energy charges in that year could be around $\$ 1300$. 


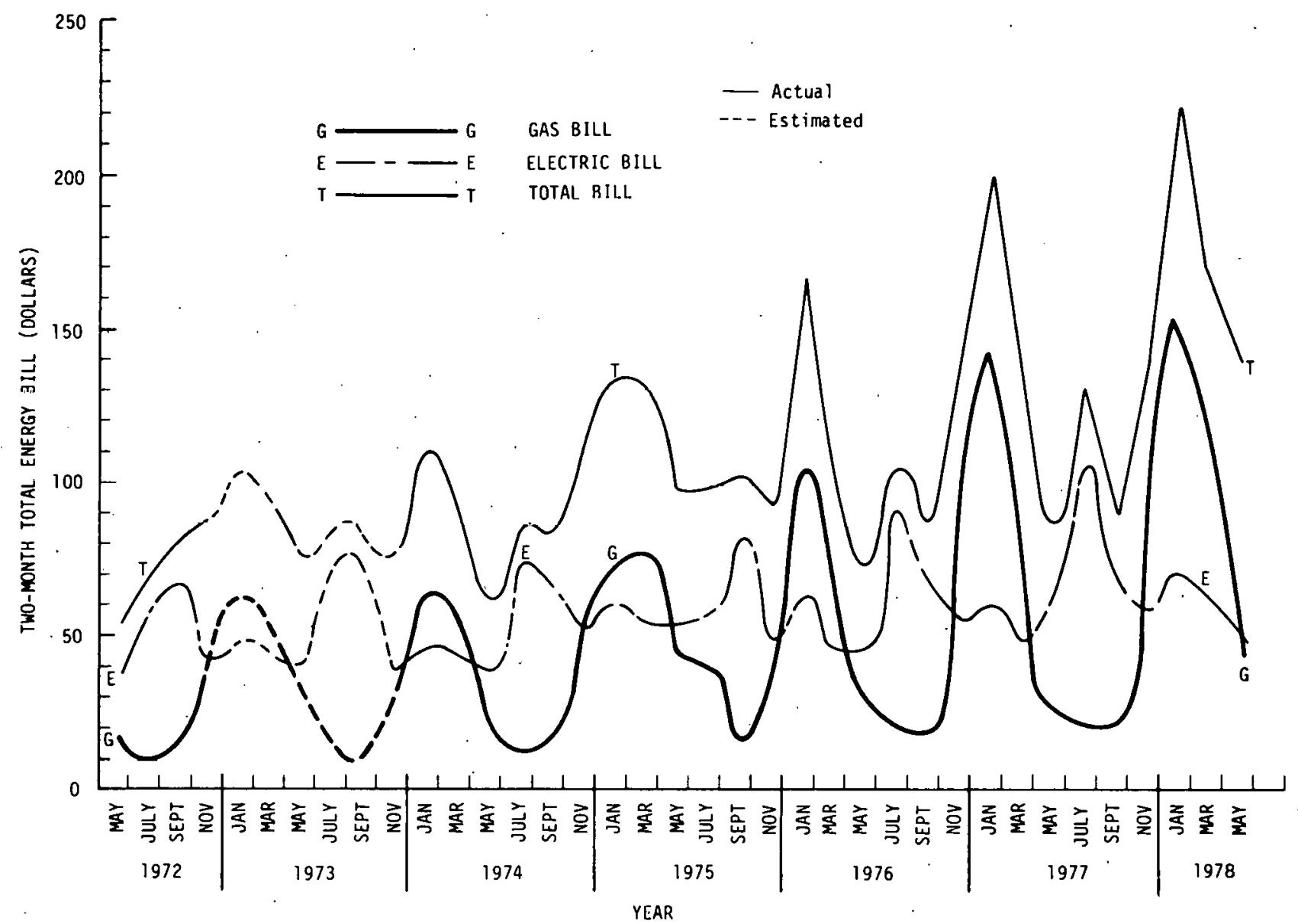

Fig. 11. Two-month total energy bill (\$) vs time. Utility (gas and electric) meter readings are taken every two months. Interim bills are sent to homeowners for months when the meters are not read to help break up total bimonthly utility bills. Charges for interim months are. estimated based on past usage. Since this is only an estimate, the interim charge does not reflect actual usage. For this reason this graph plots the two-month total energy bill against the years of occupancy. Also plotted on the graph are the individual gas and electric charges which make up the total bill. Missing records are estimated for the periods of December-January; June-July; and August-September 1973.

The graph shows a gradual rise in the two-month utility charges from the period of May 1972 through May 1978. Especially evident are three total energy bill peaks of $\$ 171.03, \$ 203.07$, and $\$ 226.87$ for the months of December-January 1976; December-January 1977; and December-January 1978, respectively. Undoubtedly, this reflects the severe weather conditions plaguing the region during these periods. It can be seen that gas charges represent the major portion of the total bill during the winter months due to home heating demands. Electric charges constitute the major fraction of the total bill during the summer months as a result of high air conditioning loads. Total energy charges are lowest during the opring and autumn months since outdoor ambient conditions require little home energy input in terms of heat or air conditioning. 


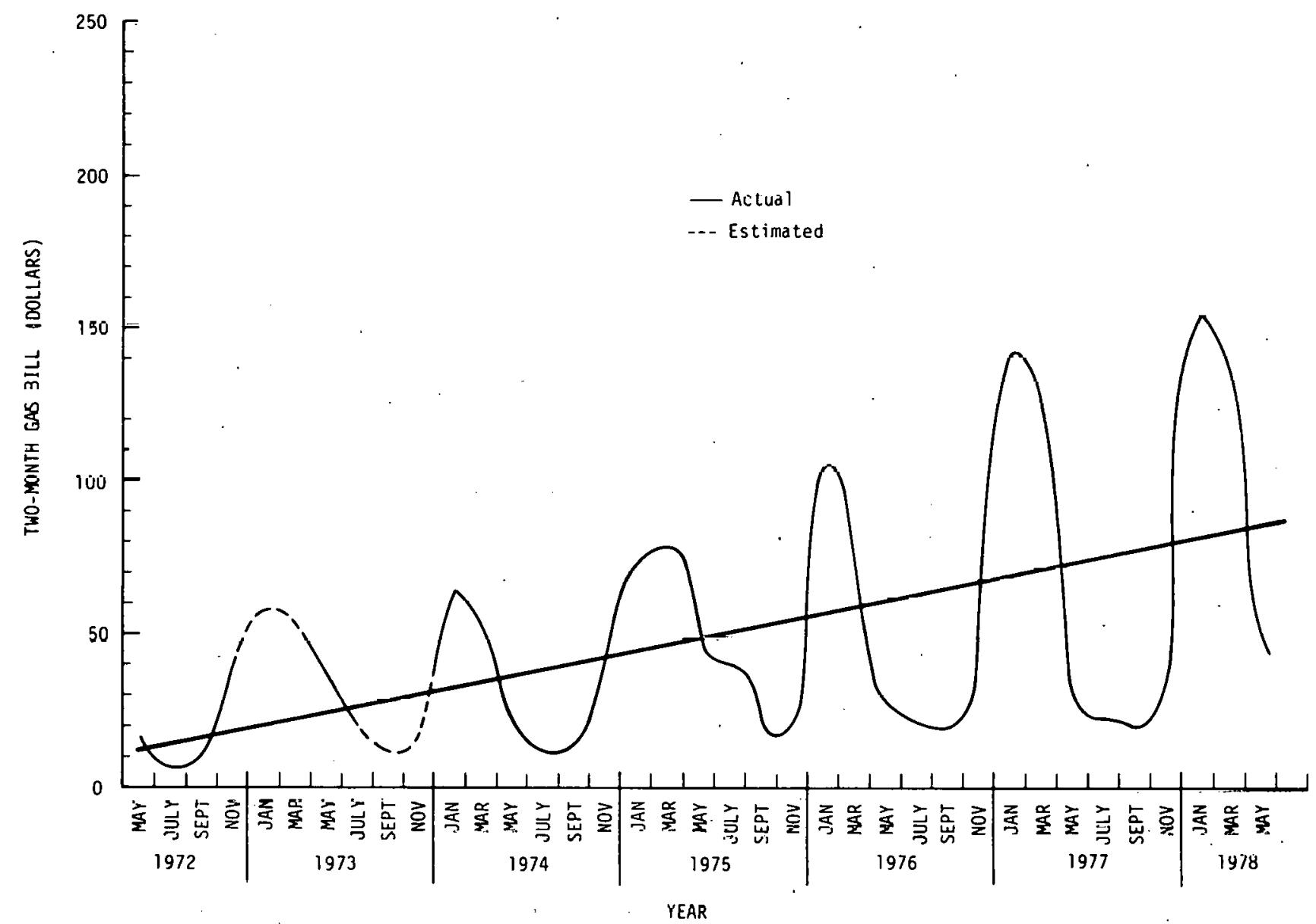

Fig. 12. Two-month gas bill (\$) vs time, This graph illustrates the annual cycling of the natural gas energy charges for the period of home occupancy. As mentioned previnusly, nne ran see that gas charges are low in the summer munths when only domestic water heating contributes to the gas demand. Charges are high in the winter months when gas is also used for home heating. Once again the long-term trend is toward an increasing energy charge as illustrated by the straight line increase. The three peaks for the winters of 19751976, 1976-1977, and 1977-1978 again stand out with gas charges of $\$ 106.51$, $\$ 143.41$, and $\$ 152.78$ for the December-January bills of those years, respectively. The summer water heating costs average $\$ 21.90$ for the two-month periods of April-May, June-July, and August-September over six years. 


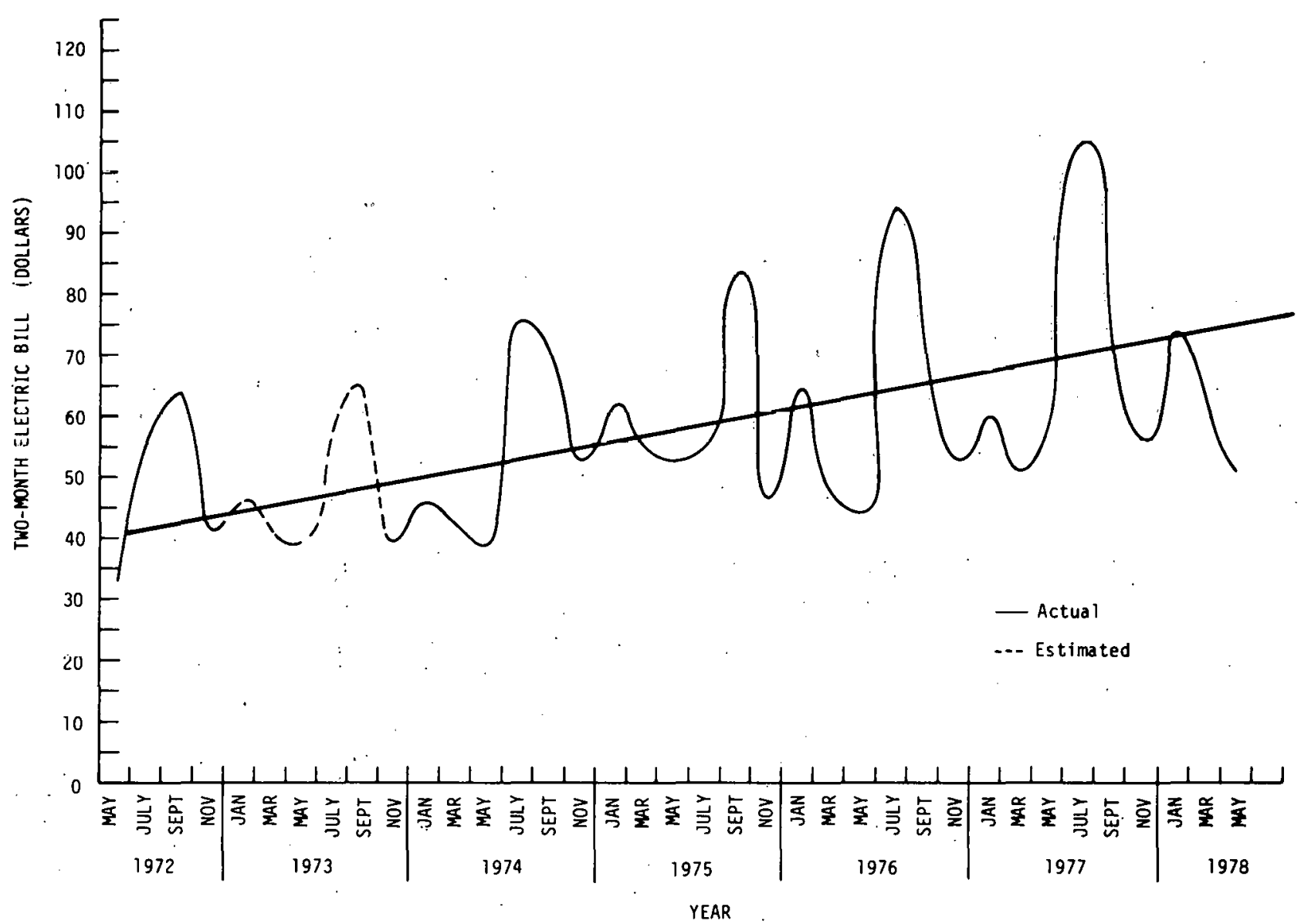

Fig. 13. Two-month electric bill (\$) vs time. Similar to the previous graph, this plot illustrates the annual cycling of energy costs, in this case electricity charges. This plot, however, is slightly more complicated than the gas costs vs time graph. Electric bills seem to have two annual peaks. The main peak occurs during the summer season and coincides with peak electrical air conditioning demand. The smaller peak occurs in the winter months and undoubtedly represents electrical usage from the furnace blower and lighting due to fewer daylight hours. It is surprising that blower and lighting use during the winter would be significant enough to show up on electrical bill. records but this seems to be the case. As with the two-month gas hill vs time graph (Fig, 12), the longterm trend is toward increasing electrical costs. 


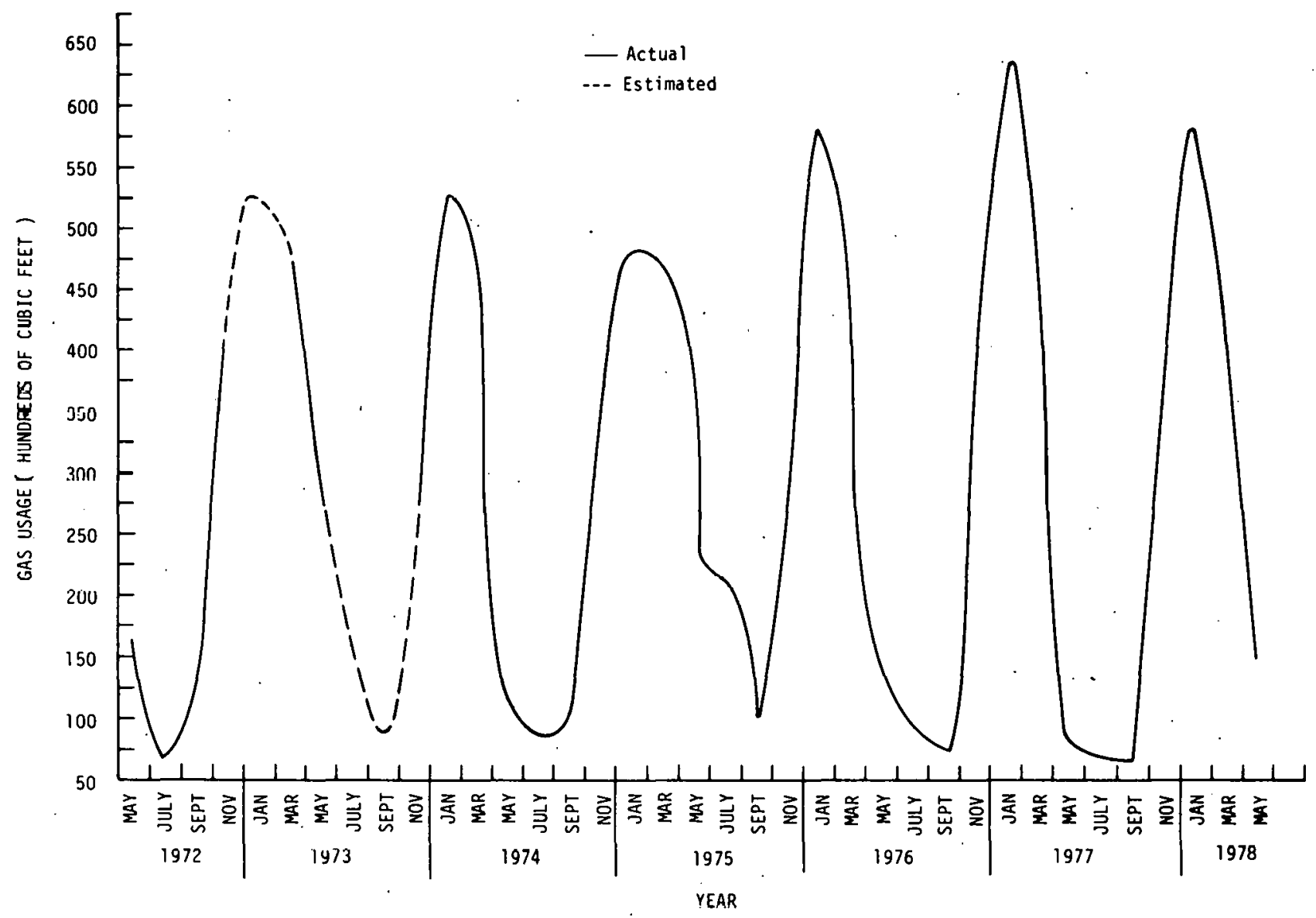

Fig. 14. Gas usage (hundreds of cubic feet) vs time. The gas usage vs time graph nearly mirrors the gas bill vs time graph but for one obvious exception. Gas usage is high during the wintcr homc heating season and low during. the summer season when only domestic water heating contributes to gas consumption. The difference between this gas usage graph and the gas bill graph io onc of slope. Cas usage seems to have remained fairly consistent for the six-year period of occupancy with the possible exception of the last three winters when gas consumption was slightly higher due to colder weather conditions. However, the gas bill graph (Fig. 12) shows an increase in gas charges throughout the six-year occupancy period. So even though gas usage has remained constant, gas costs have risen over the past six years. 


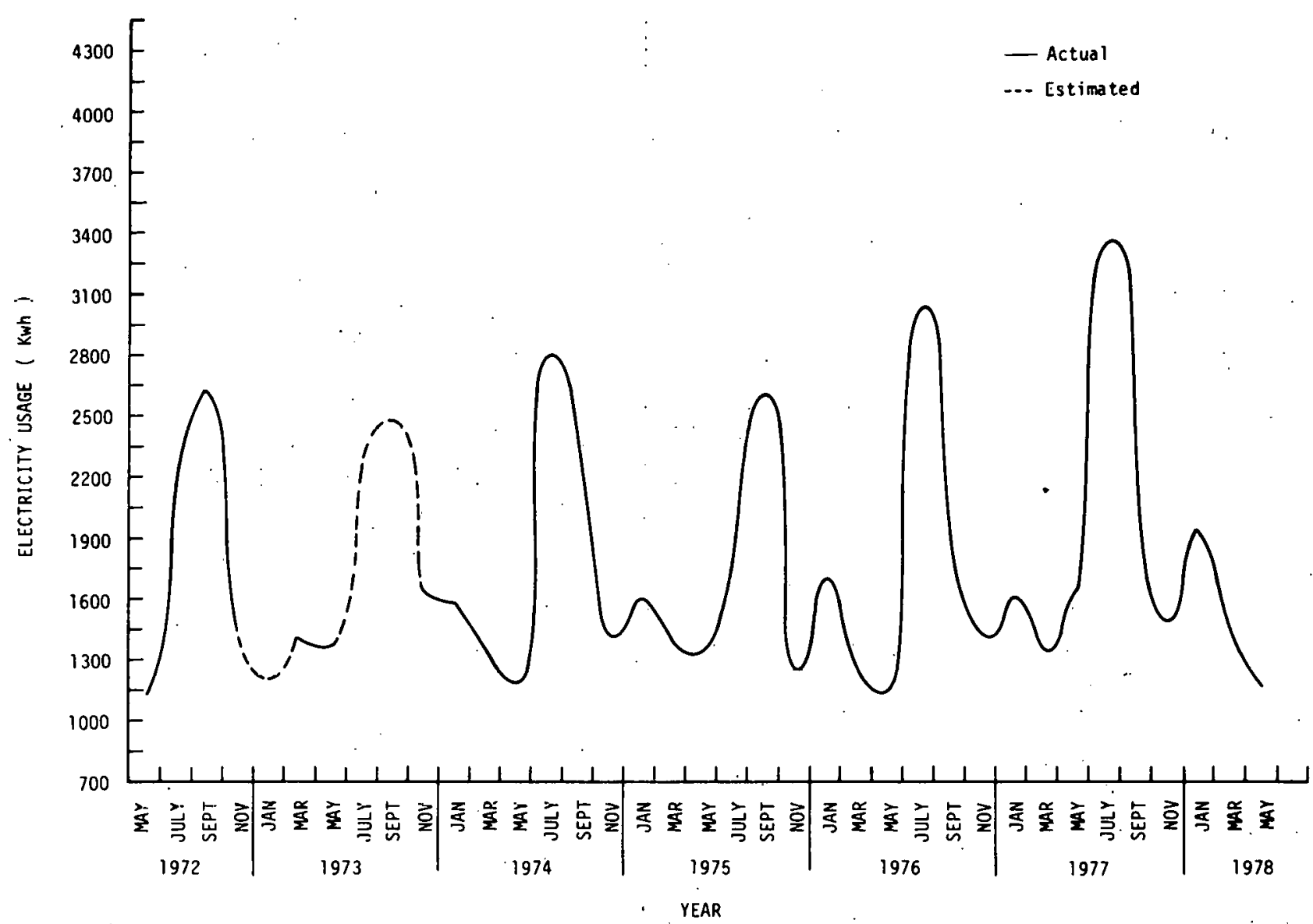

Fig. 15. Electricity usage (Kwh) vs time. The electricity usage vs time graph shows a similar pattern to the gas usage vs time graph (Fig. 14) in that the energy usage has remained fairly consistent over time. As noted previously with the electric bill graph, there are two distinct anmual peaks. The higher peak occurring during the summer season coincides with high electrical air conditioning demand. The smaller peak occurs during the winter heating season and represents the usage for the furnace's electrical blower and lighting. Low points in electrical usage occur in spring and fall months when there is a small home heating and cooling requirement and may be interpreted as the baseload electrical demand from appliances. The summer peaks average 2892.6 Kwh per two-month billing period. Spring and fall lows average 1204.5 Kwli per two-month billing period. 


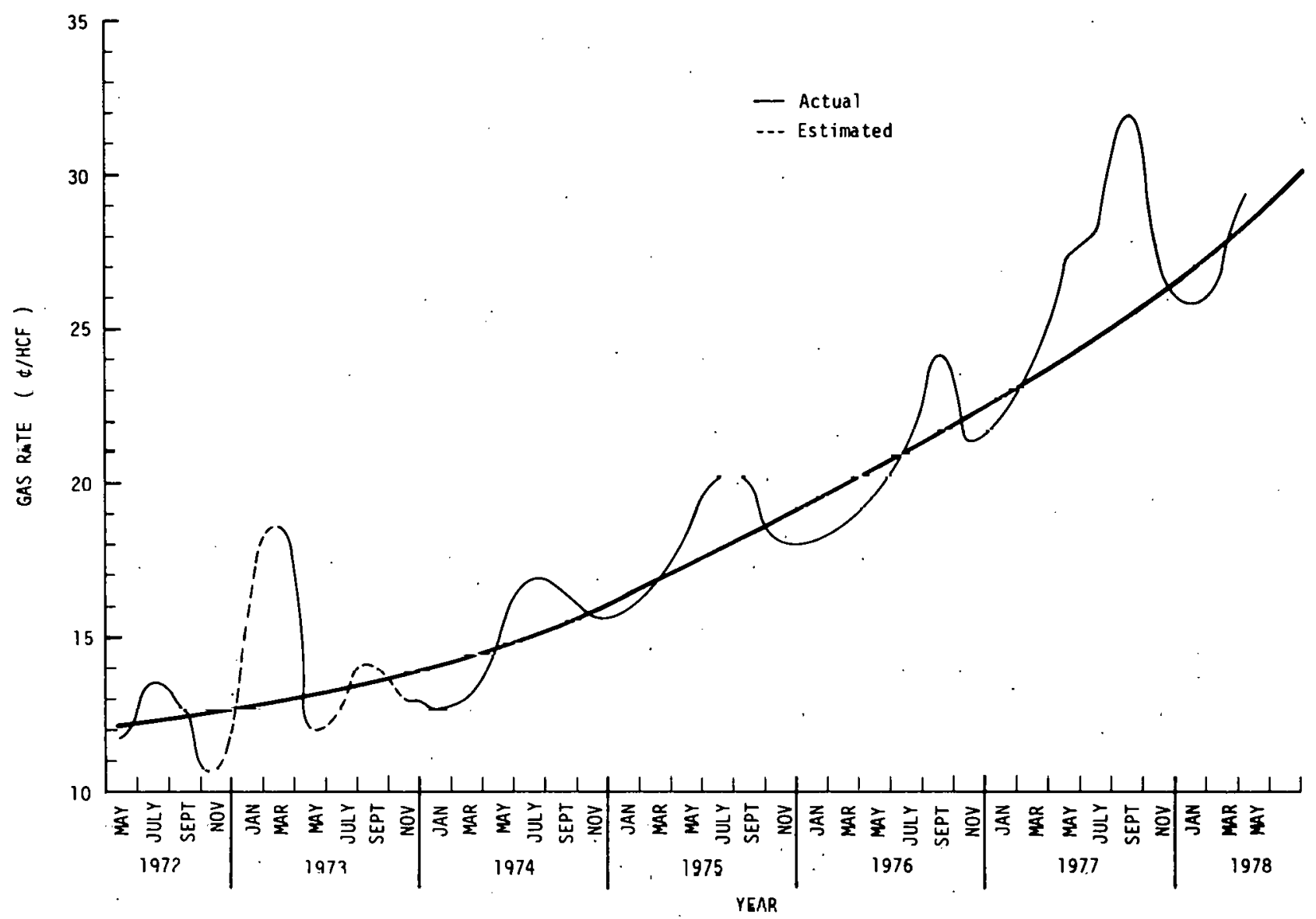

Fig. 16. Gas rate ( $c / \mathrm{Hcf})$ vs time. As it was noted earlier, gas costs rose during the six-year period of study while gas consumption remained fairly consistent. This would indicate an increase in gas rates. Gas rates for a billing period were determined by dividing gas costs by gas usage. This graph illustrates the rioing of gae rates over time. An interesting pattern does appear. Gas rates seem to peak during the summer months when usage is low. The rates are at a low point during the winter months when usage is at a high. This suggests a pricing structure incorporated by the utility company so as to even out profits throughout the year. High rates at times of low demand and low rates during periods of high demand guarantee the utility a steady income over the year. It should be also noted that the increase in rates over time is not a straight line, but shows an upward curve. Gas rates are increasing at an increasing rate. Actual calculated rates range from a low of $10.79 \mathrm{c} / \mathrm{Hcf}$ in OctoberNovember 1972 to a high of $31.95 \mathrm{c} / \mathrm{Hcf}$ in August-September 1977. The average rate of increase is about $15 \%$ per year. 


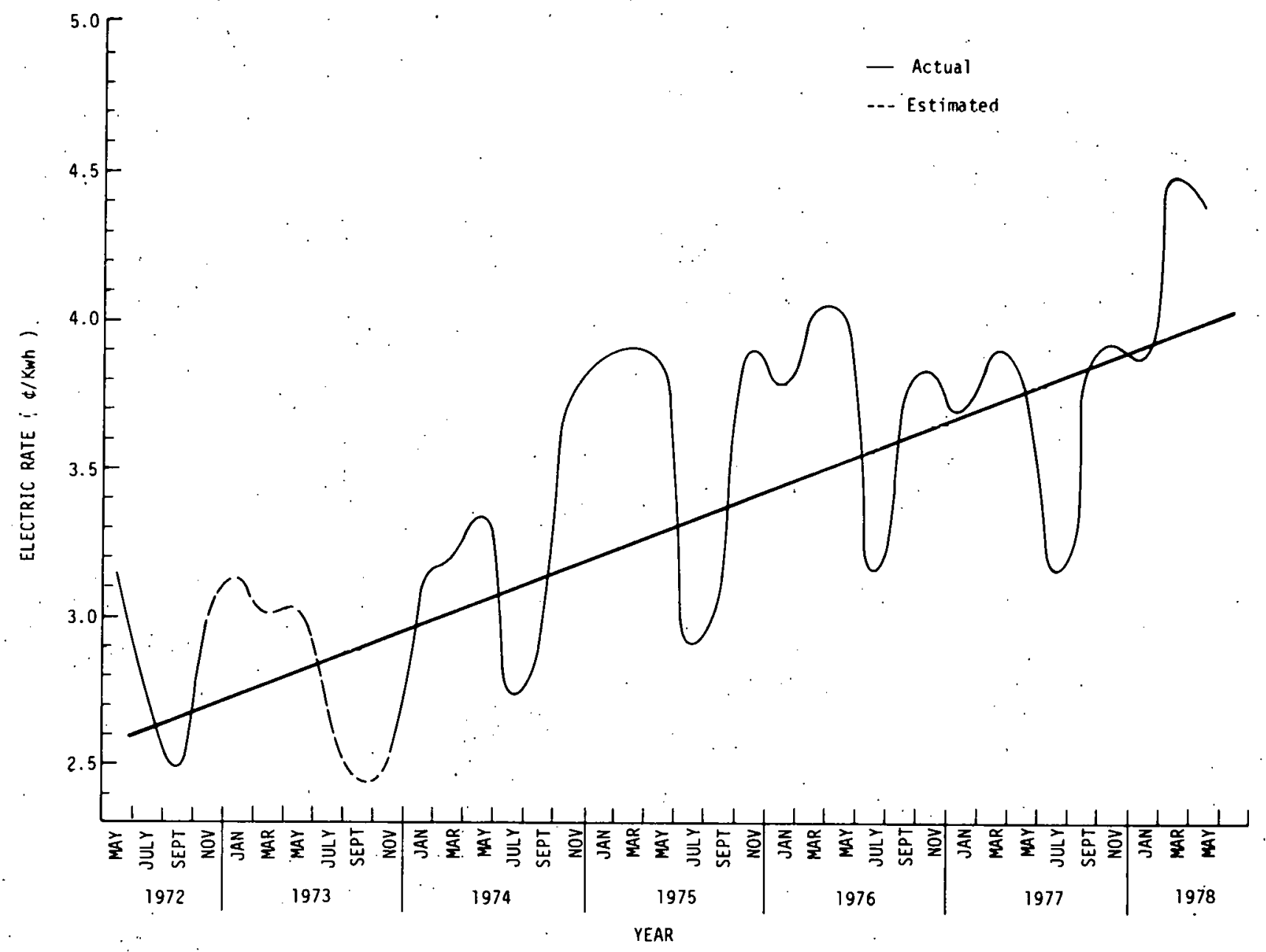

Fig. 17. Electric rate (c/Kwh) vs time. Electric rates were calculated. the same way as gas rates, electric costs divided by electric usage. This rate pattern is similar to the pattern for gas rates. Electric rates are high during off season periods when usage is low and rates are low during peak periods when consumption is high. As with gas rates, this pricing structure allows the utility to even out their income over the year. Also, as with gas rates; the electric rates are on the rise. However, the rate of increase seems to be more of a steady straight line. Electric rates range from a low of $2.467 \mathrm{c} / \mathrm{kwh}$ in August-September 1972 to a high of $4.496 \mathrm{c} / \mathrm{Kwh}$ in FebruaryMarch of 1978. This averages out to be a $0.24 \mathrm{c} / \mathrm{Kwh} / \mathrm{year}$ increase in electric rates. 


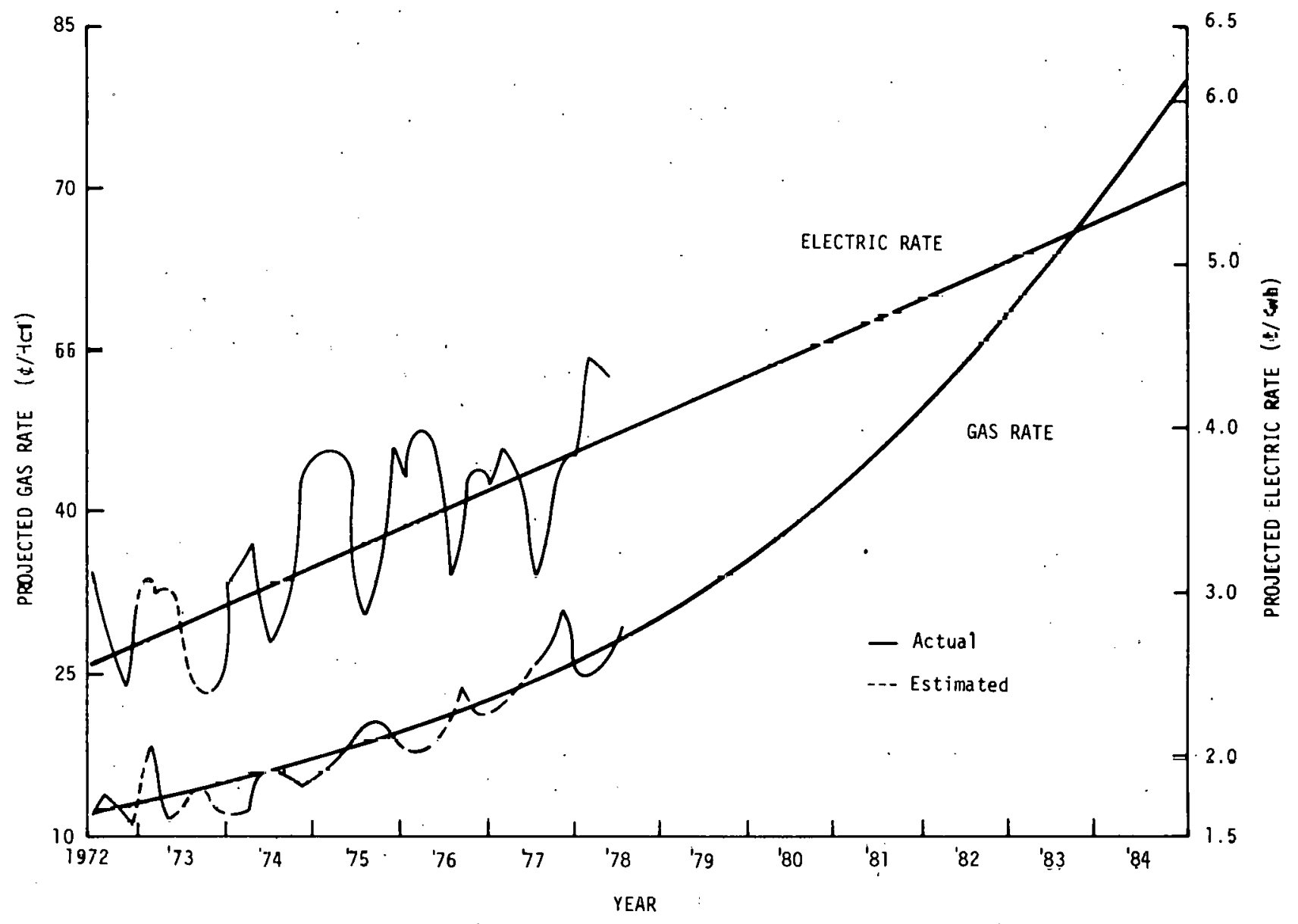

.Fig. 18. Projected gas rate (c/Hcf) and projected electric rate ( $c / \mathrm{I}\left(w \mathrm{~L}_{1}\right)$ vs Llme. Th1s graph projects, at current levels of increase, the gas and electric rates through the year 1984. The exponential gas rate increase is much more noticeable in this diagram. At these levels of increase, gae rates would be close to $80 \mathrm{c} / \mathrm{Hcf}$ and electric rates would be around $5.5 \mathrm{c} / \mathrm{Kwh}$ in 1984. " of course, these are only estimates based on very short term history. 


\section{HOUSEHOLD SCHEDULES}

Household schedules do affect residential energy consumption to a degree. In an effort to obtain as accurate a model as possible, it is necessary to estimate the various schedules pertaining to the study household. Occupancy schedules are assumed to be at a $50 \%$ level during the normal weekday working hours of 8 a.m. to 5 p.m. and $100 \%$ during the remaining weekday hours as well as on weekends. There are of course periods when the house is unoccupied and periods when more people are present. Therefore, it is impossible to determine precisely the occupancy characteristics over the course of an entire year. An average occupancy schedule that could be applied throughout the year is thus utilized. People occupying a space can contribute significant amounts of heat to the space which may affect the building heating or cooling load accordingly. Values can range from 295 BTU/HR given off by a child seated at rest to approximately $1500 \mathrm{BTU} / \mathrm{HR}$ for an adult male performing heavy work. Taking into account the time periods when various levels of activity are performed, (up to eight hours per day of sleeping at a low rate of heat production, daily activities at a moderate rate, and infrequent periods of heavy activity) an average of $400 \mathrm{BTU} / \mathrm{HR} /$ person is used in the modeling procedure.

Lighting schedules can also be significant in terms of contributing to household energy supply and demand. As much as $90 \%$ of the electricity used for an incandescent light fixture may be converted to heat and therefore released to the surrounding space. Lighting on the first floor of the dwelling is modeled according to a schedule that assumes no lights on from midnight to $8 \mathrm{a} \cdot \mathrm{m}$. Ten percent of the first floor lights are on from $8 \mathrm{a} \cdot \mathrm{m}$. to $5 \mathrm{p} . \mathrm{m}$. when various activities in various portions of the 
house require little lighting for short periods of time. From 5 p.m. to 9 p.m. lighting increases to $35 \%$ as darkness, cooking, and reading require more light. From 9 p.m. to midnight lighting decreases to $5 \%$ of total. Weekday basement lighting is assumed to be about $15 \%$ between the hours of $8 \mathrm{a} . \mathrm{m}$. and $8 \mathrm{p} . \mathrm{m}$. and zero at other times. On weekends, basement 1 ighting is modeled according to the schedule of $15 \%$ of the lights on from 7 p.m. to $10 \mathrm{pm}$. and no lights nn at other timec. Appliances such as refrigerators, stoves, washers and dryers, and dishwashers, as well as other minor household equipment can be important in determining residential energy consumption. First floor appliances which include television, refrigerator, dishwasher, and electric range are assumed to be operating $10 \%$ of the time between the hours of $8 \mathrm{a} . \mathrm{m}$. and $8 \mathrm{p} . \mathrm{m}$. for reasons of simplicity. Rather than attempt to determine which appliances are on during what periods, it was felt that a flat. usage curve which reflected the actual appliance energy usage but which did not reflect appliance use patterns was just as accurate. The same procedure is utilized to identify basement appliance usage in the modeling procedure. Basement appliances which include the clothes washer and dryer, are modeled on a schedule of operating between the hours of $8 \mathrm{a} . \mathrm{m}$. to $3 \mathrm{p} . \mathrm{m}$. on the days of Monday through Thursday at a capacity rating of $30 \%$.

The following set of diagrams in Figure 19 graphically represent the household schedules outlined above. 
OCCUPANCY

MONDAY THRU FRIDAY

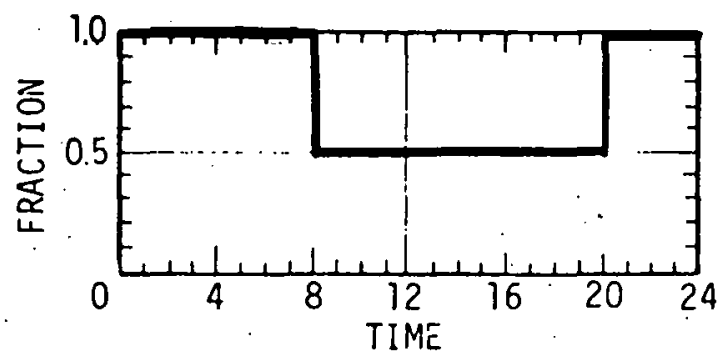

1st FLOOR LIGHTING

SUNDAY THRU SATURDAY

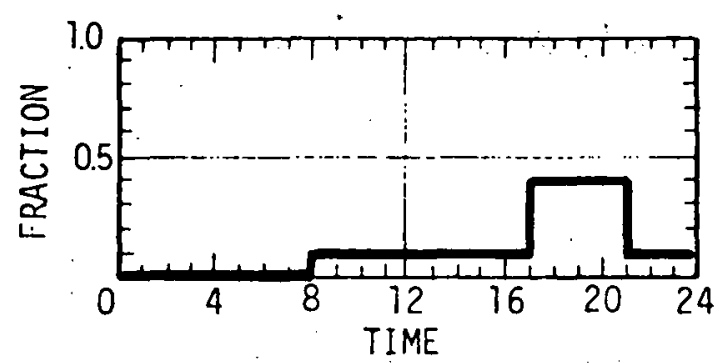

BASEMENT LIGHTING

MONDAY THRU FRIDAY

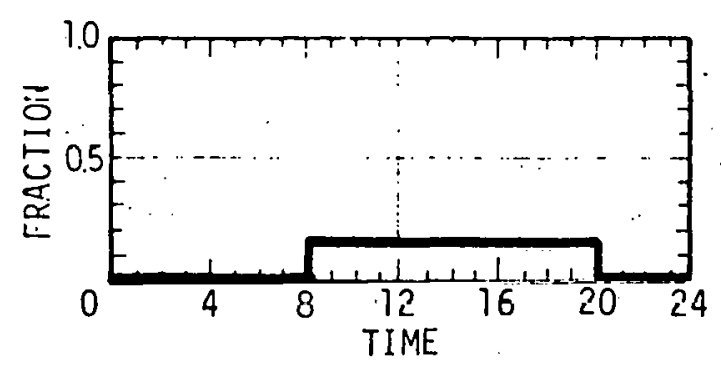

BASEMENT APPLIANCE

MONDAY THRU THURSDAY

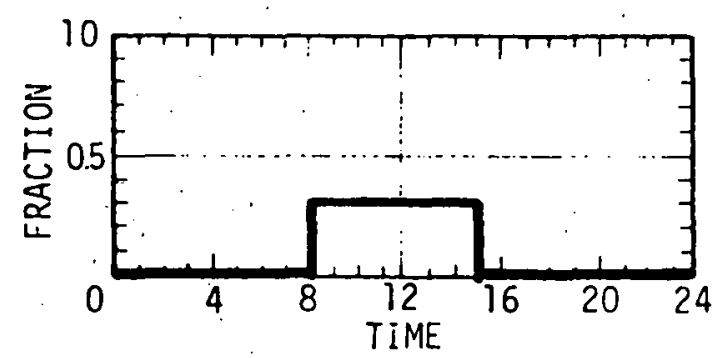

OCCUPANCY

WEEKENDS

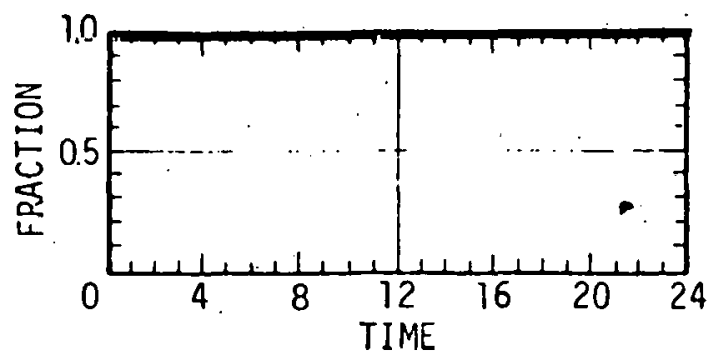

ist FLOOR APPLIAINCES

SUNDAY THRU SATURDAY

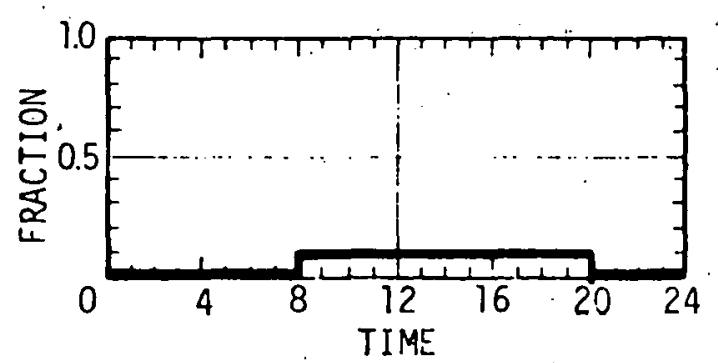

BASEMENT LIGHTINC IVEEKENDS
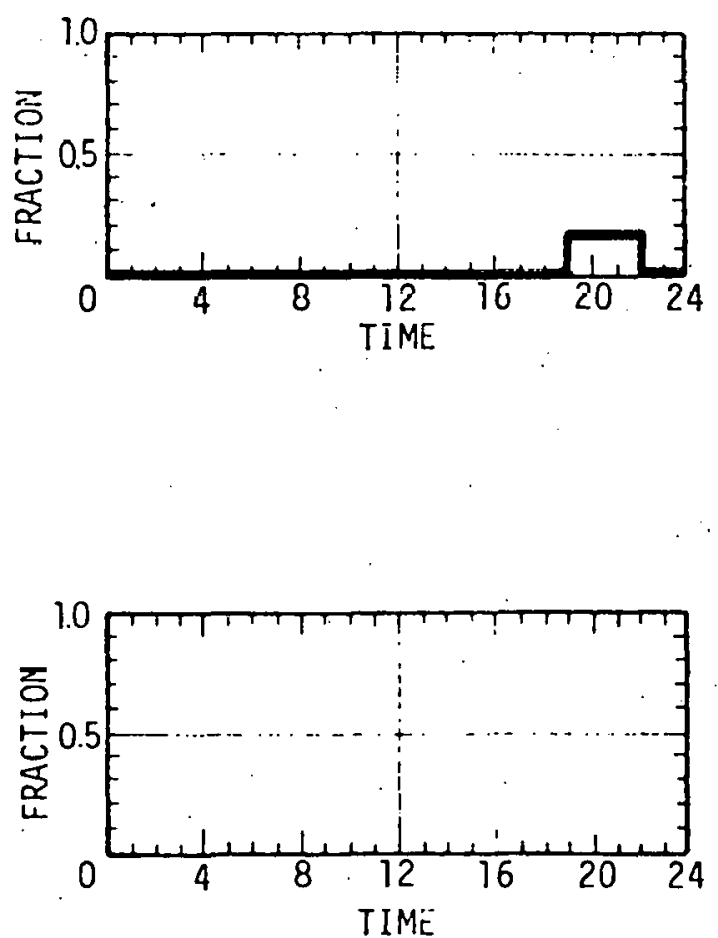

Fig. 19. Household schedules 


\section{EFFECT OF INSULATION LEVELS ON HEATING AND COOLING LOADS}

Insulation remains one of the best, easiest, and most cost effective methods of reducing energy consumption in buildings. Good design practices that incorporate energy conservation techniques, such as south facing window area, are also important in achieving energy efficiency. However, as stated earlier, these modifications are available only at the design stage. Insulation on the other hand, may be added after completion of the structure, although it is more advantageous to determine beforehand the correct amount and type of insulating material and include it as part of the construction of the building.

The purpose of this study is not to decide which type of insulation is best. So many factors are important in the decision-making process that to attempt to sort out the insulation picture in this report would not be advisable. Such properties as thermal conductance, moisture transmittance, fire resistance, ease of installation, range of use, material costs, durability, availability, and many others must be evaluated before a proper decision can be made as to insulating materials. As always, a weighing of the advantages against the disadvantages is necessary and what is right for one application may not be correct for another. However, it is one of the purposes of this report to study the effect of insulation in general on the heating and cooling demands of a particular residence.

The house as actually constructed contains six inches $(R-20)$ of fiberglass fill insulation in the ceiling and approximately two and one quarter inches $(R-7)$ of fiberglass batt insulation in the wall air space. 
The structure is modeled using DOE-1 according to these parameters. As calculated by the computer program, the annual heating load for the building amounts to -156.881 million BTU (MBTU). The negative sign represents a heat loss which must be replaced. The annual cooling load is computed to be $18.695 \mathrm{MBTU}$. The house is then modeled under conditions representing no insulation in either the ceiling or walls. Calculated values for the annual heating and cooling loads are -243.294 MBTU and 28.594 MBTU respectively. Based on the house with no insulation at all, insulating to the . current six inches in the ceiling and two and one quarter inches in the walls saves $35.5 \%$ on the heating load and $34.6 \%$ on the cooling load (see Table 3).

It is interesting to examine the peak loads as calculated by the LOADS program of DOE-1 (see Table 4). The annual heating peak for no insulation occurs on January 17 at $8 \mathrm{a} . \mathrm{m}$. and is determined to be $-176.380 \mathrm{KBTU} / \mathrm{HR}$ for the building. The heating peak under. the current levels of insulation is $-116.330 \mathrm{KBTU} / \mathrm{HR}$ which is a $34 \%$ decrease. It can be seen that together the walls and ceilings contribute over $50 \%$ of the peak heating loads without insulation. With the addition of the insulation, the heating load from these locations is substantially lowered. It can also be noted that aithough the wall load is reduced in terms of absolute value, its percentage contribution to the total peak load remains high. Infiltration is the major factor contributing to the heating peak:

The cooling peak occur on August 29 at 4 p.m. Once again with no insulation, the walls and ceiling represent the greatest area of energy loss. The ceiling in particular is a tremendous energy leak as it represents $50 \%$ of the total cooling load alone. With the addition of insulation, the total numerical contribution of the walls and ceiling to the 
cooling load decreases substantially. Once again, however, the percentage of the total cooling load contributed by the walls remains fairly high. As with the heating load, infiltration takes over as the major source of cooling loss, with solar radiation gain through the windows representing almost an additional quarter.

The computer program is then run to examine the effect of wall and ceiling insulation added separately. The fiberglass batt insulation is removed from the walls and various levels of celling insulation are tested. With the addition of three inches of insulating material $(\mathrm{R}-10)$. into the ceiling, the annual building heating load drops by $21.4 \%$ from -243.294 MBTU to -191.288 MBTU (See Table 3). Doubling the insulation to six inches $(R-20)$ results in a $25 \%$ reduction in annual heating load to -182.269 MB'T. But this is less than a $4 \%$ saving from the three inch value. The addition of nine inches (R-30) and 12 inches $(R-40)$ results in the yearly heating loads of -178.717 MBTU and -176.787 MBTU respectively. These values represent decreases of $26.5 \%$ and $2 \% .3 \%$ from the heating demand as calculated with no insulation. The cooling load results are similar as shown in Table 3 . A large decrease in cooling load from 28.594 MBTU with no insulation to 20.002 MBIU will Llıte incilies $(\mathrm{R}-10)$ is indicated as a $29.8 \%$ drop in energy used. Further additions of ceiling insulation show smaller incremental drops in cooling loads.

The situation is then reversed as the house is modeled with no ceiling insulation and under various levels of wall insulation. One can see that here the absolute values of the heating and cooling loads are much larger than under the previous test with the addition of ceiling insulation. With the addition of 2.25 inches of fiberglass batt in the walls $(R-7)$, the heating load drops from -243.294 MBTU to -217.716 
MBTU, a decrease of $10.5 \%$. However, further insulation added to the walls results in only minor energy conservation. As shown on the table, a staggering 9.7 inches $(R-30)$ added to the walls drops the heating load only to -209.599 MBTU or a decrease of $13.8 \%$. Of course wall space available for insulating material is normally limited to a comparatively small thickness, usually less than six inches. As shown by these calculations, this limitation is not detrimental since the addition of insulation above 3.5 inches does not lower the heating load significantly.

An interesting phenomenon is indicated with respect to the cooling load as wall insulation is added. The annual cooling load remains nearly constant, decreasing only $1.7 \%$ even as 9.7 inches $(R-30)$ of insulation are put in the walls. This would seem to indicate that walls, with their large thermal mass, are themselves effective insulators in terms of retarding loss of cooling energy supplied to the house. The thermal mass of the walls serves to inhibit the influx of heat from the outside. In other words, the majority of the cooling load is generated by cooling loss through the ceiling which does not contain the thermal mass supplied by brick walls. This effect is also reflected in the figures representing. heating lnad although the results are not so noticeable.

The fact that the annual heating load with wall insulation and no ceiling insulation is much higher than the annual heating load with no wall insulation and with ceiling insulation would indicate that the majority of heat loss is through the ceiling. To put it another way, as fiberglass batt is added to the walls there is still a large heat load after an initial $10.5 \%$ drop, indicating a large heat loss through the ceiling. But as fiberglass fill is added to the ceiling, this large thermal loss is plugged and the annual heating load is reduced 
significantly even with no insulation in the walls. This is not to say that wall insulation is not important and should be eliminated. It means only that the major energy leak in the study house is through the. ceiling and that morc insulating material is necessary in this location to reduce energy demand. The construction of the walls themselves makes them effective insulators and less insulation material is needed there to guard against energy loss.

The curves generated illustrate the effect of added insulation (in creased R-value) on building heating and cooling loads. It is important to note the shape of the curves. In three of the four graphs the building. heating or cooling load drops dramatically with the first installation of insulation and then tends to level out. This would show that in the case of insulation, the popular notion of "the more the better" does not apply. The resultant savings of only a few MBTU with the addition of the next level of insulation is not justified economically. In the case of this particular residence, the current levels of six inches in the ceiling and 2.25 inches in the walls seems to be correct for the particular location and climate. 
TABLE 3. Effect of insulation on heating and cooling loads

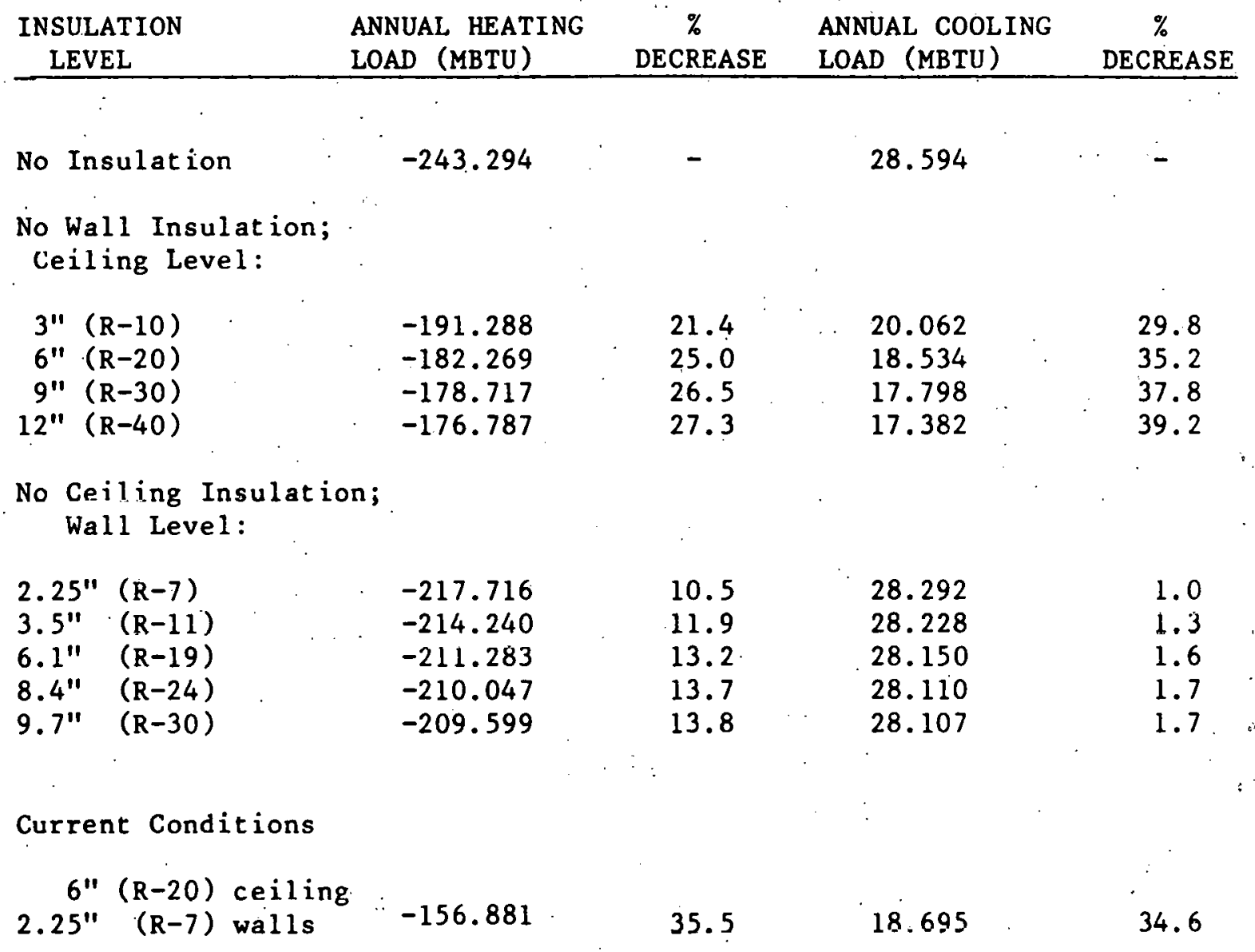


TABLE 4. Comparison of peak loads with no insulation and with 6" fiberglass fill in ceiling and

$2.25^{\prime \prime}$ fiberglass batt in walls

HEATING PEAK: JANUARY 178 A.M.

\begin{tabular}{|c|c|c|c|c|}
\hline $\begin{array}{l}\text { Building } \\
\text { Component }\end{array}$ & $\begin{array}{l}\text { No Insulation } \\
(\mathrm{KBTU} / \mathrm{HR}) *\end{array}$ & $\begin{array}{l}\% \text { of } \\
\text { Total }\end{array}$ & $\begin{array}{l}\text { Current Insulat ion } \\
\text { (KBTU/HR)* }\end{array}$ & $\begin{array}{r}\% \text { of } \\
\text { Total } \\
\end{array}$ \\
\hline Walls & -46.297 & 26.2 & -28.683 & 24.6 \\
\hline Ings & -50.323 & 28.5 & -7.887 & 6.7 \\
\hline Glass Conduction & -12.266 & 7.0 & -12.266 & $10 . \overline{5}$ \\
\hline Glass Solar & .646 & .3 & .646 & .5 \\
\hline Internal Surfaces & 0.000 & - & 0.000 & - \\
\hline Underground Surfaces & -28.299 & 16.0 & -28.299 & 24.3 \\
\hline Occupants to Space & .595 & .3 & .595 & .5 \\
\hline Lights to Space & .169 & 0 & .169 & .1 \\
\hline Equipment to Space & 5.904 & 3.3 & 5.904 & 5.1 \\
\hline Process to Space & 0.000 & - & 0.000 & - \\
\hline Infiltration & $\frac{-46.509}{-176.380}$ & 26.3 & $\frac{-46.509}{-116.330}$ & 40.0 \\
\hline
\end{tabular}

*Negative sign represents heat loss; positive sign represents heat gain.

COOLING PEAK: AUGUST 29 4 P.M.

\begin{tabular}{lcrrr}
$\begin{array}{l}\text { Building } \\
\text { Component. }\end{array}$ & $\begin{array}{c}\text { No Insulation } \\
\text { (KBTU/HR)** }\end{array}$ & $\begin{array}{c}\% \text { of } \\
\text { Total }\end{array}$ & $\begin{array}{r}\text { Current Insulation } \\
\text { (KBTU/HR)** }\end{array}$ & $\begin{array}{r}\% \text { of } \\
\text { Total }\end{array}$ \\
\hline Walls & 15.854 & 20.6 & 8.972 & 18.7 \\
Ceilings & 40.763 & 50.0 & 3.407 & 7.1 \\
Glass Conduction & 2.907 & 3.5 & 3.445 & 7.2 \\
Glass Solar & 11.000 & 13.5 & 11.380 & 23.7 \\
Internal Surfaces & 0.000 & - & 0.000 & - \\
Underground Surfaces & -.976 & 1.2 & -.976 & 2.0 \\
Occupants to Space & .339 & .4 & .339 & .7 \\
Lights to Space & 1.024 & 1.2 & 1.021 & 2.1 \\
Equipment to Space & 7.116 & 8.7 & 7.075 & 14.7 \\
Process to Space & 0.000 & - & 0.000 & - \\
Infiltration & 2.537 & 3.1 & 13.260 & 27.6 \\
& 81.563 & & 47.260 &
\end{tabular}

**Negative sign represents cooling gain; positive sign represents cooling load. 


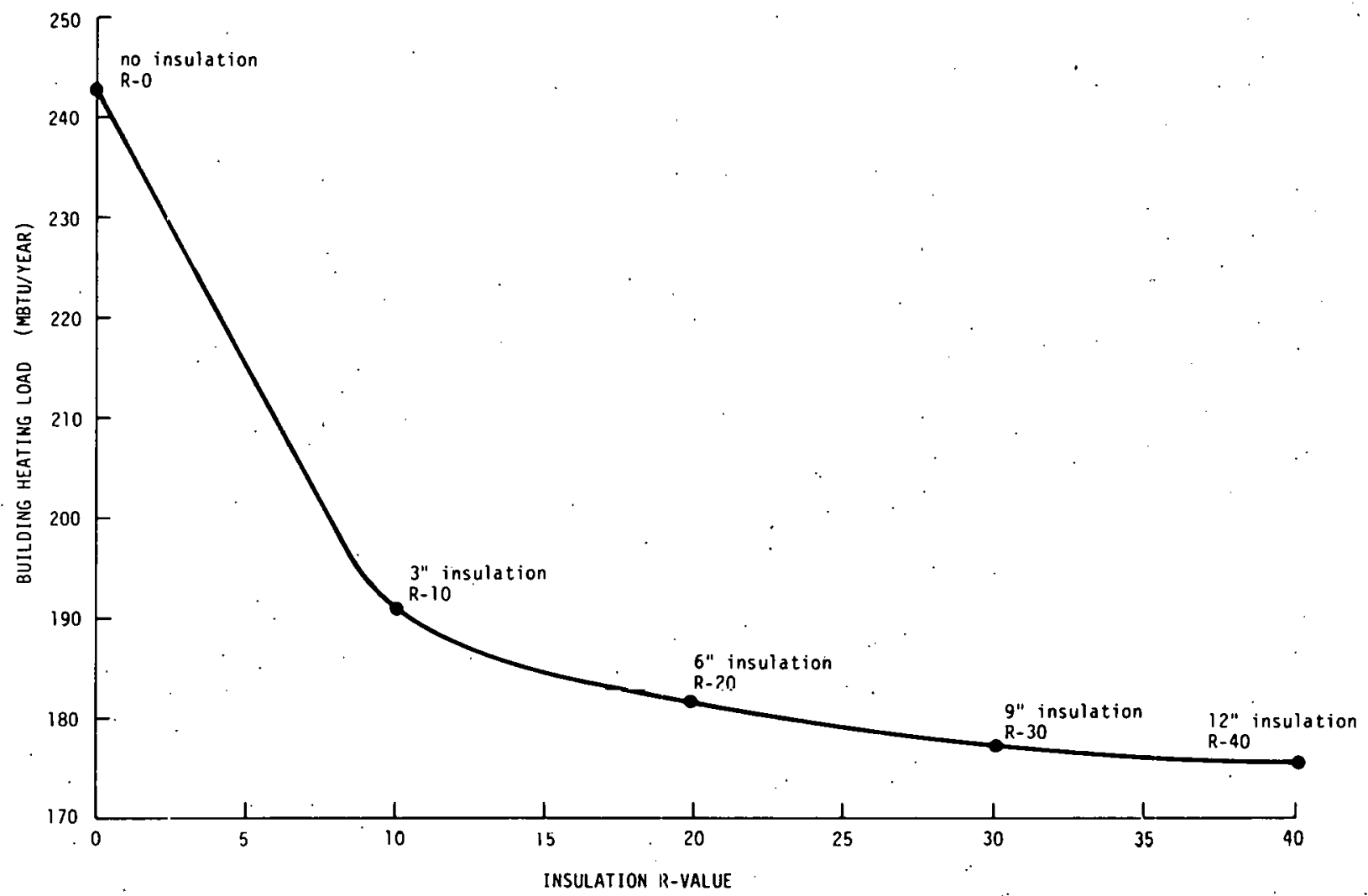

Fig. 20. Effect of ceiling insulation on heating load as calculated by DOE-1. This graph illustrates the effect of various levels of ceiling insulation on the building heating load. Wall insulation has been eliminated to isolate only the effect of the ceiling insulation. As insulation is added ( $R$-value is increased) from none to three inches the bullding heating load decreases substantially from about, $243 \mathrm{MBTU} /$ year to near $190 \mathrm{MBTU} /$ year. Doubling the insulation to six inches $(\mathrm{R}-20)$ further decreases the annual heating demand to about $182 \mathrm{MBTU} /$ year. Note that as more. insulating material is added to the ceiling, building heating loads do not decrease as rapidly. In fact there is almost a flattening out of the curve so that an increase from nine inches to twelve inches results in almost no reduction in heating load. This refutes the popular stance that "the more the better" in regard to insulation. 


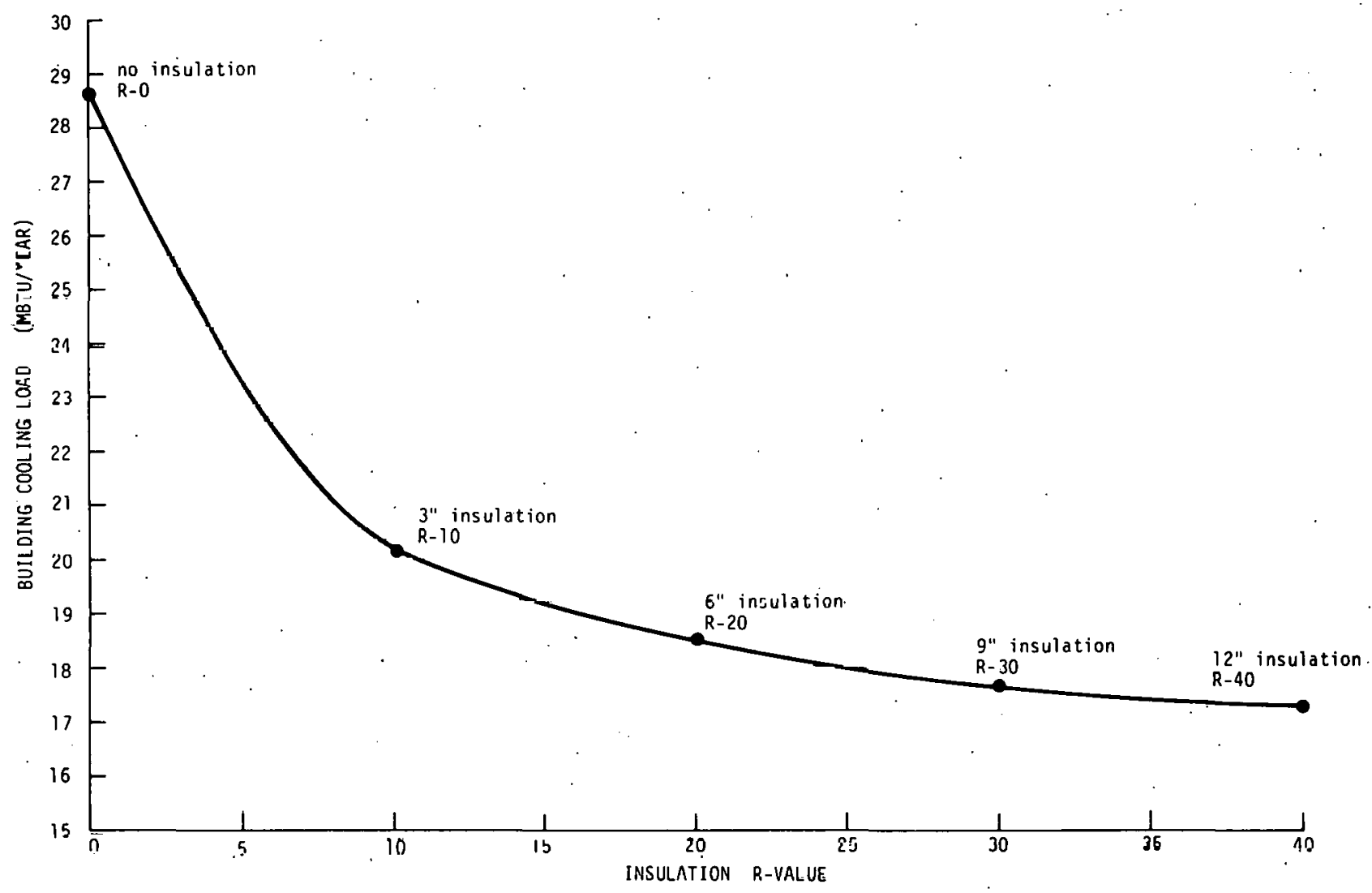

Fig. 21. Effect of ceiling insulation on cooling load as calculated by DOE-1. This graph illustrates the effect of various levels of ceiling insulation on the bullding cooling load. Wall insulation has heen eliminated to isolate only the effect of the ceiling insulation. This graph also Illustrates a point of diminiehing returns since. the addition of insulation above six inches (R-20) has 1ittle effect on reducing the annual conling load. 


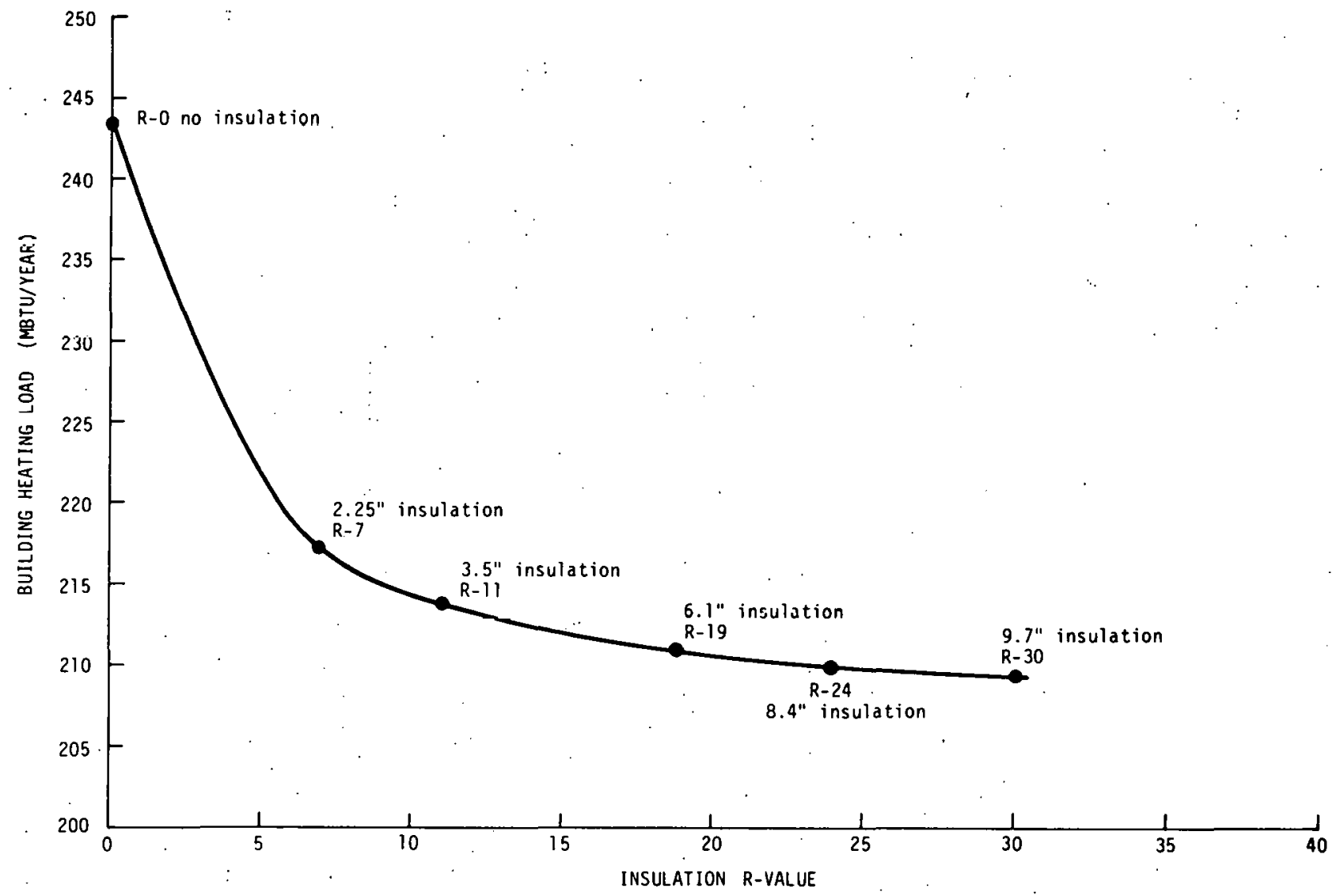

Fig. 22. Effect of wall insulation on heating load as calculated by DOE-1. This graph illustrates the effect of various levels of ceiling insulation on the building heating load. Ceiling insulation has heen eliminated to isolate only the effect of the wall insulation. As with the previous graphs, a curved line shows that as the Insulation level in the wall is increased, the building heating load decreases but at a decreasing rate. In fact, increasing from $R-24$ ( 8.4 inches) to $R-30$ (9.7 inches) has practically no effect on building heating load. 


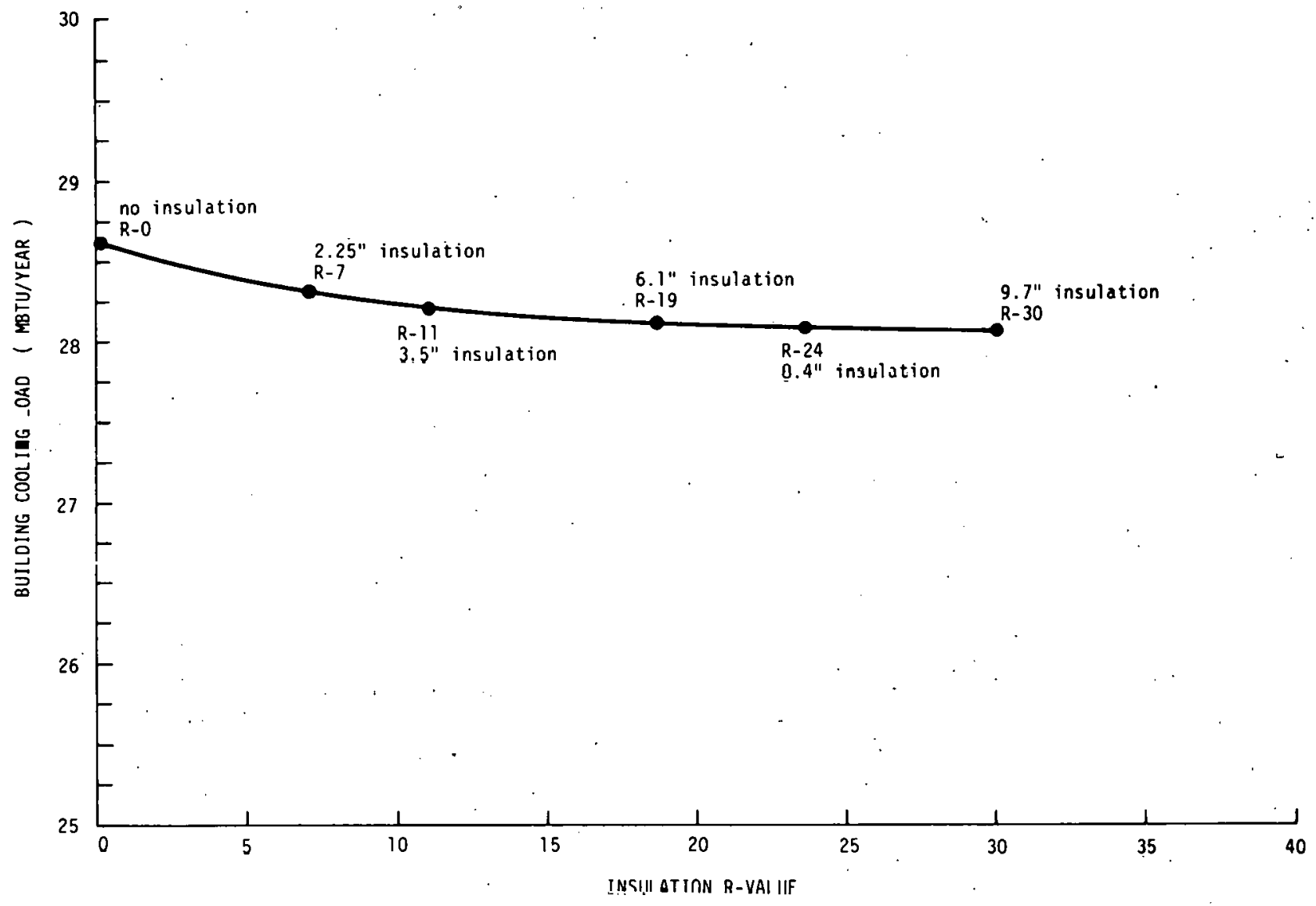

Fig. 23. Effect of wall insulation on cooling load as calculated by DOE-1. This graph illustrates the effect of varlous levels of wall insulation on the bullding cooling load. As with the preceding graph, ceil.ing insulation is eliminated to isolate only the effect of the wall insulation. Conversely to the previouo diagrams, this line is almost straight as more insulating material is added. This indicates that the wall insulation has little effect un reducing the cooling load for the building. This can be explained by the makeup of the walls themselves. The brick and mortar of the walls have the property of a substantial thermal mass. Heat from the outside takes a long time to penetrate this material. Therefore, the walls themselves act as an insulator and the addition of artificial insulation materfal has little effect on reducing cooling load. The values of the cooling load are high due to the removal of the ceiling insulation. The construction of the ceiling does not entail a high thermal mass and therefore, represents a potential high leakage of cooling energy if not properly insulated. 


\section{EFFECT OF SINGLE AND DOUBLE GLAZED WINDOWS \\ ON HEATING AND COOLING LOADS}

Storm windows installed on a residence are another method ef fectively reducing energy consumption. The test house as currently constructed uses double glazing on all windows either in the form of separate storm windows or as two panes of glass encased in the window frame itself. In order to

test the effect double glazing of windows has on heating and cooling loads for the building, the DOE-1 computer program was run once with single glazing in the windows and once with double glazed windows. All other components of the house were kept constant to isolate only the effect the number of panes of glass has on energy demand.

Table 5 summarizes the results of this test. With the addition of a second pane of glass, the annual building heating load is reduced by almost 10 MBTU from a value of -166.790 MBTU with single glazing to -156.881 MBTU with double glazing or by about $6 \%$. The annual cooling load is lowered by more than 1 MBTU from 19.763 MBTU with single pane windows to 18.695 MBTU with double panes of glass which represents a $5.4 \%$ decrease in cooling energy needed.

A comparison of peak loads for the test is shown on Table 6 . The heating peak again occurs on January 17 at 8 A.M. With the addition of a second pane of glass on all the windows, the building peak is reduced from $-124.052 \mathrm{KBTU} / \mathrm{HR}$ to $-116.330 \mathrm{KBTU} / \mathrm{HR}$ or by about $6.2 \%$. The only change is due to Glass Conduction and Glass Solar, with the former representing the major difference between the runs. With only single glazed windows, Glass Conduction contributes a heat loss of $-20.070 \mathrm{KBTU} / \mathrm{HR}$ or about $16.2 \%$ of the total heating peak. A second layer of glazing reduces this heat loss to $-12.266 \mathrm{KBTU} / \mathrm{HR}$ and a value of $10.5 \%$ of the 
total peak. Heat gain through the windows as shown under the heading of Glass Solar is reduced slightly from $.728 \mathrm{KBTU} / \mathrm{HR}$ to $.646 \mathrm{KBTU} / \mathrm{HR}$ with the installation of a double glazing. Of course, it is desirable to have a solar heat gain through the windows to help reduce heat input by artificial means. With the addition of double glass, the reduction of solar input through the windows is small compared with the reduction of heat loss. Therefore it makes sense to trade a small reduction in solar input for a large reduction in heat $108 s$ by using two panes of glass.

The situation reverses itself upon examination of the cooling peak occurring on August 29 at 4 P.M. In this case, heat gain through windows represents a major fraction of the cooling load. With the addicion of double glazing, this Glass Solar heat load is reduced from $13.189 \mathrm{KBTU} / \mathrm{HR}$ and $25.3 \%$ of the peak to $11.380 \mathrm{KBTU} / \mathrm{HR}$ and $23.7 \%$ of the peak. In addition, Glass Conduction is dropped from 5.686 KBTU/HR and $10.9 \%$ of the total peak to $3.445 \mathrm{KBTU} / \mathrm{HR}$ and $7.1 \%$ of the total peak. These two parameters have the combined effect of reducing total peak cooling load from $51.972 \mathrm{KBTU} / \mathrm{HK}$ to $47.922 \mathrm{KBTU} / \mathrm{HR}$ or by about $7.8 \%$.

Unfortunately, there is no method to determine what effect triple glazing has on building energy demand as the maximum number of window panes currently allowed by the computer program is two. It can be theorized that, as with insulation, a point of diminishing returns is reached. Addition of even triple glazilig way not reducc energy demand enough to justify their expense. 
TABLE 5. Effect of double glazed windows on heating and cooling loads

\begin{tabular}{|c|c|c|c|c|c|c|}
\hline $\begin{array}{l}\text { WINDOW } \\
\text { CONDITIONS }\end{array}$ & $\begin{array}{c}\text { ANNUAL } \\
\text { HEATING LOAD }\end{array}$ & (MBTU) & $\begin{array}{c}\% \\
\text { DECREASE }\end{array}$ & $\begin{array}{c}\text { ANNUAL } \\
\text { COOLING LOAD }\end{array}$ & (MBTU) & $\begin{array}{c}\% \\
\text { DECREASE }\end{array}$ \\
\hline $\begin{array}{l}\text { Single } \\
\text { Glazed }\end{array}$ & -166.790 & . & - & 19.763 & . & - \\
\hline $\begin{array}{l}\text { Double } \\
\text { Glazed }\end{array}$ & -156.881 & & 5.9 & 18.695 & & 5.4 \\
\hline
\end{tabular}

TABLE 6. Comparison of peak loads with single glazed windows and double glazed windows

HEATING PEAK: JANUARY 178 A.M.

\begin{tabular}{lrrrr}
$\begin{array}{l}\text { Building } \\
\text { Component }\end{array}$ & $\begin{array}{c}\text { Single Glazed } \\
\text { (KBTU/HR)* }\end{array}$ & $\begin{array}{c}\% \text { of } \\
\text { Total }\end{array}$ & $\begin{array}{r}\text { Doubled Glazed } \\
\text { (KBTU/HR)* }\end{array}$ & $\begin{array}{r}\text { \% of } \\
\text { Total }\end{array}$ \\
\hline Walls & -28.683 & 23.1 & -28.683 & 24.6 \\
Ceilings & -7.887 & 6.3 & -7.887 & 6.7 \\
Glass Conduction & -20.070 & 16.2 & -12.266 & 10.5 \\
Glass Solar & .728 & .6 & .646 & .5 \\
Internal Surfaces & 0.000 & - & 0.000 & - \\
Underground Surfaces & -28.299 & 22.8 & -28.299 & 24.3 \\
Occupants to Space & .595 & .4 & .595 & .5 \\
Lights to Space & .169 & .1 & 5.904 & .1 \\
Equipment to Space & 5.904 & 4.7 & 0.000 & 5.0 \\
Process to Space & 0.000 & - & -46.509 & -169 \\
Infiltration & -46.509 & 37.5 & -116.330 & 39.9
\end{tabular}

*Negative sign represents heat loss; positive sign represents heat gain.

COOLING PEAK: AUGUST 294 P.M.

\begin{tabular}{|c|c|c|c|c|}
\hline $\begin{array}{l}\text { Building } \\
\text { Component }\end{array}$ & $\begin{array}{l}\text { Single Glazed } \\
(\mathrm{KBTU} / \mathrm{HR}) \star \star\end{array}$ & $\begin{array}{l}\% \text { of } \\
\text { Total } \\
\end{array}$ & $\begin{array}{c}\text { Double Glazed } \\
\text { (KBTU/HR)* }\end{array}$ & $\begin{array}{l}\% \text { of } \\
\text { Total }\end{array}$ \\
\hline Walls & 8.972 & 17.2 & 8.972 & 18.7 \\
\hline Ceilings & 3.407 & 6.5 & 3.407 & 7.1 \\
\hline Glass Conduction & 5.686 & 10.9 & 3.445 & 7.1 \\
\hline Glass Solar & 13.189 & 25.3 & 11.380 & 23.7 \\
\hline Tnternal Surfaces & 0.000 & - & 0.000 & - \\
\hline Underground Surfaces & -.976 & 1.8 & -.976 & 2.0 \\
\hline Occupants to Space & .339 & .6 & .339 & .7 \\
\hline Lights to Space & 1.021 & 1.9 & 1.021 & 2.1 \\
\hline Equipment to Space & 7.075 & 13.6 & 7.075 & 14.7 \\
\hline Process to Space & 0.000 & - & 0.000 & - \\
\hline Infiltration & $\frac{13.260}{51.972}$ & 25.5 & $\frac{13.260}{47.922}$ & 27.6 \\
\hline
\end{tabular}

**Negative-sign represents cooling gain; positive sign represents cooling load. 


\section{EFFECT OF THERMOSTAT SETTINGS ON HEATING AND COOLING LOADS}

Thermostat settings are a third factor that influence energy usage in the residential sector. It is perhaps the simplest method of reducing consumption in that it involves no expense in terms of materials or labor and yet a simple temperature adjustment may save substantial amounts of energy. The DOE- 1 computer program is constructed so that the LOADS calculations are based on a constant yearly indoor temperature. The SYSTEMS portion of the program allows manipulation of thermostat settings to achieve a more realistic picture of energy consumption. The LOADS program was carried out using a temperature of $70^{\circ} \mathrm{F}$ which was determined to be the yearly average indoor temperature for the house. In utilizing the SYSTEMS program, heating schedules were developed to allow a $68^{\circ} \mathrm{F}$ thermostat setting in daytime and a setback of $63^{\circ} \mathrm{F}$ at night during the winter: During the cooling season a continuous setting of $78^{\circ} \mathrm{F}$ was modeled. Therefore, a single computer run allowed the isolation of the effect of thermostat settings on heating and cooling demand as the LOADS results reflect no temperature adjustments and the SYYSTEMS results show the effect of thermostat setbacks.

The results of this test are shown on Table 7 . With the implementation of thermostat adjustments, the annual building heating load is reduced from $-211,276 \mathrm{MBTU}$ to $-156.881 \mathrm{MBTU}$. This represents a $25.7 \%$ decrease in energy consumption just by setting the thermostat at $680 \mathrm{~F}$ in the daytime period and down to $63^{\circ} \mathrm{F}$ at night during winter. The cooling load savings are even more substantial. With a temperature setting of $78^{\circ} \mathrm{F}$ during the summer instead of the yearly average of $70^{\circ} \mathrm{F}$, annual cooling load drops from 62.608 MBTU to $18.695 \mathrm{MBTU}$. This is an incredible $70.1 \%$ decrease in energy consumed for cooling purposes. One can see from these 
results that although thermostat settings are perhaps the simplest method of energy conservation, their implementation seems to assure the most dramatic effect in terms of saving energy. The results may be as great or greater than the results indicated by more tangible forms of energy conservation such as insulation and double glazing windows.

TABLE 7. Effect of thermostat settings on heating and cooling loads

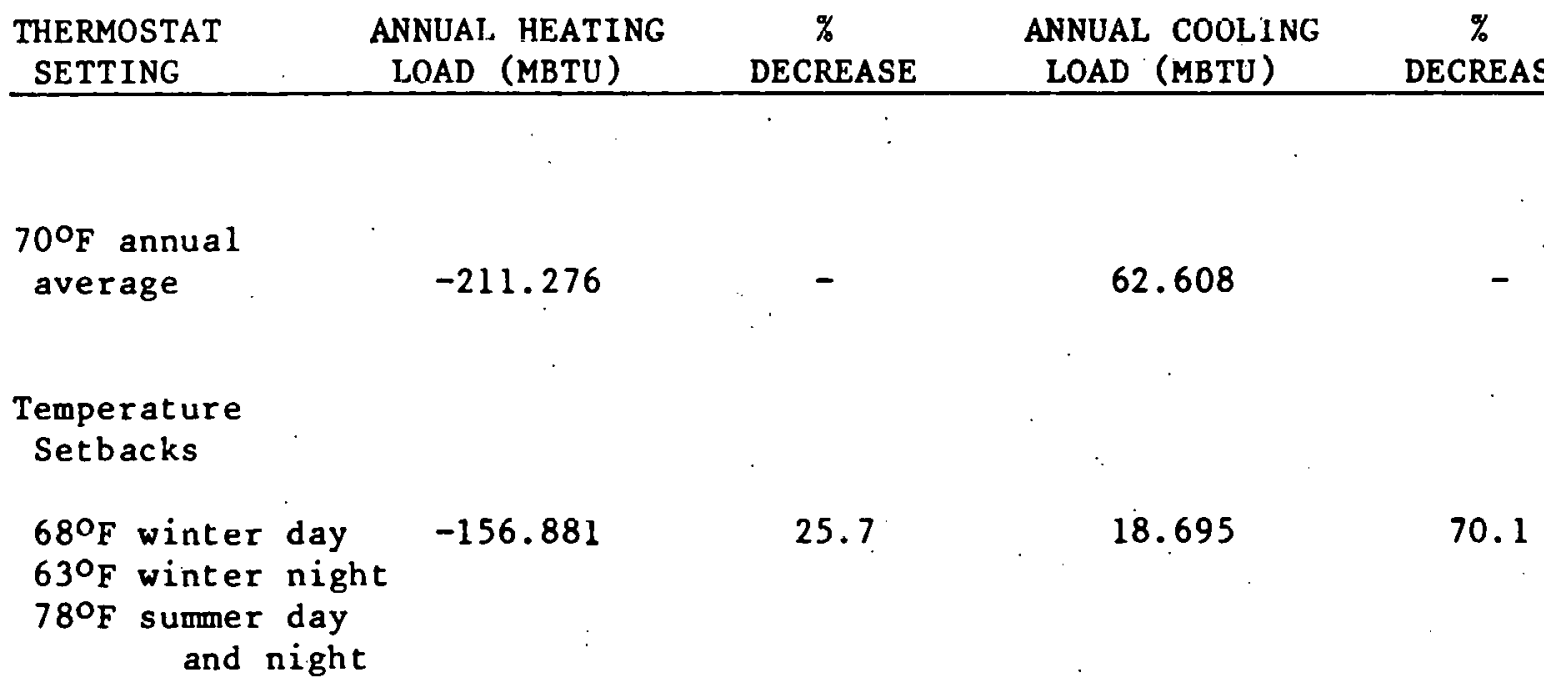




\section{ENERGY DISTRIBUTION SYSTEMS}

As indicated previously, the SYSTEMS program of DOE-1 simulates the operation of distribution systems that deliver heating and/or cooling energy directly to the spaces being modeled. The energy load values calculated for. a particular distribution system are not necessarily identical to the hourly space loads as determined earlier by the LOADS program. This is because such variables as ventilation air requirements, HVAC equipment operating characteristics, and temperature settings, which are not utilized in the calculation of hourly space requirements in the LOADS program, are taken into account when simulating a particular system. under a SYSTEMS simulation.

Two different distribution systems are initially.tested under the SYSTEMS program. The first is a Unit Heater, abbreviated UHT. This model consists of: 1) a heating coil (some source of heat, whether it be a gas furnace, steam boiler, or electric resistance. 'It does lut watter to the SYSTEMS program what that source is, as primary energy converters are simu=, lated separately under the PLANT program), 2) a supply fan, and 3) a thermostat control. THE UHT system is not capable of introducing outside air but can only recirculate conditioned air. Space cemperalure control ic accomplished by throttling or on-off control of the heating fluid. No cooling capacity is available under this system. Figure 24 shows a simple diagram of the Unit heater.

The second system chosen for modeling this residence is a Single Zone Fan System with optional Sub-Zone Reheat (SZRH). This system represents a slightly truer picture of the structure's present heating and cooling delivery system in that it simulates a constant volume forced air heating and cooling system for a single zone from an air handing unit containing 


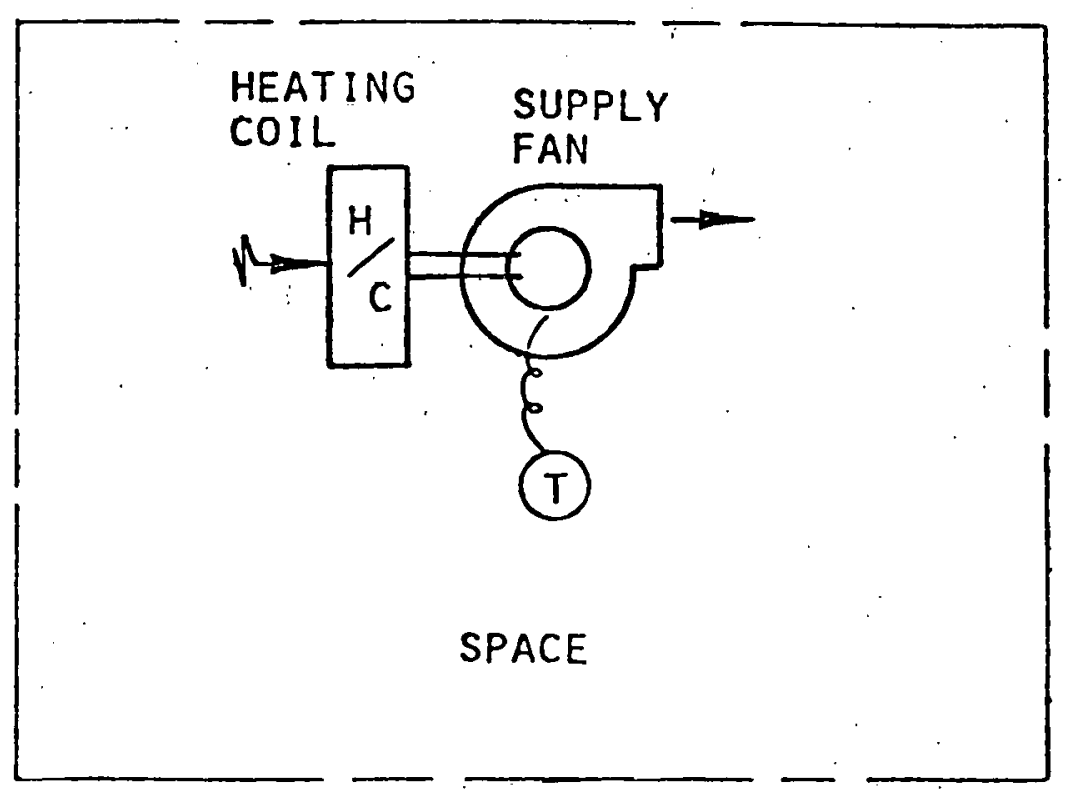

Fig. 24. Unit heater (UHT) 
a heating coil, a cooling coil, filters, and a supply fan. Zone temperature is controlled by a thermostat that senses space conditions within the zone. This system also has the option of providing outside air or it can be modeled to just recirculate conditioned air. Recirculation of conditioned air is chosen for this simulation as this is how the actual system in the house works. Figure 25 illustrates the make-up of the SZRH system. Note that components in the dashed boxes on the diagram represent optional equipment which is not modeled in the szRil gyotom for a single family dwelling. These licus are available for larger or commercial systems.

The comparison of the two systems is made in an effort to determine which system would be the optimum selection when utilizing the PLANT programs. The UHT is simpler but does not include the capability of cooling simulation. The SZRH is slightly more complicated in terms of input but represents a wure accurate pirture of the actual distribution system. Some modifications are necessary in the input data in order co simu late the two systems. Under the LOADS program, the first floor and the basement, are conditioned. That is, heating of cooling energy is supplied to them by the building's furnace and air conditioner. The unconditioned zone, the garage, does not receive conditioned air intcntionally but does exert an influence on building energy demands. The elimination of the attic zone was described in the "Methodology" section earlier. The UHT and SZRH systems are designed to provide heating and cooling capacity to a single zone. Thus it is necessary to combine the two conditioned zones (the basement and the first floor) into a single large zonc. This is done by eliminating the floor that separates the two. This does not represent as drastic a change as it would seem. Since the first floor and the 


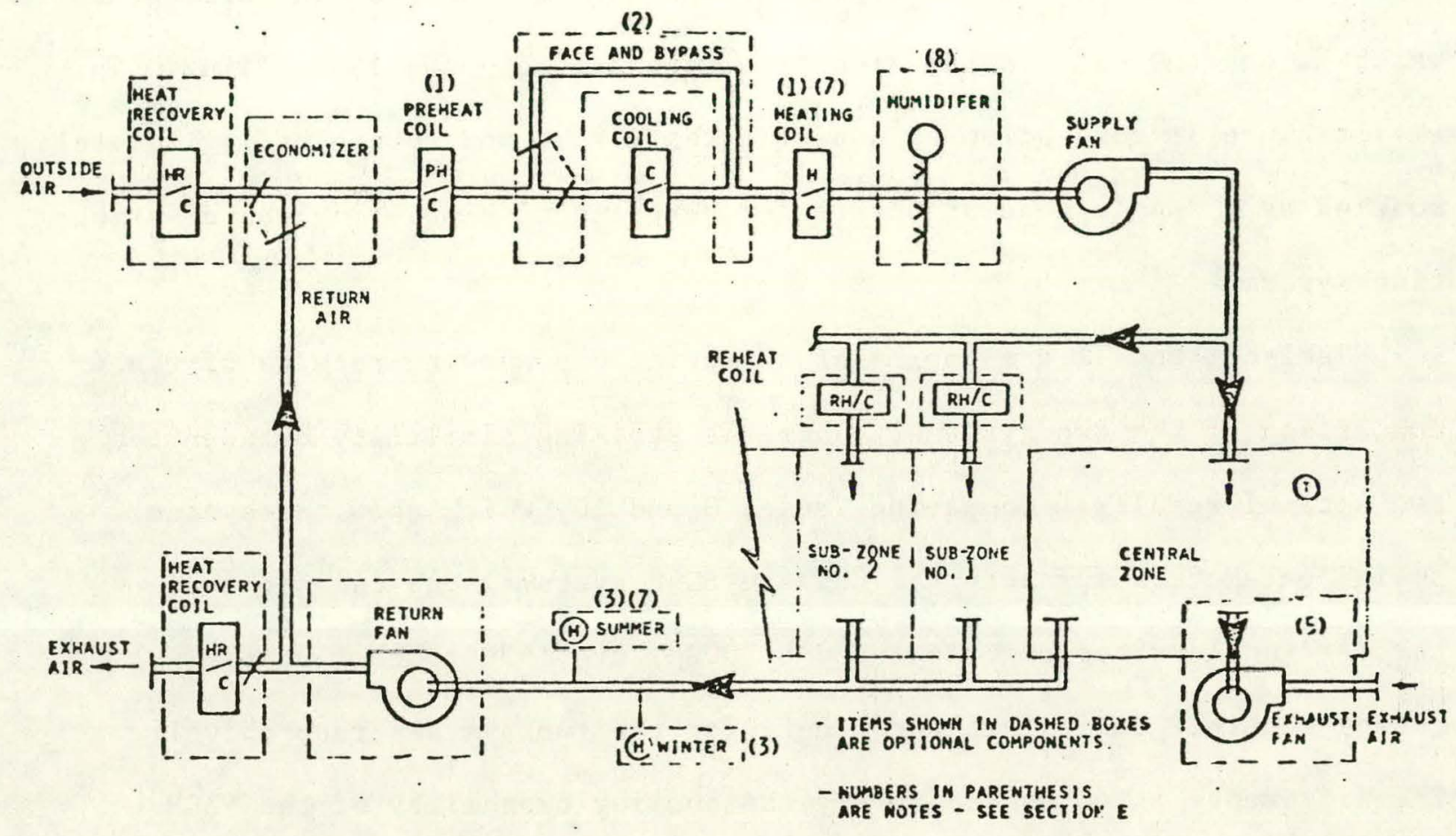

Fig. 25. Single zone fan system with optional sub-zone reheat (SZRH) 
basement are supplied with conditioned air by the same system, are adjacent to one another, and are controlled by the same thermostat, they do in fact approach the characteristics of a single zone. There are systems within DOE-1 to model multi-zone buildings. However, these act on the premise that each zone is individually controlled (has its own thermostat), which is not the case in the situation with a single family dwelling. The entire house is controlled by a single thermostat and so can be legitimately modeled as a single zone structure for purposes of simulating the distribution system.

Tables 8 and 11 are copies of the printouts showing results of the comparison of the two systems. There is striking similarity between the two sets of results. Comparing Tables 8 and 10, which show the system design parameters for both the UHT and SZRH systems, one can see that the design flowrates as calculated by DOE-1 are 1550 cubic feet per minute and 1622 cubic feet per minute for the two systems respectively. The difference is accounted for by the cooling capability of the SZRH system, while the UHT system, which does not possess this characteristic, dictates a slightly lower CFM rating. These values compare favorably with the present $1 / 2 \mathrm{~h} . \mathrm{p}$. blower actually in the furnace which is rated at around $1500 \mathrm{CFM}$. The design heating peaks are identical at -115.68 $\mathrm{KBTU} / \mathrm{HR}$ since the same structure is modeled for both systems. This, however, is undoubtedly high in comparison to the actual building heating peak due to the modifications made in the building construction for modeling purposes (elimination of the attic, etc.) as described earlier. Note also that no design cooling peak is calculated for the UHT system as building cooling is not available under this system. The building design cooling peak is determined to be $47.05 \mathrm{KBTU} / \mathrm{HR}$ for the SZRH system. The supply fan electrical demands for the two systems are 
nearly identical with the UHT supply fan drawing . $18 \mathrm{KW}$ and the SZRH supply fan drawing .19 KW. The difference is due to the slightly higher design flowrate calculated for the SZRH system. More electrical power is needed to supply this additional air flow.

Tables 9 and 11 show the system load summaries for the UHT and SZRH systems respectively. The monthly heating totals for the two systems are very similar. The average difference between the monthly heating loads for the two systems is .045 MBTU which averages out to be $.4 \%$ of the monthly heating load. The yearly total for the UHT system is -114.717 MBTU while the annual load under the SZRH system sums to -115.107 MBTU. This represents only a $.34 \%$ difference and points out the similarity of the two delivery systems for heat distribution. The peak load figures are equally similar. Of course, no cooling is possible with the UHT system so no comparison can be made in this category between the two systems. The difference in electrical demand is due to the slightly larger blower capacity required by the SZRH system. However, this difference amounts to on $1 y .3 \%$ in the annual electrical energy total and only . $2 \%$ of the peak electrical load.

It was felt that the SZRH system should be be used in performing the PLANT and ECONOMICS simulations for the dwelling since it is more like the system currently installed in the residence. The fact that the SYSTEMS program results are so similar illustrates that the modeling procedure was fairly accurate for the two systems.

Heat pumps are an alternative energy providing system available to homeowners. Because of their energy efficiency and increasing popularity as a means of supplying heating and cooling, it was decided to simulate a model of a heat pump system. DOE-1 includes the Unitary Heat Pump System, 
as shown in Figure 26, within the SYSTEMS program. The heat pump unit consists of a filter, an air circulating fan, and the refrigeration system. The refrigeration system in turn is composed of a reciprocating compressor, a room air-to-refrigerant heat exchanger, a water-torefrigerant heat exchanger, and controls to switch the evaporating and condensing modes from one heat exchanger to the other. Under the heating mode of operation, the room air-to-refrigerant heat exchanger is used for refrigerant condensing. In the cooling cycle, the water-to-refrigeraul heat exchanger provides refrigerant evaporation.

Temperature control in the zone conditioned by the heat pump is executed by on-off operation of the compressor fan. The thermostat type used for this system includes two different temperature set points. The system provides cooling when the space temperature increases to the upper set point of the thermostat. Heating is supplied when the space temperature falls to the lower set point. When the space temperature is between the two set points the system does not operate. The system allows only recirculation of conditioned air; no outside ventilation is currently available with the heat pump.

The program simulation of the heat pump system assumes that the heat pump requires $0.3 \mathrm{BTU}$ of equivalent electrical energy for each BTU of heat extracted from the space and 0.4 BTU of equivalent electrical energy for each BTU of heat added to the space.

Tables 12 and 13 are copies of the output of the heat pump system simulation. Table 12 which shows the system design parameters for the heat pump, indicates that the heating and cooling peaks are $-115.68 \mathrm{KBTU} / \mathrm{HR}$ and $47.05 \mathrm{KBTU} / \mathrm{HR}$ respectively. These are identical to the values determined for the UHT and SZRH systems since the same structure is being 


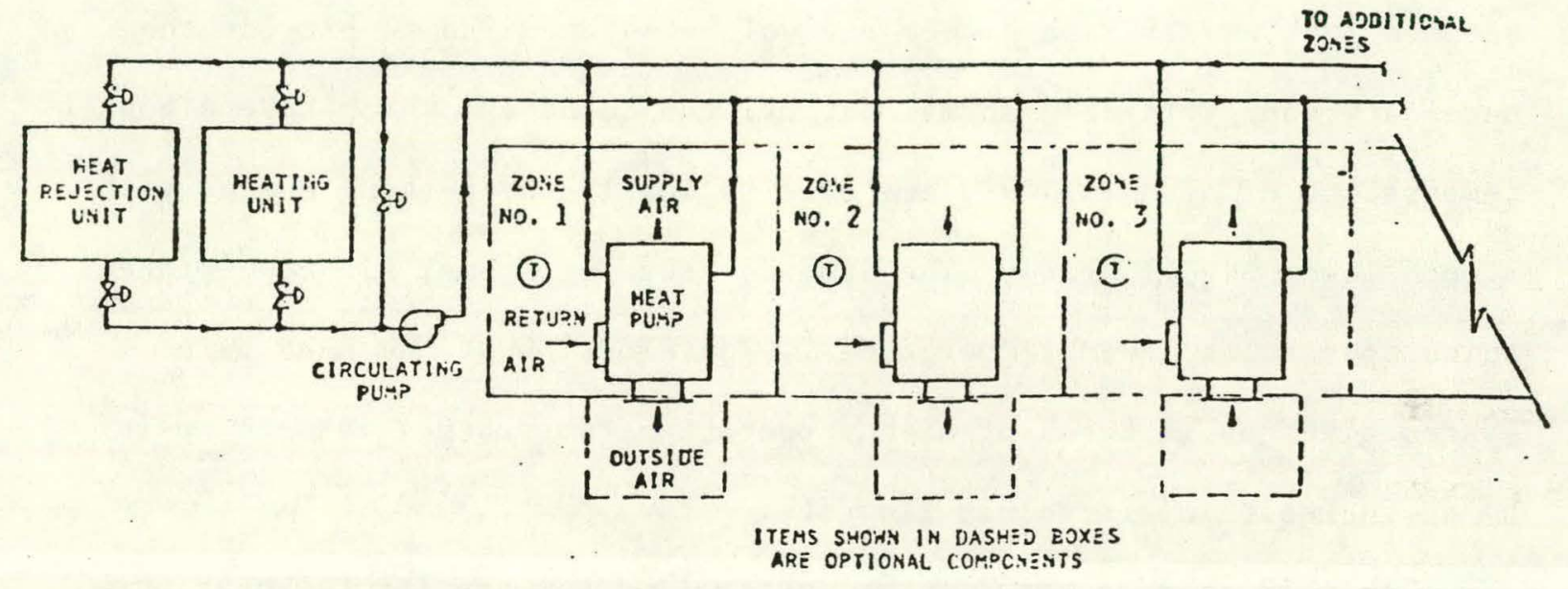

Fig. 26. Unitary heat pump system 
modeled in all three cases. The difference lies in the design air flowrates. For the heat pump system this is calculated to be 5668 cubic feet per minute. This increase over the other systems (1550 CFM for the UHT and 1622 CFM for the SZRH) is undoubtedly due to the heat pump's lower operating temperature. Since the circulating fluid which provides the heating and cooling energy commonly is maintained at temperatures of between $70^{\circ} \mathrm{F}$ and $90^{\circ} \mathrm{F}$, a higher air volume is required to provide the necessary energy input. Normal natural gas furnaces, whirh have a honnet temperature of around $140^{\circ} \mathrm{F}$, are able to supply the heating energy with a much lower air flowrate. The same is true for normal air conditioners which operate at lower temperatures. Therefore, what the heat pump system gives up in terms of higher operating temperature is made up for by an increase in air volume flowrate.

Table 13 shows a copy of the system load summary for the heat pump system. It can be seen that the annual heating energy supplied by the heat pump is significantly less than the energy supplied by the other two systems. While the UHT and the SZRH systems are almost identical in both the monthly total energy supplied and the hourly peak energy supplied during the month, the heat pump system totals consistently about half as much as the other systems in these categories. The values for the annual heating energy supplied by the UHT and SZRH systems are -114.717 MBTU and -115.107 MBTU respectively while the heat pump system sums to only -54.811 MBTU per year. This can be explained by the fact that in the heating mode of operation, as the temperature of the heat source drops, a heat pump's ability to supply heat decreases. In the case of this simulation, the heat source is the outside air and as it approaches a temperature of around $30^{\circ} \mathrm{F}$, the heat pump reaches a point where it 
can no longer supply $100 \%$ of the building's heating demand. The cooler the ambient environment becomes; the less heat the heat pump is able to make available. Because of this fact, it would be necessary to consider a supplementary heat source to contribute additional heat when the heat pump is unable to supply the total load, if one were contemplating installing a heat pump as the primary heating supply system. 
TABLE 8. Unit heater system design parameters

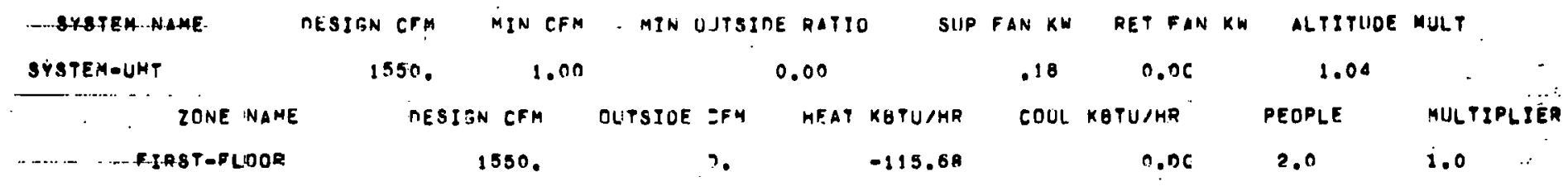

TABLE 9. Unit heater system load summary

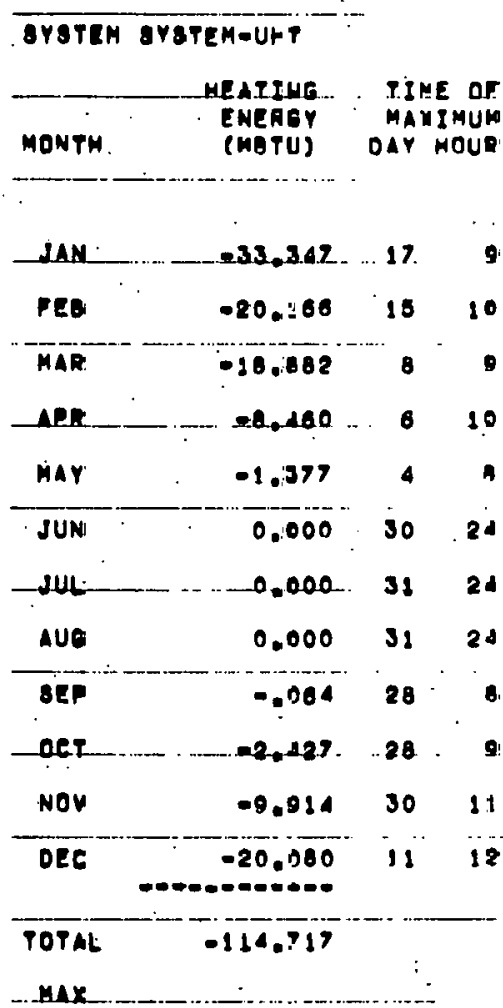

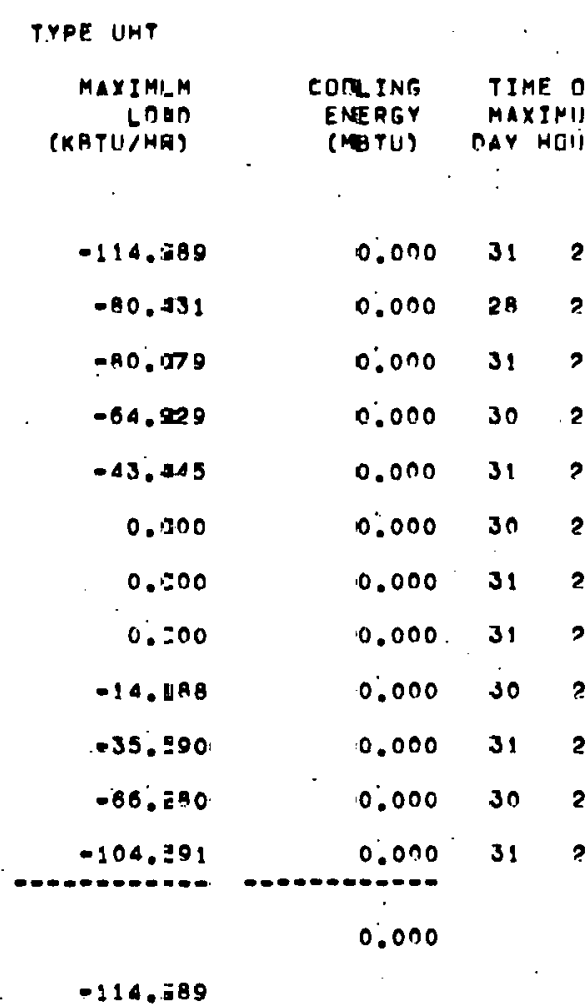

MAXIMUM
LOAD
(KBTUIHR)

$\begin{array}{cr}\text { ELECTRICAL. } & \text { MAXIMUM } \\ \text { ENERGY } & \because \text { LOAD } \\ \text { (KWH) } & \text { (KW) }\end{array}$

0.000
0.000
0.000
0.000
0.000
0.000
0.000
0.000
0.000
0.000
0.000
0.000
0.00
0.000

2119.

1914.

2119.

2050.

2119.

$205 n$.

2119.

2119.

2050.

2119.

2050.

2119.

24347.086 
TABLE 10. Single zone fan system design parameters

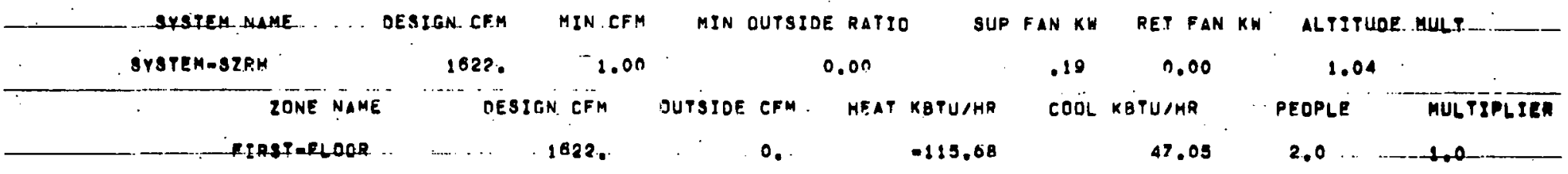

TABLE 11. Single zone fan system load summary

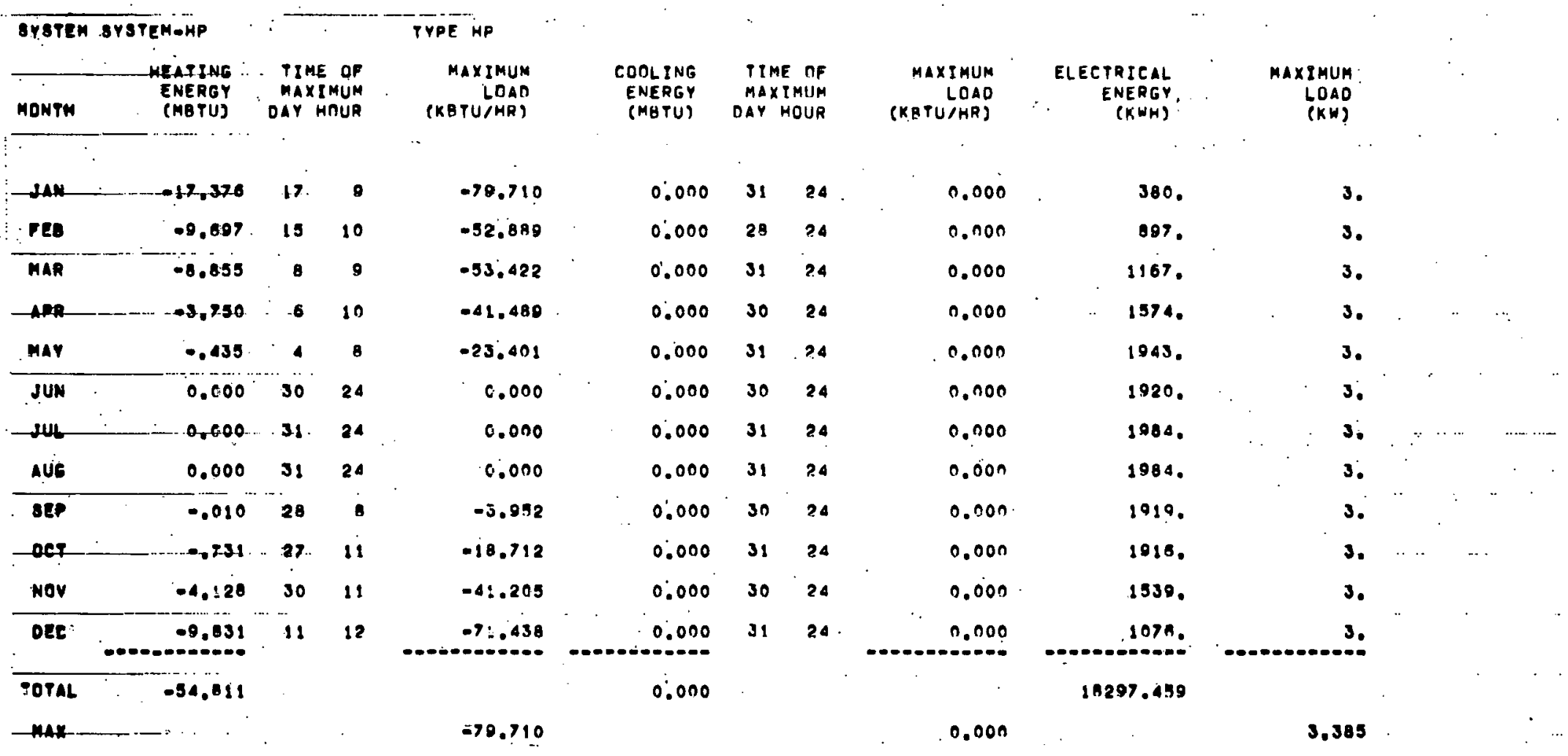


TABLE 12. Heat pump system design parameters

\begin{tabular}{|c|c|c|c|c|c|c|c|c|c|c|}
\hline SYSFEM-NAME. & OESIGN CFM & MIN EF: & $M P N$ & DUTSINE & RATIO & sup & FAN KW & RET FIN KW & ALTITUDE & MUL.T \\
\hline BYATEM=HP & 5668. & 1.00 & $\cdot$ & & .00 & & .00 & 2.00 & 1.04 & \\
\hline ZONE NAME & DESIGN & N. CFM & DU'SIDE & CFiA & HEAT I & KET J/HR & COOL & KBTUARR & PEOPLE & MULTIPLIER \\
\hline CIRST-FL00R. & 5 & 3668. & & n. & . & -115.68 & & $47 . n 5$ & 2.0 & 1.0 \\
\hline GARAGE & & 0. & . & 0. & & $0.0 \mathrm{P}$ & & 0.00. & 0.0 & 1.0 \\
\hline
\end{tabular}

TABLE 13. Heat pump system load summary

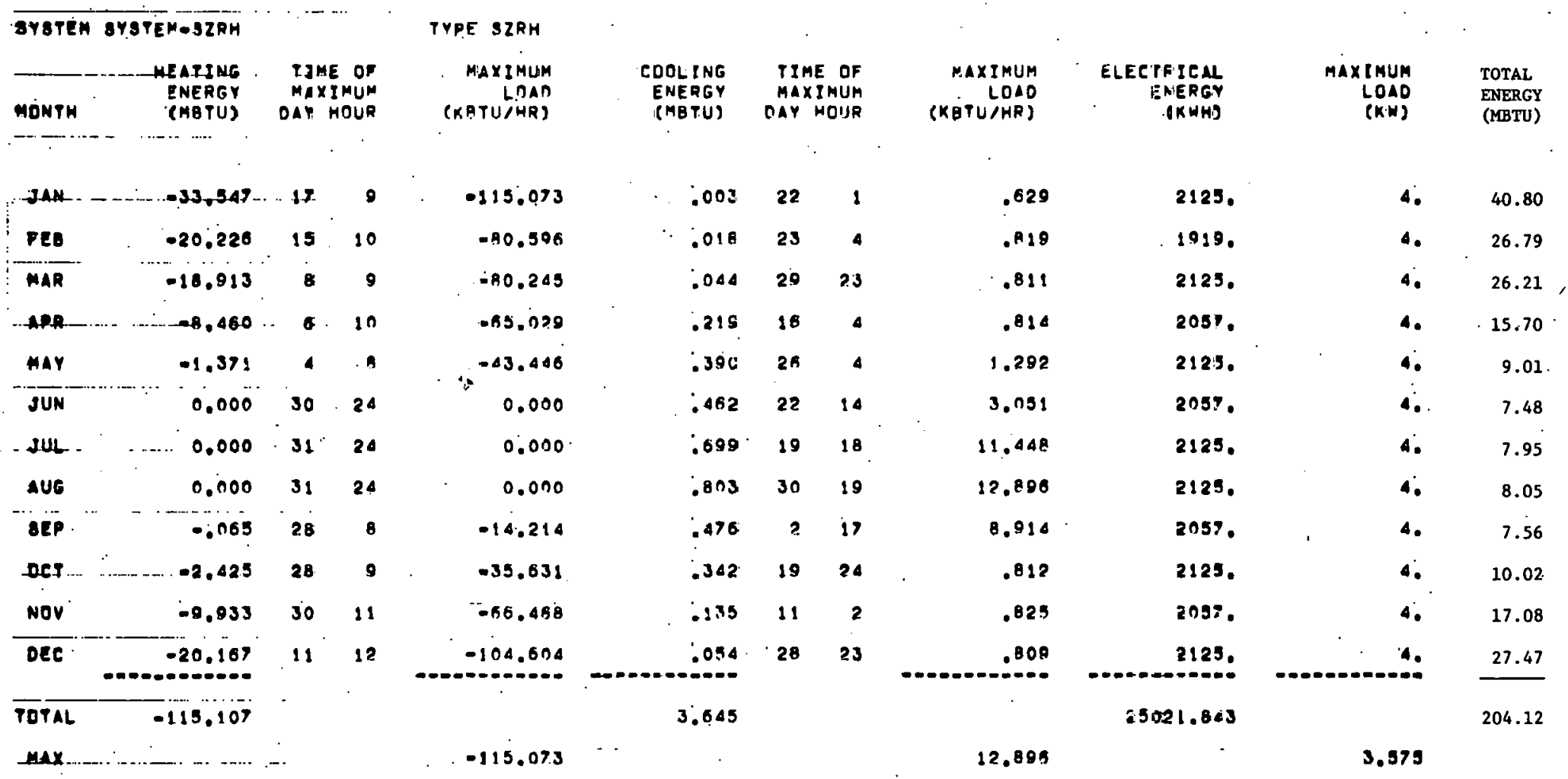


PLANT EQUIPMENT SIMULATION

The PLANT portion of the DOE-1 computer program simulates the operation of the "primary" energy conversion equipment used to supply heating

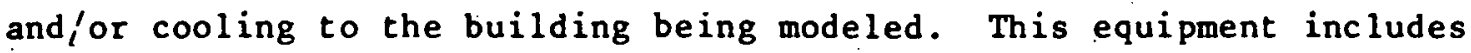
such items as steam and electric boilers for heating, absorption and compression chillers for cooling, heat recovery devices, cooling towers for the dissipation of unnecessary energy, electrical generation equipment for on-site production of electrical power, storage tanks, and various solar systems for the simulation of this alternative resource. Not only does the PLANT program provide equipment operation statistics, it also calculates a series of plant equipment economic statistics. The initial costs, subsequent replacement costs, and residual value for unused equipment life are combined to calculate the investment in plant equipment. Annual maintenance, periodic overhauls, and energy costs are used to predict savings from a particular plant design. The results of these calculations are then passed on to the ECONOMICS program where they are combined with costs related to non-plant components (such as HVAC systems, insulation, and other building construction components not included as part of the primary energy converoion plant) to obtain an economic summary. The final result is a complete energy profile for a particular energy supply system. However, the PLANT program itself is only concerned with the simulation of energy conversion equipment and the economic factors associated with that equipment.

The basic premise behind the utilization of the PLANT program is to allow the user to compare several different plant designs. The user can make a number of PLANT runs that each simulate a different size or type of equipment. In this way the output can be used to "zero" in on the 
optimal arrangement that is most beneficial for that particular building. While this describes the basic intent for the use of the PLANT program, this study utilizes this section of DOE-1 for a simulation of the present heating and cooling plant only. As indicated earlier, the intended comparison with the solar plant was impossible since this portion of DOE-1 is inoperative at present.

The test house as currently constructed utilizes a conventional natural gas furnace located in the basement with forced air ductwork for heating. Output capacity from the furnace is $130,000 \mathrm{BTU} / \mathrm{HR}$ with a half horsepower fan for distribution of the heat. A central air conditioning unit rated at a capacity of 30,000 BTU/HR supplies the cooling needs for the house. Unfortunately, at the current time there is no means for simulating a gas furnace within the DOE-1 program, although plans are for inclusion of this alternative in the future. Due to this deficiency it was necessary to model the house's heating plant as a steam boiler. All input data (plant size, fuel costs, etc.) is based as close as possible on the gas furnace plant now in the house. In this way it was hoped that, although the actual simulation is for a steam boiler, the results may be soméwhat reasonable based on the input being taken from actual conditions. The air conditioning system is modeled as is. Figures 27 and 28 are diagrams of the input/output for the steam boiler and air condirinner systems respectively.

Output from the PLANT program simulation consists of a series of tables which express the performance characteristics of the plant as indicated by the user. Tables 14 through 22 are copies of the PLANT printout pages for the test house as simulated with the steam boiler heating plant and the central air conditioning cooling plant. The first table is a summary of the energy utilized by the central plant for each month of the 


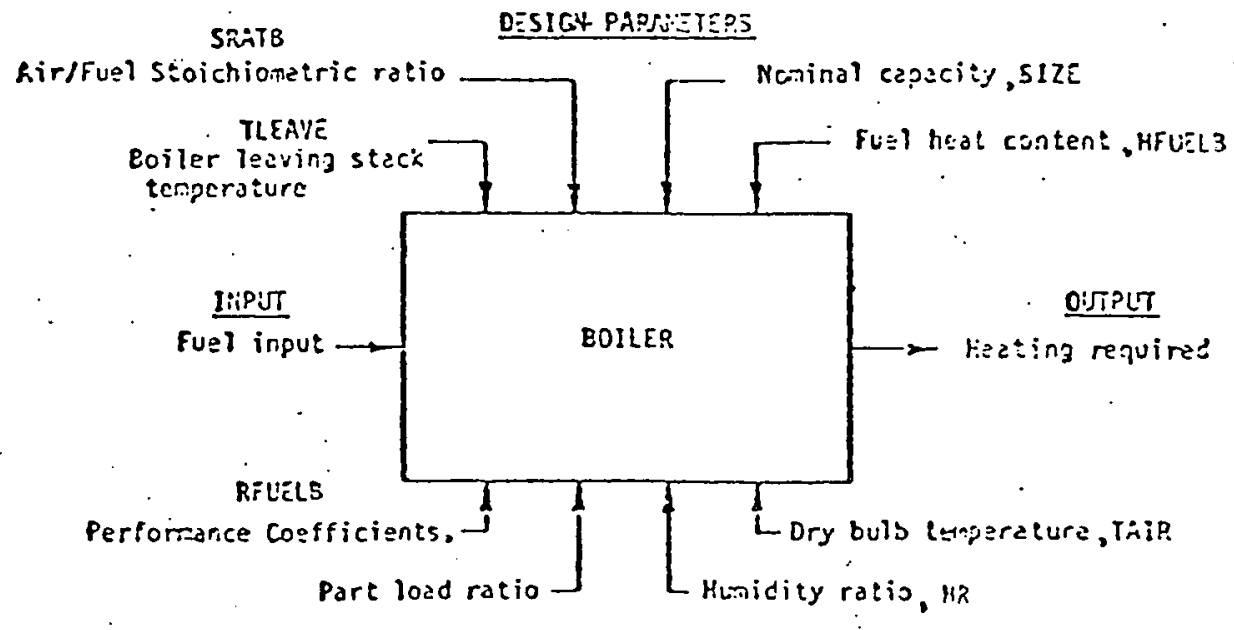

INPUT PADAYETERS

Fig. 27. Steam boiler

DESIGII PARRIETERS

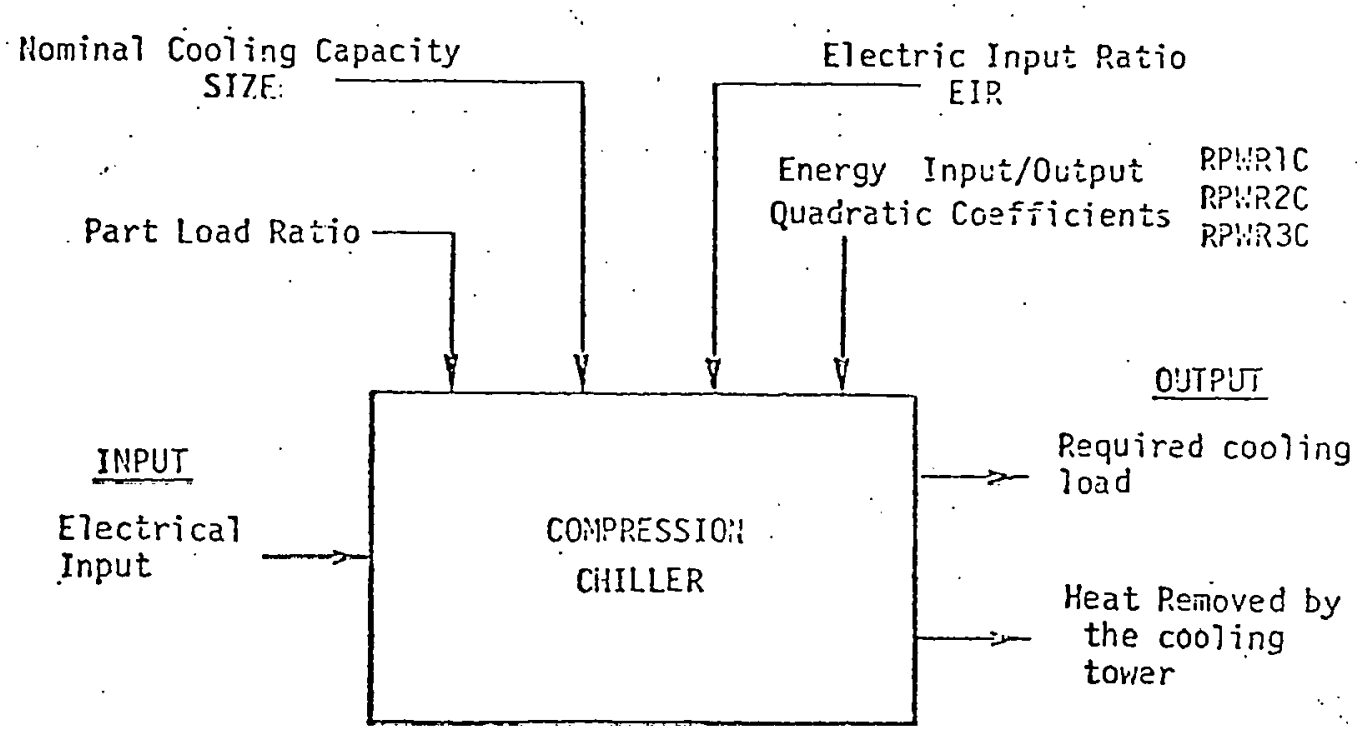

Fig. 28. Air conditioner compression chiller 
year. All values are in giga-BTU (billion) except for the last column on the table which is a percentage figure. Probably the most revealing columns on this table are the last two. The total energy input is the sum of the electrical and natural gas fuel energy used by the plant in its performance of conditioning the building. The average plant efficiency is found by dividing this total energy input value by the energy supplied to the building by the energy distribution system, which is found on Table 11 . This represents a conversion loss as energy in the raw form (natural gas or electricity) is converted to conditioned air for the buflding. The plant efficiencies range from $56 \%$ in January when there is only heating demand to $33 \%$ in June, July, August, and September when the cooling demand is predominant. Part of this low efficiency is due to the necessity of modeling the house's heating plant as a steam boiler instead of the actual natural gas forced air furnace. Typically home gas furnaces operate in the range of $75 \%$ to $80 \%$ efficiency in converting natural gas to usable heat energy. Most of the loss may be attributed to stack losses and low efficiency during heat up and cool down périods. A furnace will operate at a much lower efficiency if it is constantly cycling on and off rather than running more continuously for a longer period of time. In addition, it is interesting to note the relatively low efficiency of the air conditioning unit in converting electrical energy. to cooling supply. Not reflected in this value is the low efficiency of power plants in converting chemical or nuclear energy to electricity (around $33 \%$ ). If this were included, the final end efficiency would be subtantially decreased.

Table 17 shows the monthly peak and total energy use summary for the plant simulation. The interesting figures in this table are the total energy use of $279.080 \mathrm{MBTU}$ and total energy cost of $\$ 800$. The 
total use as calculated by the PLANT program is significantly higher than the actual average annual energy use of 195.456 MBTU obtained from utility bills. This can be explained again by the need to model the house's heating plant as a steam boiler. Due to its lower efficiency (50-56\% as indicated by Table 14), this type of plant requires more fuel to provide the same heating energy as a gas furnace. Thus the increased fuel usage calculated here. However, the calculated total cost of $\$ 800$ for annual fuel needs is close to the actual energy cost of $\$ 820.81$ determined from the 1977 utility bills. This $2.5 \%$ difference can easily be explained by the fact that energy cost data included in the PLANT input is in the form of average costs which leads to the slight disparity between the two cost figures.

Table 18 shows the equipment operation statistics for the heating and cooling plant. Note the large number of hours when the plant operates at a low percent of capacity. This is a result of the necessary practice of sizing heating and cooling equipment to meet the highest peak demand. Because this peak may occur only once in a year or once in several years, the equipment is oversized relative to normal or average conditions. Therefore, the vast majority of operating time io spent at the luwer end of the percent capacity spectrum as reflected by Table 18. This is most graphic in the case of the air conditioning unit where over $98 \%$ of the operating hours are spent between 0 and $10 \%$ of rated capacity. The low efficiency of the air conditioner can also be seen in this table. Total operating hours number 4862 to produce a total load of only .015 GBTU. This is contrasted by the steam boiler which requires only 3898 operating hours to supply the required heating load of $.115 \mathrm{GBTU}$. It should be noted that this does not necessarily reflect efficiency in 
terms of fuel conversion but does indicate a measure of efficiency in terms of operating time to produce the required load which can be an indirect measure of overall efficiency.

Table 19 indicates that the plant equipment as simulated is large enough to satisfy $100 \%$ of the total heating and cooling demand. This, along with Table 20 which shows the overload of plant equipment if there is any, can be an important factor in determining plant size. As mentioned carlier, plants must be oversized tó a certain degree to account for peak loads. An undersizing of any particular plant will be reflected in these two tables and allows the user to make adjustments in the plant capacities to compensate for this overloading. 
TABLE 14. Central plant energy utilization summary

\begin{tabular}{|c|c|c|c|c|c|c|c|c|c|c|c|c|}
\hline MONTH & $\begin{array}{l}\text { TOTAL } \\
\text { HEAT } \\
\text { ENEQGY } \\
\text { SEBTUS }\end{array}$ & $\begin{array}{l}\text { TOTAL } \\
\text { ELECYR } \\
\text { ENERGY } \\
\text { (JBYU) }\end{array}$ & $\begin{array}{l}\text { COOLING } \\
\text { ENERGY } \\
\text { (GATU) }\end{array}$ & $\begin{array}{l}\text { RCIRED } \\
\text { ENERGY } \\
\text { (GRTU) }\end{array}$ & $\begin{array}{l}\text { WASTED } \\
\text { RCVRABL } \\
\text { ENERGY } \\
\text { (GBTU) }\end{array}$ & $\begin{array}{l}\text { HEAT. EN } \\
\text { INPUT } \\
\text { COOLING } \\
\text { PGSTU) }\end{array}$ & $\begin{array}{l}\text { FLEC EN } \\
\text { INPUT } \\
\text { COOLING } \\
\text { (GBTU) }\end{array}$ & $\begin{array}{l}\text { ENERGY } \\
\text { INPUT } \\
\text { HEATING } \\
\text { (GATUS }\end{array}$ & $\begin{array}{l}\text { ENERGY } \\
\text { INPUT } \\
\text { ELECTRE } \\
\text { (TBTU) }\end{array}$ & $\begin{array}{l}\text { TOTAL } \\
\text { FUEL } \\
\text { INPUT } \\
\text { (GBTU) }\end{array}$ & $\begin{array}{l}\text { TOTAL } \\
\text { ENERGY } \\
\text { INPUT } \\
\text { (GBTU) }\end{array}$ & $\begin{array}{l}\text { AVERAGE } \\
\text { PLANT } \\
\text { EFFIC } \\
\text { (PERET) }\end{array}$ \\
\hline 1 & .034 & .007 & .000 & 0.000 & 0.000 & 0.0 no & .000 & $\begin{array}{r}.051 \\
.00\end{array}$ & .022 & .051 & .074 & $\begin{array}{l}58 . \\
58.00\end{array}$ \\
\hline--2 & .020 & م02. & .000 & 0.000 & 0.000 & 0.000 & .000 & .033 & .120 & .033 & .053 & 51. \\
\hline 3 & .019 & . & .000 & $0.000^{\circ}$ & 0.000 & $0.0 \cap 0$ & .000 & .031 & $.02 ?$ & .031 & .053 & 49. \\
\hline 4 & $.00 B$ & . 008 & $.0 n 0$ & 0.000 & 0.000 & 0.000 & .001 & .014 & .023 & .014 & .037 & 43. \\
\hline - & .001 & -1008 & .000 & 0.000 & 0.000 & 0.000 & .002 & .003 & .024 & $.00 \mathrm{~s}$ & .027 & 35. \\
\hline 6 & 0,000 & .008 & .000 & 0.00 .0 & 0.000 & $0.0 \cap 0$ & .003 & $0.0 n 0$ & .024 & $0 . n 00$ & .024 & 33. \\
\hline 7 & 0.000 & .008 & $.0 n 1$ & 0.000 & 0.000 & $0.0 n 0$ & .003 & 0.000 & .025 & 0.000 & .025 & 33. \\
\hline 0 & 0.000 & .008 & .001 & 0.000 & 0.000 & 0.000 & .003 & 0.000 & .025 & 0.000 & .025 & 33: \\
\hline 9 & .000 & $.00 B$ & .000 & 0.000 & $n .000$ & 0.000 & .003 & .000 & .024 & .000 & .024 & 33. \\
\hline 10 & .002 &.$D O B$ & .000 & 0.000 & 0.000 & 0.000 & .002 & .004 & .024 & .004 & .028 & 37. \\
\hline 11 & -0.020 & .007 & .000 & 0.000 & 0.000 & 0.000 & .001 & .017 & .022 & .017 & .039 & 44. \\
\hline 12 & .020 & . 07 & .000 & 0.000 & $n, n o n$ & $0.0 n 0$ & $.00 n$ & .0 .33 & .022 & .03 .3 & .055 & 50. \\
\hline & $\begin{array}{r}=80118 \\
.115\end{array}$ & 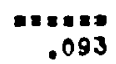 & $\begin{array}{r}=040.38=8 \\
.004\end{array}$ & $\begin{array}{r}=E 1.28 z \\
0.000\end{array}$ & 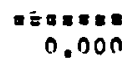 & 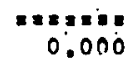 & $\begin{aligned} A=8 & =8 x=8 \\
& 01019\end{aligned}$ & $\begin{array}{r}=808288 \\
.187\end{array}$ & $\begin{array}{r}=02808 \\
\quad .278\end{array}$ & $\begin{array}{r}=80188 \\
.187\end{array}$ & $\begin{array}{l}.84=0 \\
.464\end{array}$ & 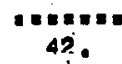 \\
\hline
\end{tabular}


TAE-E 15. Equipment use statist:cs

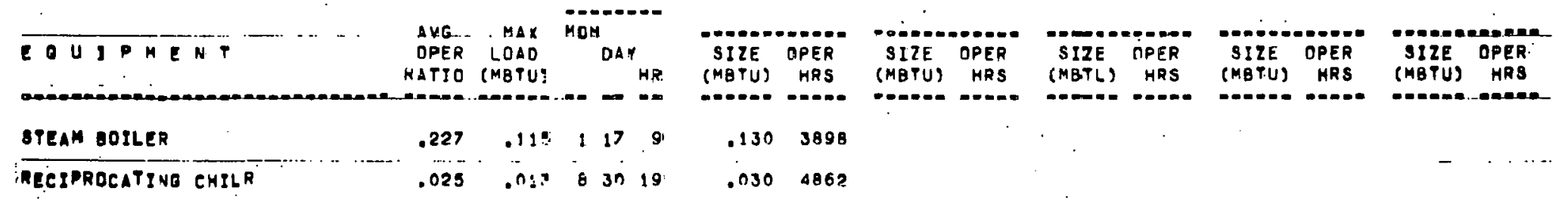

TA3LE 16. Central plant life cycle equipment cost summary

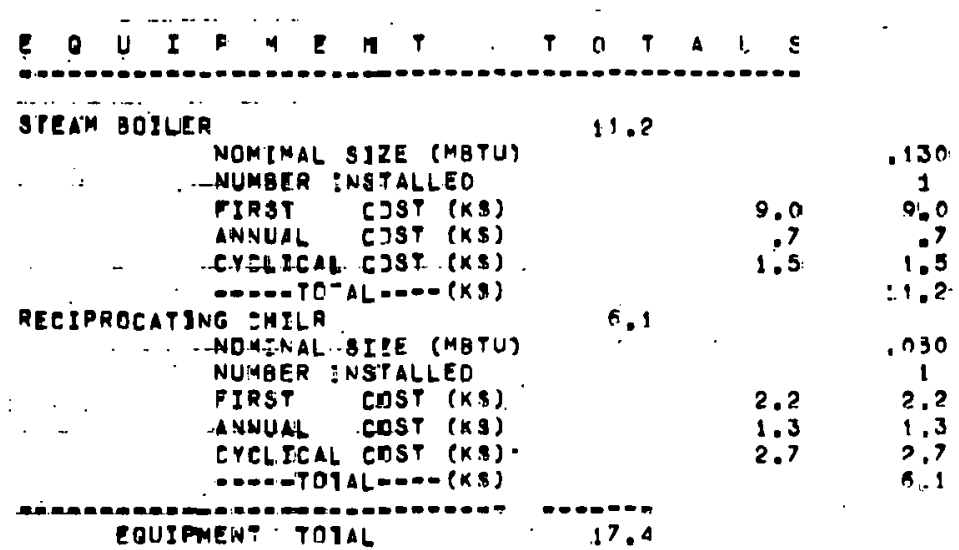


TABĹE 17. Monthly peak and total energy use summary

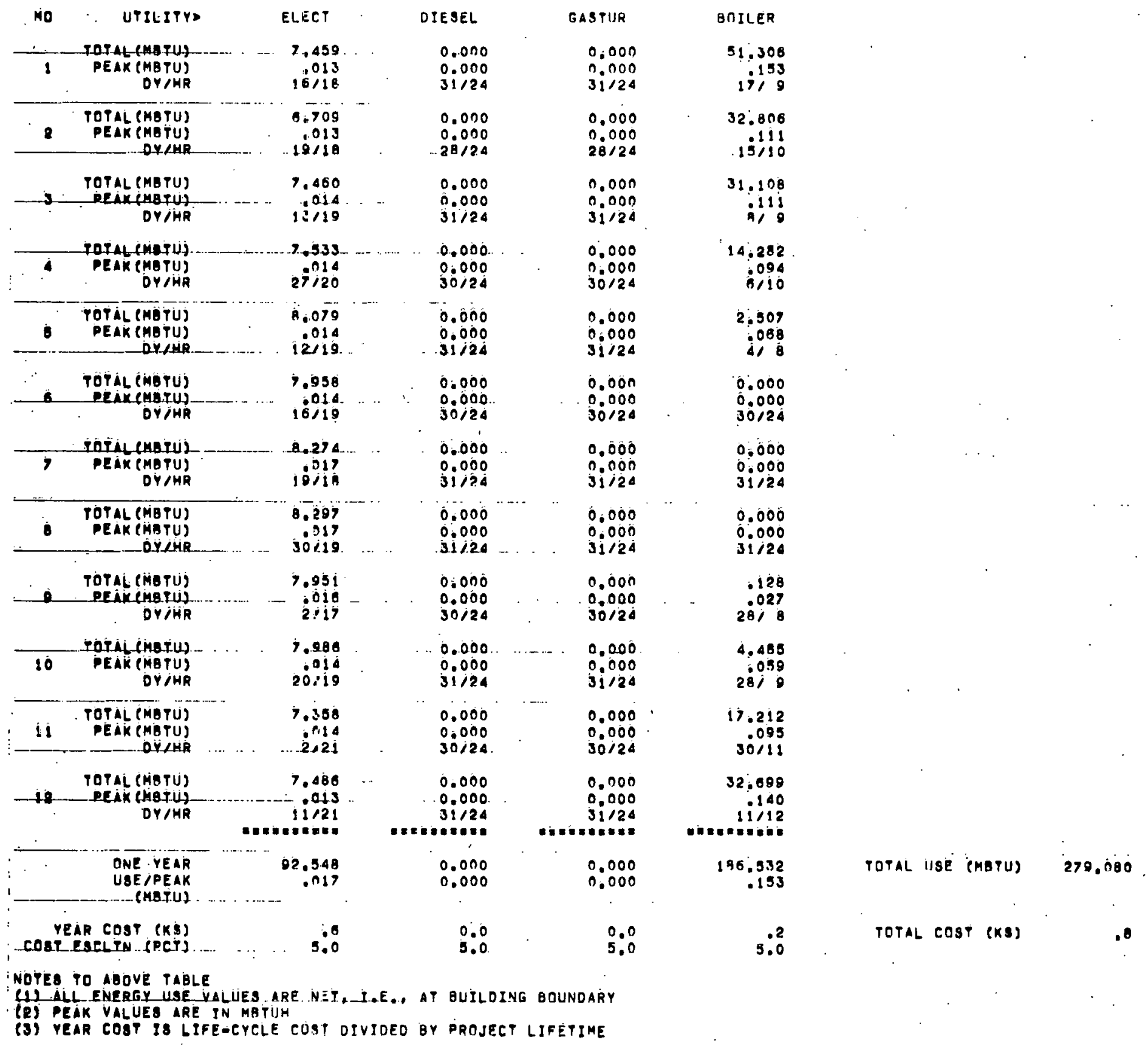


TABLE 18. Eçipment operation and part load report

\begin{tabular}{|c|c|c|c|c|c|c|c|c|c|c|c|c|c|c|c|c|}
\hline NAME & & $\cdots$ & & MOURS & $S A T P E$ & ERCEN" & FARP $P$ & LOAD RL & ATSO & & & & $\begin{array}{l}\text { TnTel } \\
\text { HOU }=\mathrm{s}\end{array}$ & $\begin{array}{l}\text { ANNUAL } \\
\text { LOAD } \\
\text { (GBTU) }\end{array}$ & $\begin{array}{l}\text { FALSE } \\
\text { LOAD } \\
\text { (GBTU) }\end{array}$ & $\begin{array}{r}\text { TOTAL } \\
\text { LOAD } \\
\text { CGOTU) }\end{array}$ \\
\hline -erma & $\begin{array}{c}0.10 \\
017 \\
017\end{array}$ & $\begin{array}{l}970^{20} \\
972\end{array}$ & $\begin{array}{l}8.30 \\
840 \\
840\end{array}$ & $\begin{array}{l}-040 \\
640 \\
640\end{array}$ & $\begin{array}{l}-550 \\
354 \\
354\end{array}$ & $\begin{array}{l}-106 \\
106 \\
106\end{array}$ & $\begin{array}{c}-.70 \\
43 \\
43\end{array}$ & $\begin{array}{c}0.1^{R O} \\
19 \\
19\end{array}$ & $\begin{array}{c}-90 \\
7\end{array}$ & $=0_{0}^{100}$ & $\begin{array}{l}-110 \\
0\end{array}$ & $\begin{array}{l}-12 n+ \\
0 \\
0\end{array}$ & 3398 & .115 & 0.000 & 115 \\
\hline COMRR & $-\frac{17.24}{d 774}$ & -3e & $\begin{array}{r}-28 \\
-28\end{array}$ & $18 \cdots$ & 4. & 0 & 0 & $\begin{array}{l}0 \\
0\end{array}$ & $\begin{array}{l}0 \\
0\end{array}$ & $\begin{array}{l}0 \\
0\end{array}$ & $\begin{array}{l}0 \\
0\end{array}$ & $\begin{array}{l}0 . \\
0\end{array}$ & $496 ?$ & .004 & .011 & .015 \\
\hline
\end{tabular}

1) THE FERST PART LOAD ENTRY FOR RACH PIECE OF EOUIPMENT IS A FUNETION

DF THE HOURLY OPEFITING CAPACITY CUNITS OPERATING THAT HOUR) 2). THE SECOND PART LOAD ENTRY FOR EACH PIECE DF EOUIPHENT IS A FUNCTION

TABLE 19. Plant demands satisfied report

\begin{tabular}{|c|c|c|}
\hline $\begin{array}{l}\text { MEATINE DEMANOS } \\
\end{array}$ & $\begin{array}{l}\text { GBTU SUPPLIED } \\
\text { G. }\end{array}$ & $\begin{array}{l}\text { PCT OF TOTAE PEMANJ } \\
\text { POANA }\end{array}$ \\
\hline STEAM BOILEF & 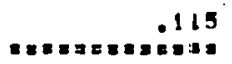 & $\begin{array}{l}900.0 \\
\cos \end{array}$ \\
\hline $\begin{array}{l}\text { DEMANM SATESFIED } \\
\text { TOTAL DEMANO ON PLANT }\end{array}$ & .115 & 100.9 \\
\hline CUOLENG OEMAKDS & GBTU SUPPLIEn & PCT OF TOTA. JEMAND \\
\hline RECIPROCATIWE EHILR & 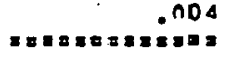 & 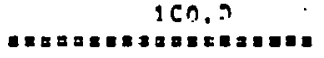 \\
\hline $\begin{array}{l}\text { DEMAND SATISFIEN } \\
\text { TDTAL DEMAND DN FLANI }\end{array}$ & .004 & $100: 0$ \\
\hline $\begin{array}{l}\text { ELECTRICAL. DEMAN.IS } \\
-\end{array}$ & $\begin{array}{l}\text { GBTU SUPPLIED } \\
-\end{array}$ & PCT OF, TOTAL DEMAND \\
\hline . & 8000001808008 & 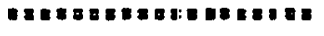 \\
\hline $\begin{array}{l}\text { DEMAND GATISFIED } \\
\text { TOTAL. DEMANE ON PLAN- }\end{array}$ & $\begin{array}{r}0 . \operatorname{con} \\
. \cos 3\end{array}$ & $n .0$ \\
\hline $\begin{array}{l}\text { PEJECTED HEAT } \\
\text { SESTE }\end{array}$ & $\begin{array}{l}\text { GBTU SUPPLIEN } \\
\text { G }\end{array}$ & $\begin{array}{l}\text { PCT OF TOTAL OEHAHD } \\
\text { PIL }\end{array}$ \\
\hline & 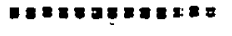 & 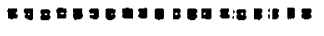 \\
\hline $\begin{array}{l}\text { DFMAND SATIS = IED } \\
\text { TOTAL OEMANG C.N OLANI }\end{array}$ & $\begin{array}{r}0.000 \\
.010\end{array}$ & $n, n$ \\
\hline
\end{tabular}


TABLE 20. Summary of loads met

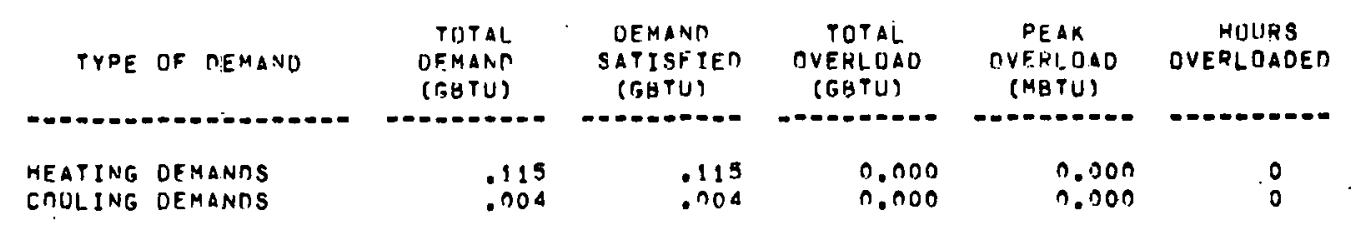

TABLE 21. Electrical demand scatter plot

TOTAL HOIJR AT DEMANO INO TIME OF OAY

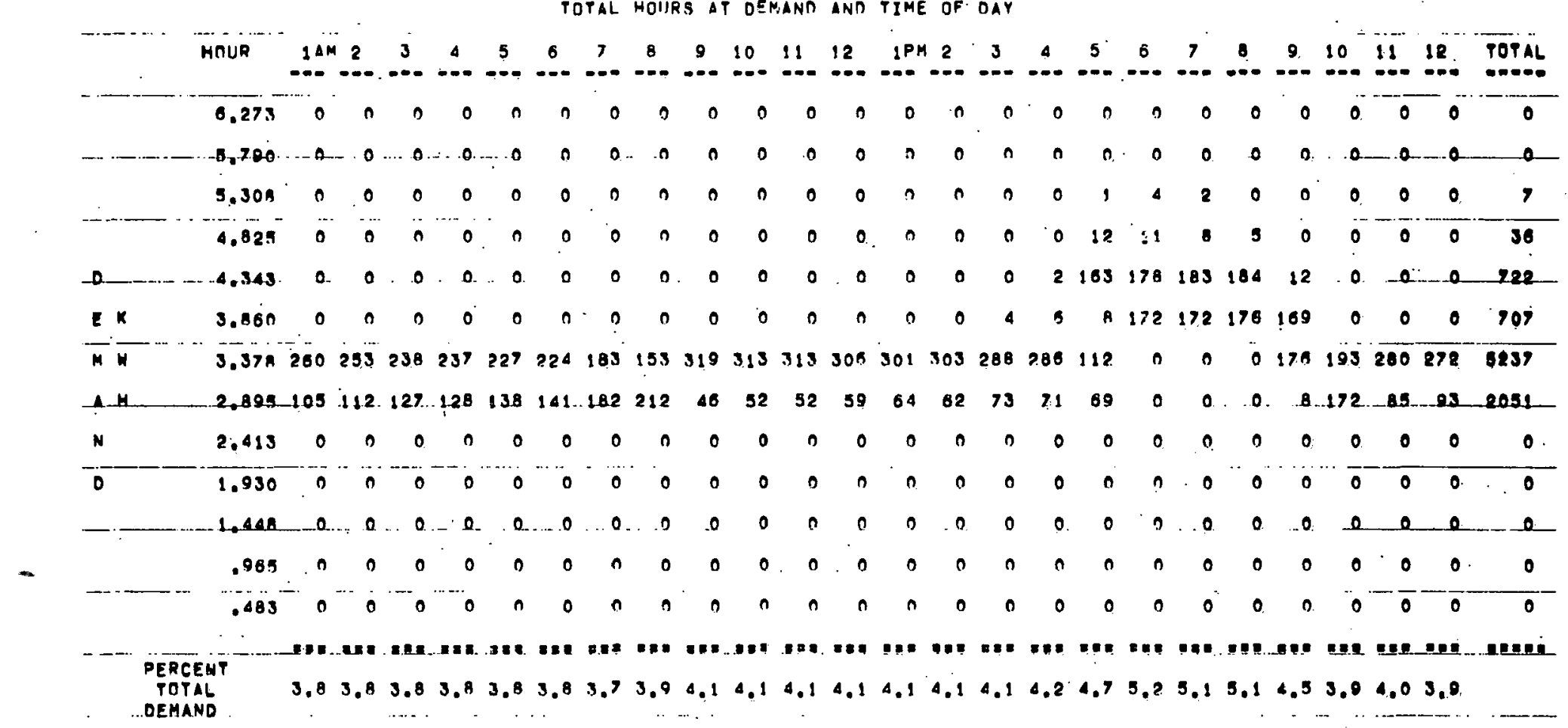

PEAK ELECTRICAL LOAD BREAKDOWN

\begin{tabular}{|c|c|c|}
\hline SOURCE & $\begin{array}{c}K W H \\
0.0 .0 .\end{array}$ & $\begin{array}{l}\text { PCT } \\
-\end{array}$ \\
\hline $\begin{array}{l}\text { SYSTEMS LOAD } \\
\text { COMPRESSION CHILLERS } \\
\text { COOLING TOWER } \\
\text { CIRCULATION PUMPS }\end{array}$ & $\begin{array}{r}3.574 \\
1.272 \\
.096 \\
.068 \\
0.000 .001\end{array}$ & $\begin{array}{r}71.9 \\
25.5 \\
1.3 \\
1.4\end{array}$ \\
\hline TOTAL & 4.990 & \\
\hline
\end{tabular}


TABLE 22. Life-cycle plant cost summary

ELANR LOUIEMENT COSF
ENERG COST:
ENERBY USE (NET)

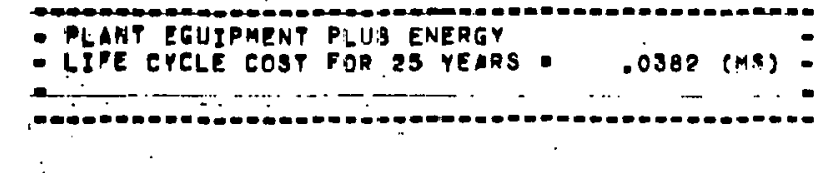

- LIFE CYCLE COST FOR 23 YEARS - .0382 (MS):

$+-$

NOTES TO MOOVE TABLE

(1) AMUWAL OUANTITIES ARE LJFERCYCLE YILUES DIVIOED BY PROJECT LIFETIME

(2) EMERGY USE IS NEP, I.E., AT BUILOING BOUNOARY 


\section{ECONOMICS}

As mentioned in the description of the DOE-1 computer program, the ECONOMICS program is used to compute various building cost parameters based on information supplied by the LOADS, SYSTEMS, and PLANT programs as well as input from the user. The life-cycle costs of the energy conversion equipment (furnaces, chillers, etc.) are calculated in the PLANT program as indicated earlier. These plant life-cycle costs are for 1) purchasing, installing, and maintaining plant equipment and 2) the fuel and electricity used by the facility. The ECONOMICS program combines these PLANT results with non-plant life-cycle costs to obtain a total overall picture of the building's life-cycle costs. In this way the ECONOMICS program may be used to "predict" the economic operation of a particular building or, when baseline information is supplied, it may be used to compare several alternative approaches against the baseline conditions.

While it is not within the scope of this project to perform a thorough economic analysis for the test house, it was felt that a basic run of the ECONOMICS program should be included to illustrate' the usage of this portion of DOE-1. In the case of this project, the ECONOMICS program is simply used to obtain a rough life-cycle cost picture for the test house. Input into the program consists of : 1) a building first cost of $\$ 50,000 ; 2)$ an annual cost of $\$ 1000$ in terms of maintenance,. upkeep, and improvements; 3) a discount or interest rate of $10 \%$; and 4) a project life of 30 years. No comparison to a baseline is made so no baseline data is included.

Tables 23 through 25 are copies of the ECONOMICS output for this test. Table 24 shows the present value of non-plant 1 ife-cycle costs at 
88

a total of $\$ 59,430$. For the 30 -year lifetime of the building, non-plant costs, and fuel costs are summed to obtain a total overall life-cycle. cost of $\$ 97,700$ for the house. Table 25 shows both the comparison with the baseline (if one is made) and the savings to investment statistics for the house. These statistics are not as meaningful for this run as they would be for an actual economic comparison study using the baseline option. However, they do point out the power of the ECONOMICS program of DOE-1 for use in evaluating several building alternatives. 
TABLE 23. Economics verification

\begin{tabular}{|c|c|c|c|}
\hline $\begin{array}{r}\text { DISCOUNT } \\
\text { RATE } \\
\text { (PCT) }\end{array}$ & $\begin{array}{c}\angle A B O R \\
\text { INFL } \\
\text { (PATS }\end{array}$ & $\begin{array}{r}\text { MAIEKIALE } \\
\text { INFL -RATE } \\
\text { (PCT) }\end{array}$ & $\begin{array}{l}\text { PROJECT. } \\
\text { LIFETIME } \\
\text { (YRS) }\end{array}$ \\
\hline 10.0 & 0.0 & 0.0 & 30.0 \\
\hline
\end{tabular}

\begin{tabular}{|c|c|c|c|c|c|c|c|c|c|c|}
\hline COST-NAME & BUILOING-CNS & & NO. OF UNITS & 1. & UNIT - & NAME & & LIFER & & 099.0 \\
\hline $\begin{array}{l}\text { Fins } \\
\text { COST }\end{array}$ & $\begin{array}{l}\text { UNBT - } \\
\text { FIRST } \\
\text { COST }\end{array}$ & $\begin{array}{r}\text { INSTALL } \\
\text { :OST }\end{array}$ & $\begin{array}{r}\text { UNIT } \\
\text { INSTALL } \\
\text { COST }\end{array}$ & $\begin{array}{r}\triangle N N U A L \\
\text { COST }\end{array}$ & $\begin{array}{r}\text { IINIT } \\
\text { ANNUAL } \\
\text { COST }\end{array}$ & $\begin{array}{r}\text { MAINT } \\
\text { COST }\end{array}$ & $\begin{array}{l}\text { UNIT } \\
\text { MAINT } \\
\text { COST }\end{array}$ & $\begin{array}{l}\text { CONSUM } \\
\text { CUST }\end{array}$ & $\begin{array}{r}\text { UNIT } \\
\text { CONSUM } \\
\text { COST }\end{array}$ & \\
\hline 50000 . & 0.00 & 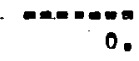 & 0.00 & lnon. & 0.00 & 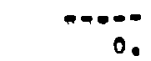 & 0.000 & $\cdots+\cdots$ & 0.00 & \\
\hline $\begin{array}{r}\text { CYELICAL } \\
\text { Cogst }\end{array}$ & $\begin{array}{c}\text { UNIT } \\
\text { EVELICAL } \\
\text { COST }\end{array}$ & $\begin{array}{r}\text { MIVUQR } \\
\text { NVHL-INT } \\
\text { (ITRS) }\end{array}$ & $\begin{array}{r}\text { MIN-OVHL } \\
\text { C.OST }\end{array}$ & $\begin{array}{c}\text { UNIT } \\
\text { MIN-OVHL } \\
\text { COST }\end{array}$ & $\begin{array}{c}\text { MAJOR } \\
\text { OVHL-INT } \\
\text { (YRS) }\end{array}$ & $\begin{array}{r}\text { MAJ }-O Y H L \\
\text { COST }\end{array}$ & $\begin{array}{r}\text { UNIT } \\
\text { MAJ }=\text { OVHL } \\
\text { COST }\end{array}$ & $\begin{array}{r}\text { REPLACE } \\
\text { COST }\end{array}$ & & \\
\hline 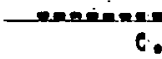 & 0.00 & $\begin{array}{r}x=-x=0 \\
0.00\end{array}$ & 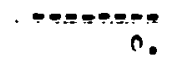 & $\begin{array}{r}n . n 0 \\
n\end{array}$ & $\begin{array}{r}0.00 \\
0.00\end{array}$ & $n_{0}$ & 0,00 & $n_{0}$ & & \\
\hline
\end{tabular}

TABLE 24. Life-cycle costs summary

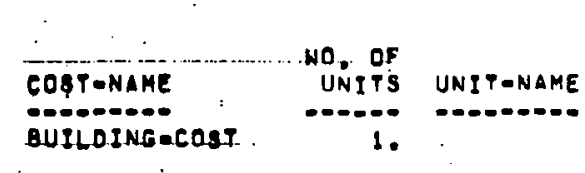

PRESENT-VALUE JF NON-PLANT LIFE-CYCLE COSTS (KS)

\begin{tabular}{|c|c|c|c|c|c|c|c|c|c|}
\hline $\begin{array}{l}\text { FIRST } \\
\text { COST }\end{array}$ & $\begin{array}{l}\text { INSTALL } \\
\text {-ATYOON }\end{array}$ & $\begin{array}{l}\text { POTAL } \\
\text { ANNUAL }\end{array}$ & $\begin{array}{l}\text { TUTAL } \\
\text { MAINT }\end{array}$ & $\begin{array}{c}\text { TOTAL } \\
\text { CONSUM }\end{array}$ & $\begin{array}{l}\text { TUTAL } \\
\text { CrCLIE }\end{array}$ & $\begin{array}{l}\text { MINDR } \\
\text { OVHLS }\end{array}$ & $\begin{array}{l}\text { MAJOR } \\
\text { OVHLS }\end{array}$ & $\begin{array}{l}\text { REPLACE } \\
\text {-MENTS }\end{array}$ & TOTAL \\
\hline & 0,00 & & 0.00 & 0.001 & 0.00 & 0.00 & 0.00 & 0.00 & 32.4 \\
\hline$=0.00$ & 0.00 & & in & 0.008 & 00 & 0.00 & 0.00 & 0.00 & \\
\hline
\end{tabular}

OVERALL LIFE-CYCLE COSTS (KS)

\begin{tabular}{rrrr} 
NONEPLANT & PLANT & FUEL & TOT L L \\
\hline 50.4 & 17.4 & 20.8 & 97.7
\end{tabular}


TAILE 25. Life-cycle savings/investment statistics

LIEE-CYCLE COMPARISON-- THYS KUN. VS BASELINE

\begin{tabular}{|c|c|c|c|c|c|}
\hline & $\begin{array}{l}\text { INVEST- } \\
\text { MENT (KS) }\end{array}$ & $\begin{array}{l}\text { PLANT-EQUIP } \\
\text { COST (KS) }\end{array}$ & $\begin{array}{l}\text { ENERGY } \\
\text { COST (KS) }\end{array}$ & $\begin{array}{l}\text { PLANT-EQUIP } \\
\text { ENERGY CDST (K\$) }\end{array}$ & $\begin{array}{l}\text { ENERG* } \\
\text { USE (GST'E) }\end{array}$ \\
\hline$\cdots$ & 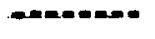 & 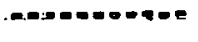 & $\infty n+\infty$ & 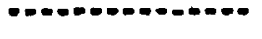 & - \\
\hline BASELIAE & & 0.00 & $n . n 0$ & 0.00 & $0.0=$ \\
\hline THIS RLN & 59.43 & 17.50 & 20.97 & 38.23 & $8.3 \%$ \\
\hline & & & & & \\
\hline S.AVINGS & & -17.36 & -20.87 & $-38 . ? 3$ & $-8.3=$ \\
\hline
\end{tabular}

$-17.36$

$$
-20.98
$$

$$
-38.23
$$

$-8.3=$

\section{S.IVINGSTINYEBTNENT STATISTICS}

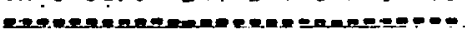

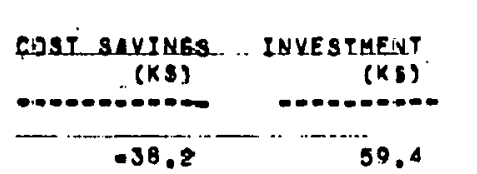

\section{SAVINGS-TH-}

INVESTMENT

RATIO

$-38,2$

59.0
A A INGS
(MBTU)

FUEL-SAVINGS-

TC-INVESTMEN

ATIO(MBTU/S)

$-.6 \quad-8372.4$

$-.: 4$

FYBACK

(YRSI

(YRS)

0.0 


\section{WEATHER DATA}

Weather is undoubtedly the single most influential factor affecting energy consumption by buildings. Because of this fact, weather data is extremely important in analyzing the energy consumption characteristics of any structure. The LOADS, SYSTEMS, and PLANT programs of DOE-1 each require hourly weather data contained in weather files to execute their. computations. These files contain one year ( 8760 hours) of climatic data for each of 60 U.S. weather stations. Weather variables included on these files are: 1) Drybulb Temperature, 2) Wetbulb Temperature, 3) Atmospheric Pressure, 4) Wind Speed, 5) Wind Direction, 6) Cloud Amount, 7) Cloud Type, 8) Dewpoint Temperature calculated from Drybulb and Wetbulb Temperatures, 9) Clearness Number, and 10) Ground Temperature. The particular year of weather data for each station is selected according to the ASHRAE (American Society of Heating, Refrigeration, and Air Conditioning Engineers) Test Reference Year (TRY) procedures.

The principle for selecting a TRY for any location is to eliminate years containing months with extremely high or low mean temperatures. Once the elimination procedure is completed, the lone remaining year becomes the TRY for that particular location. The period of examination for 59 of the $60 \mathrm{U} . \mathrm{S}$. weather stations is 1948-1975. The 60th station, Portland, Oregon has a period of record of 1949-1975. The weather station chosen for this energy consumption study is Cincinnati, Ohio and the TRY is 1957 .

It should be pointed out that the TRY is only a standard for comparing various heating and cooling systems or retrofit options. Therefore, it is not considered representative enough to yield actual energy peformance averages over several years. Weather data is so variable and exerts such 
a large influence on energy consumption that to base energy use estimates on a single year which contains no extreme climatic conditions would not be advisable. The following pages are a graphical representation of the 1957 TRY for Cincinnati used in this study. The variables not included on the diagrams (Wind Direction, Cloud Type, Clearness Number, and Ground Temperature) are nevertheless still on the weather files but have been eliminated from the graphs for brevity and clarity.

Also included are three diagrams illustrating lU-year average drybulb temperatures at Wright-Patterson Air Force Base located near Dayton, Ohio. This can serve as a check against which the TRY data may be compared. These graphs show that the most frequent wintertime temperature is $35^{\circ} \mathrm{F}$ and the most frequent summertime temperature is $72^{\circ} \mathrm{F}$ with extremes of around $-10^{\circ} \mathrm{F}$ and $100^{\circ} \mathrm{F}$ respectively. These values seem to coincide fairly fairly well with the TRY data of 1957 for Cincinnati although a much more thorough and extensive analysis would be necessary to firmly establish the similarity of the two sets of weather data. 


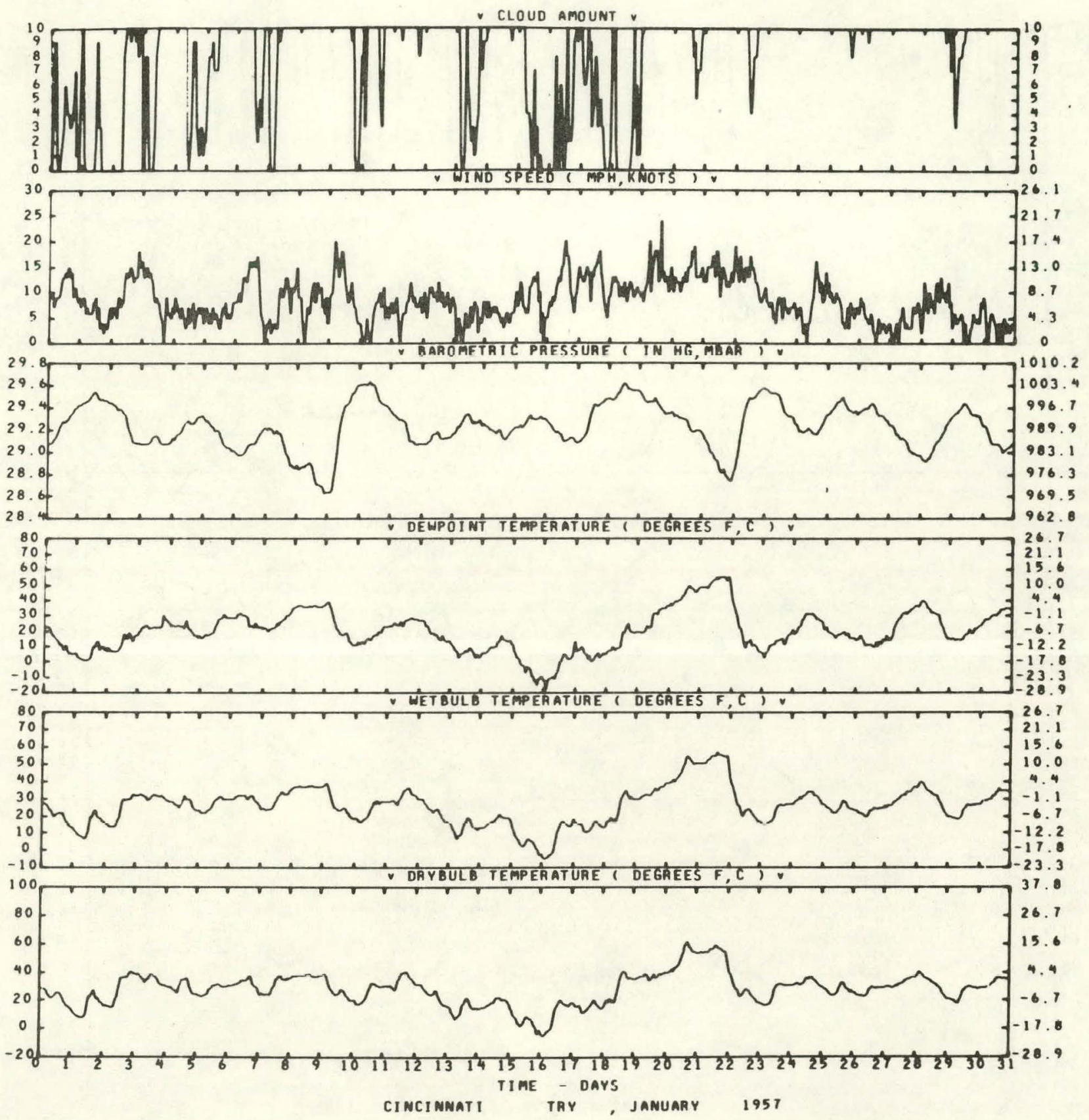

Fig. 29. 1957 TRY weather data for Cincinnati, Ohio (January-December) 


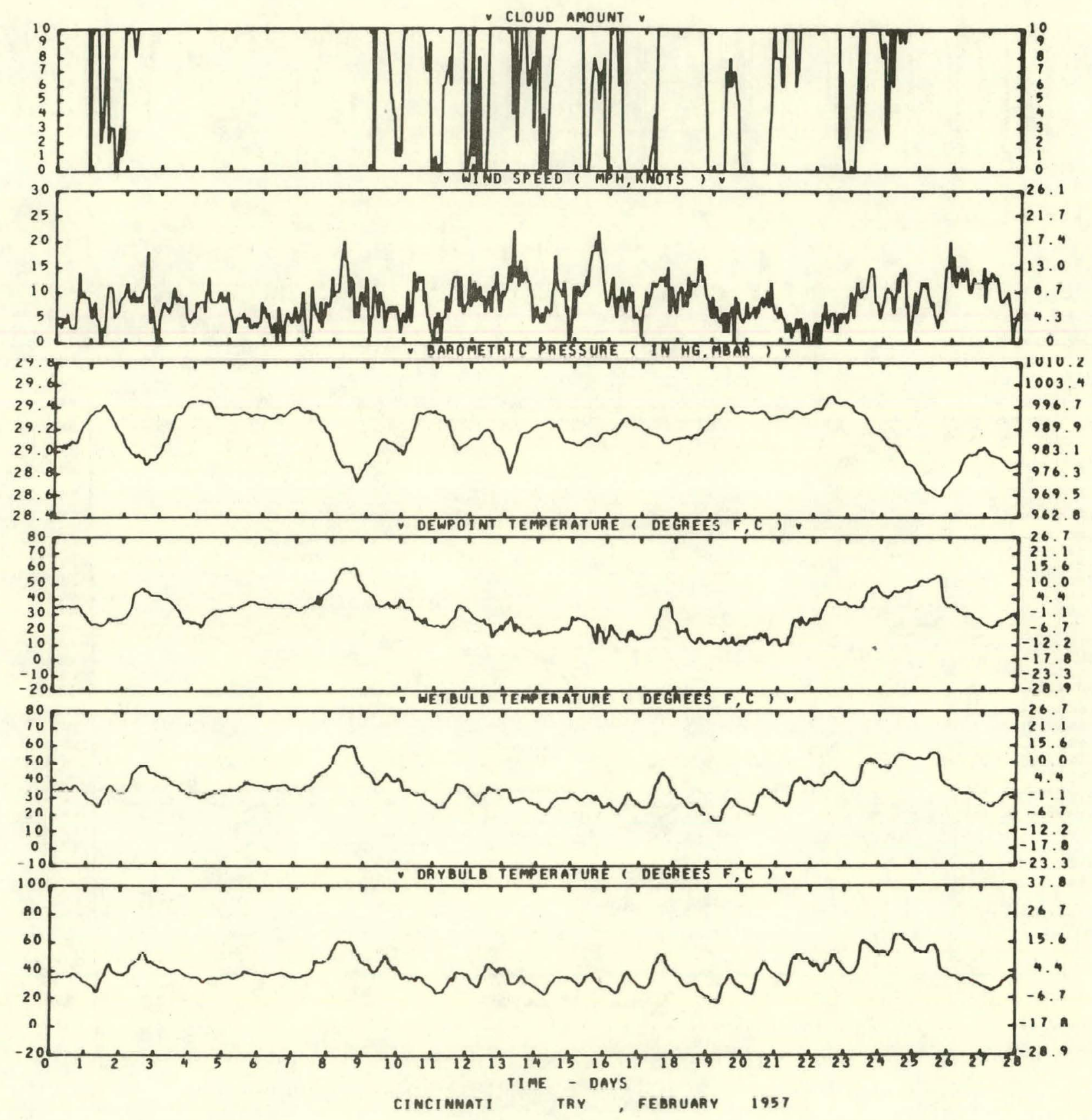

Fig. 29 (Contd.) 


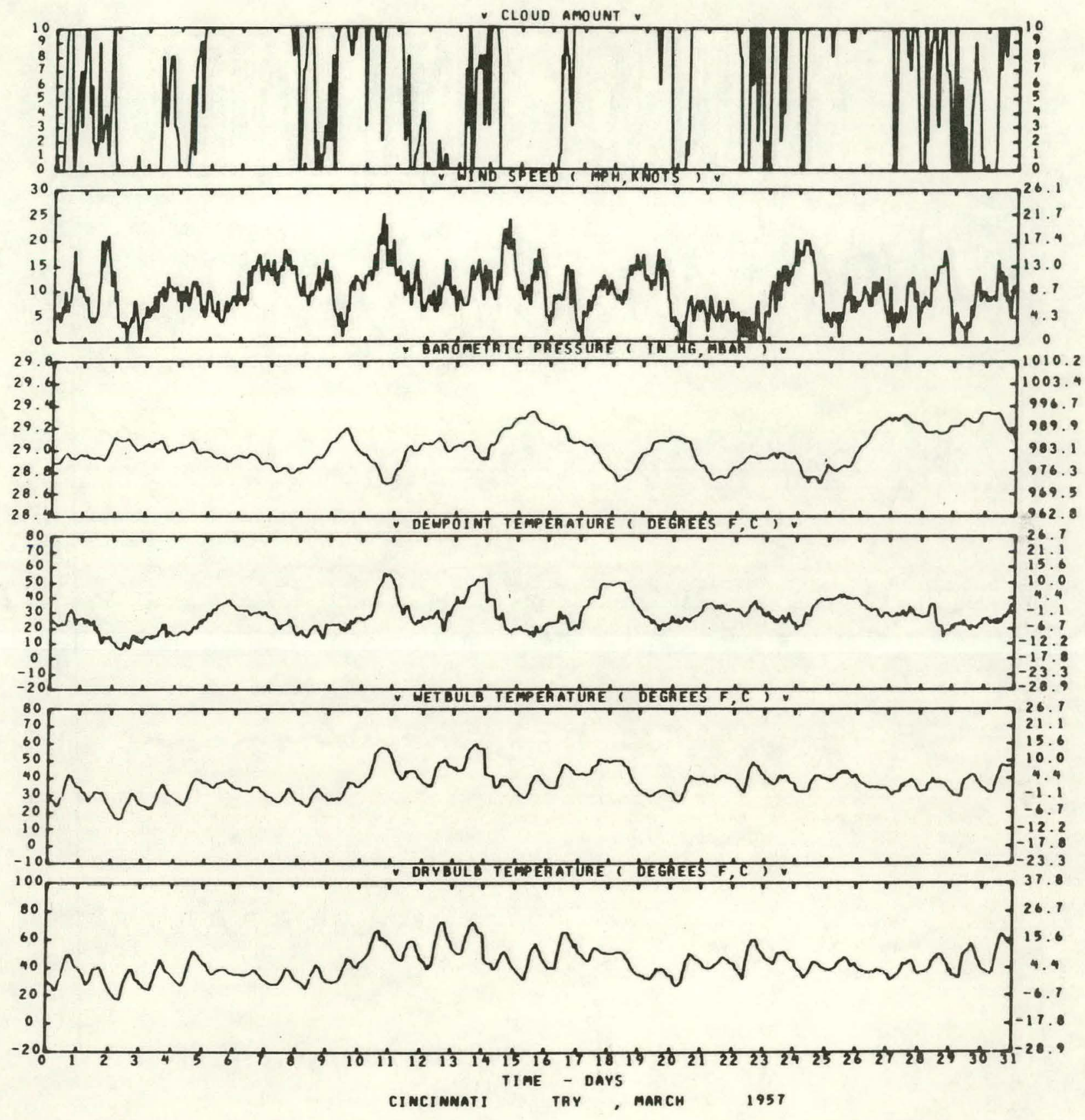

Fig. 29 (Contd.) 


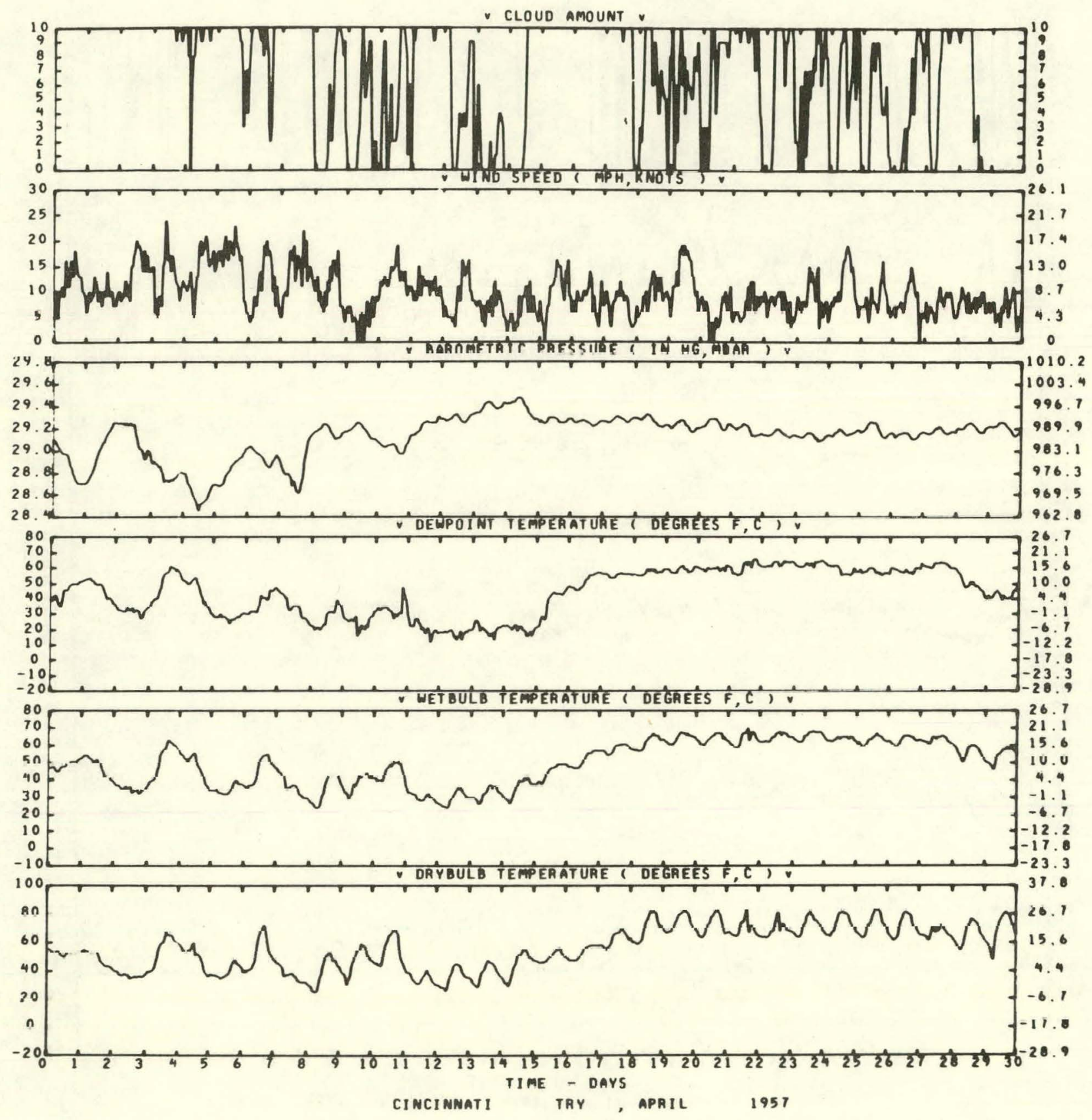

Fig. 29 (Contd.) 


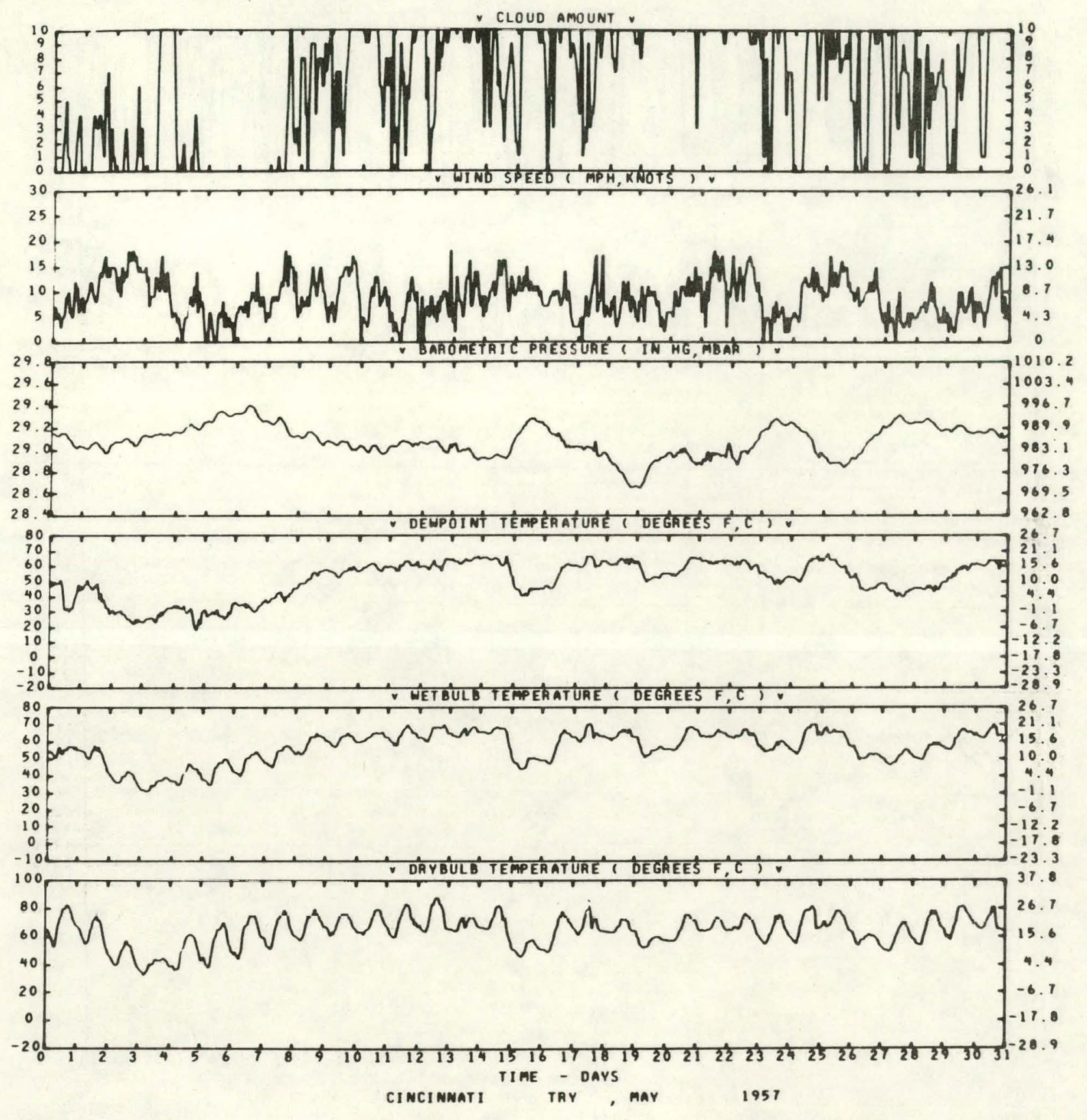

Fig. 29 (Contd.) 


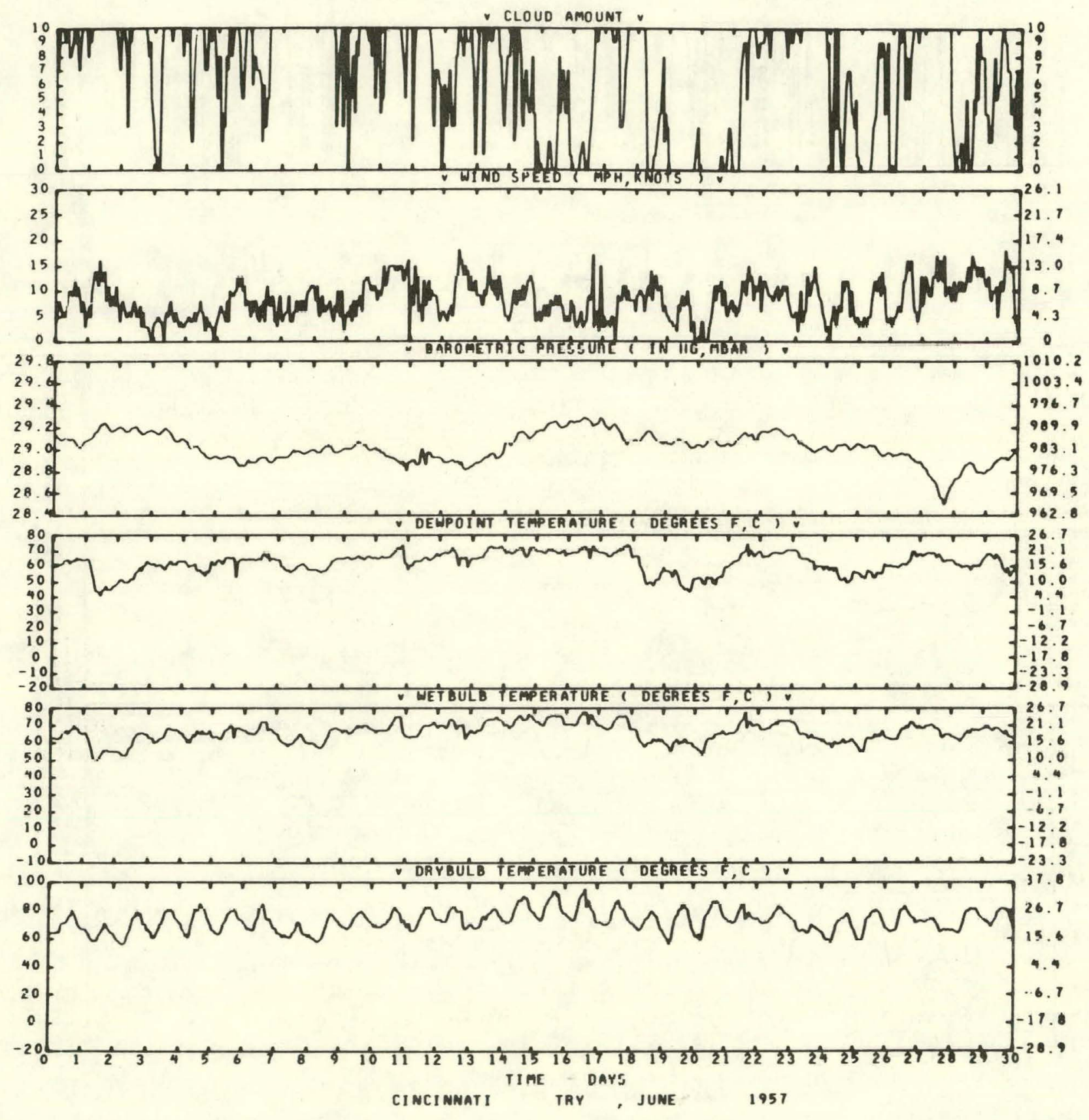

Fig. 29 (Contd.) 
99

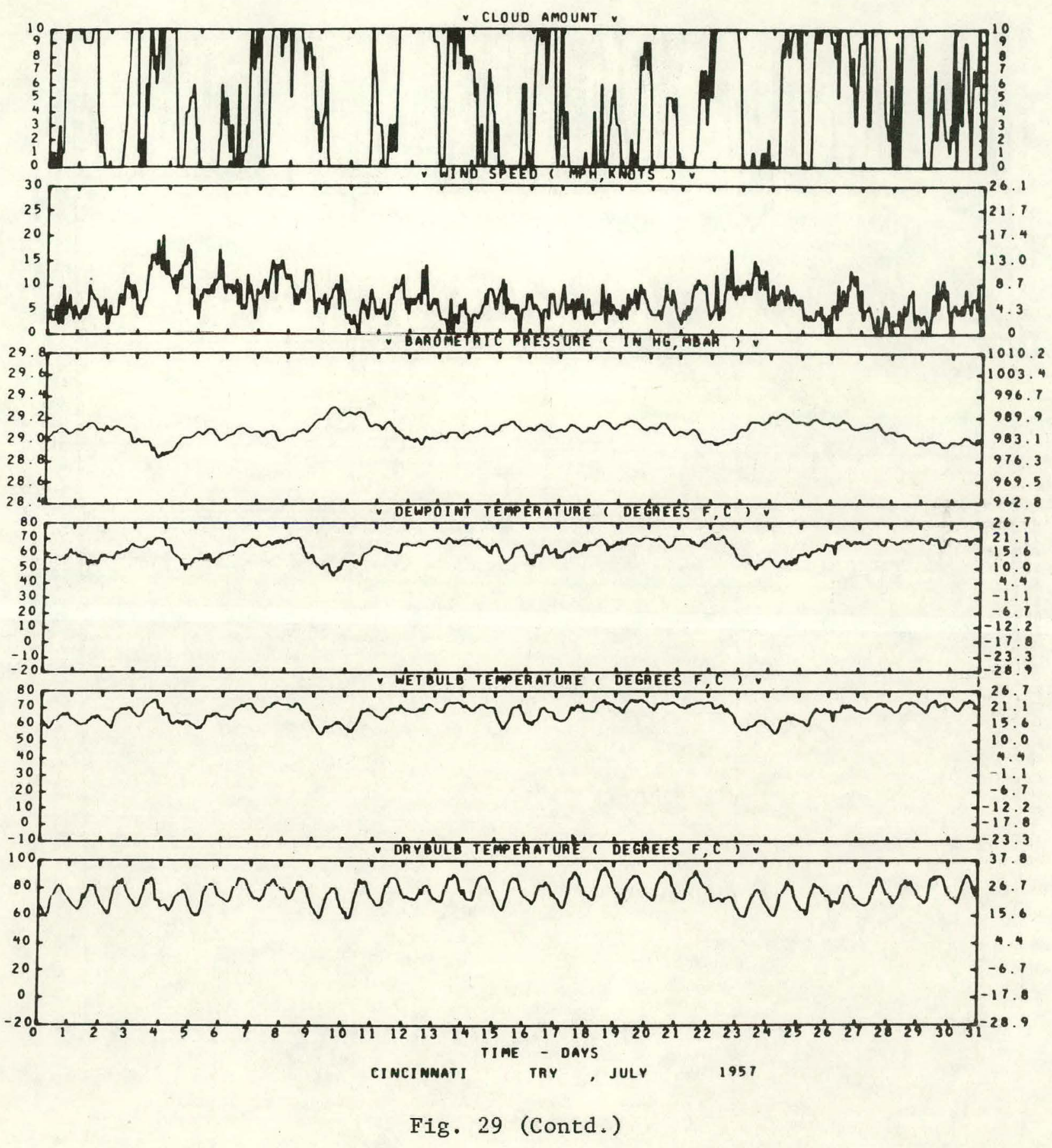




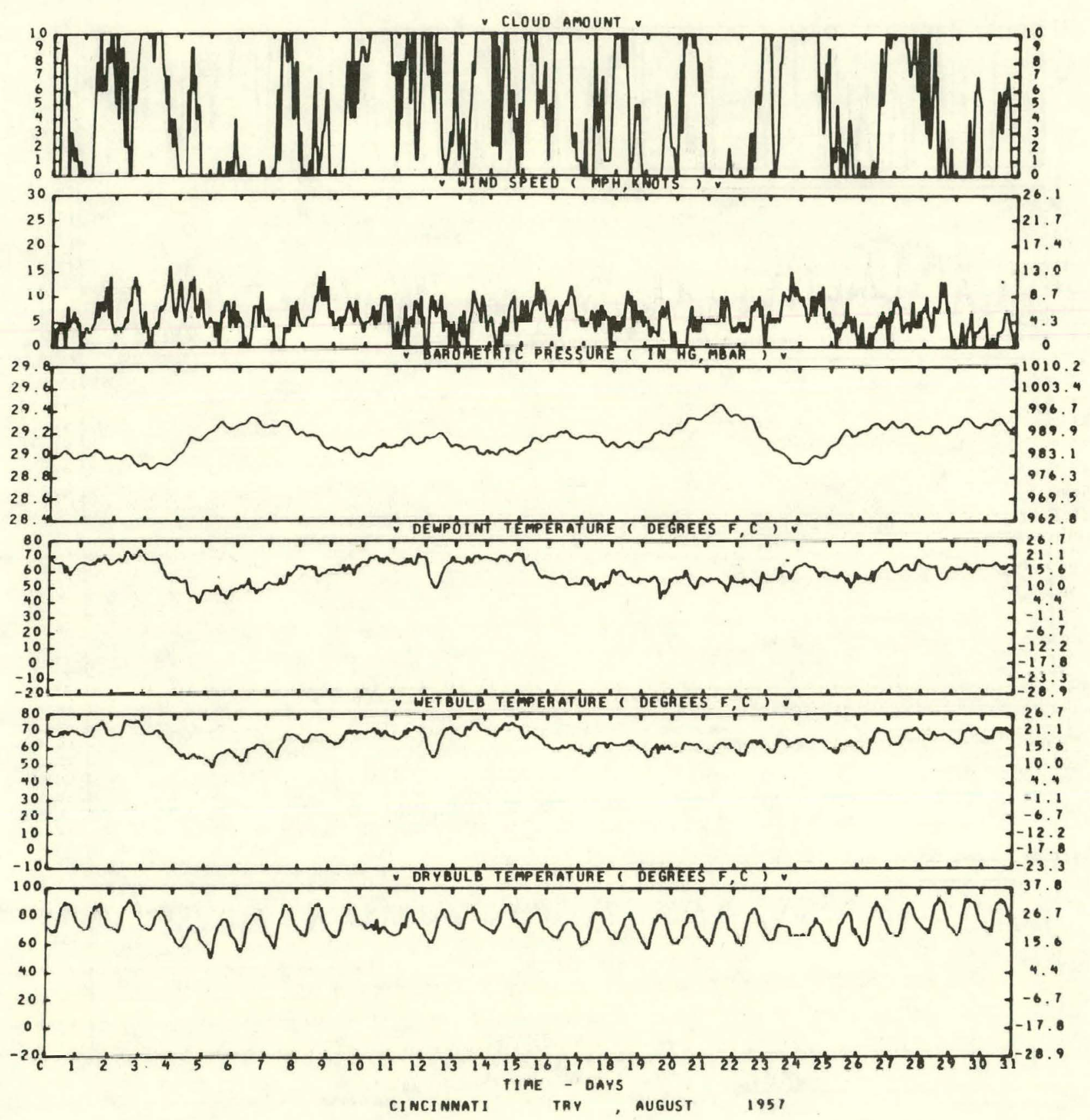

Fig. 29 (Contd.) 


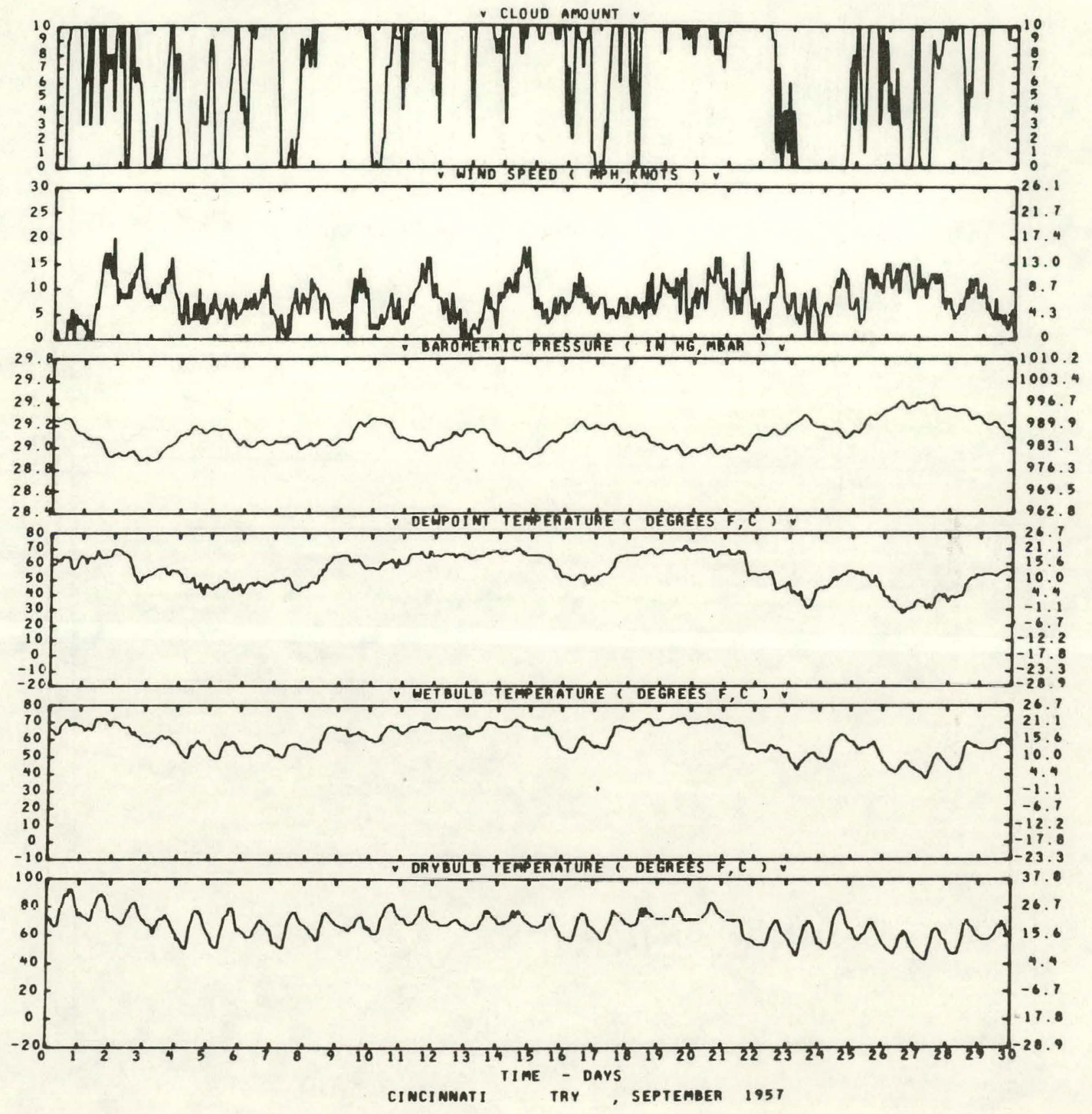

Fig. 29 (Contd.) 


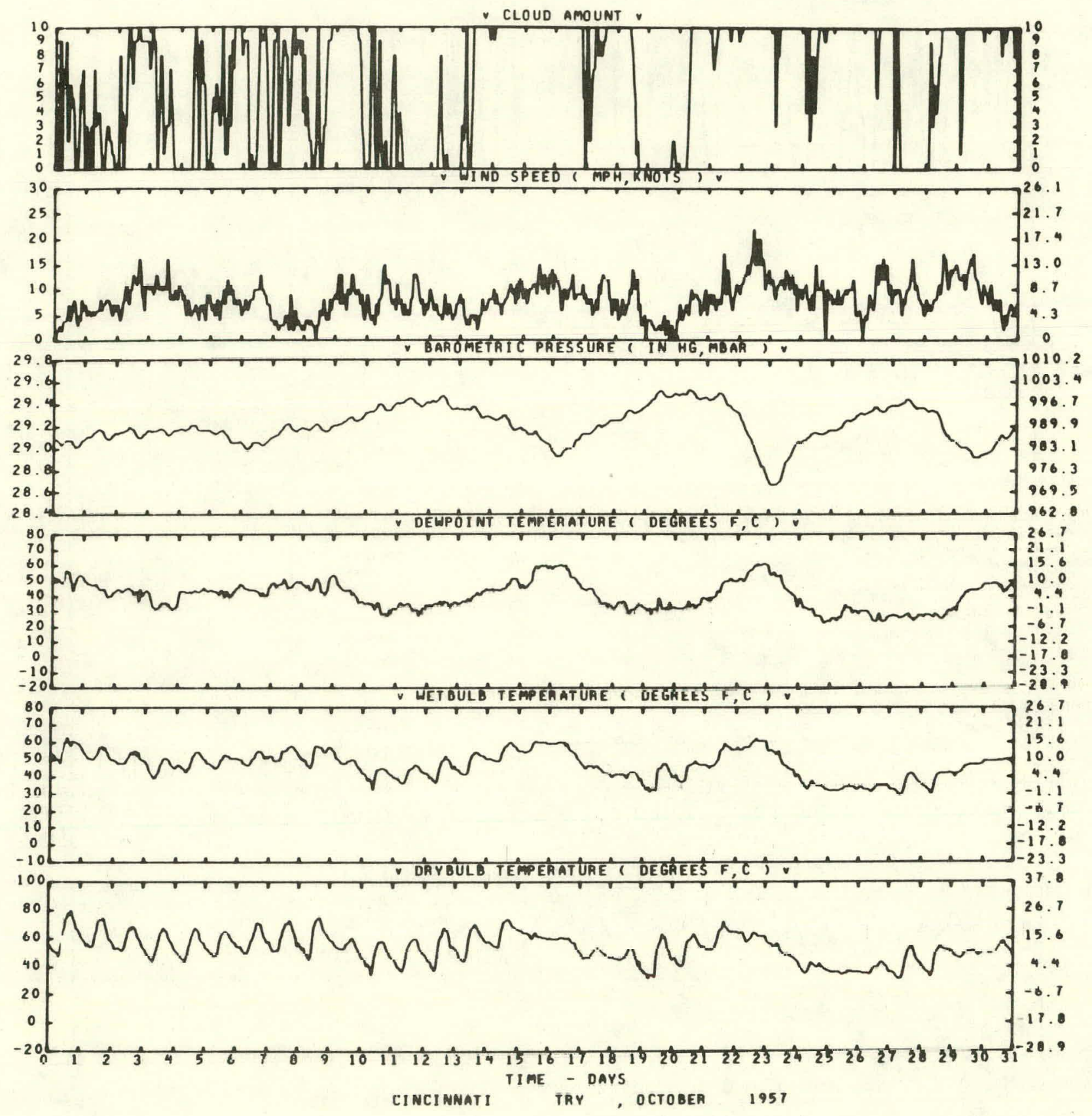

Fig. 29 (Contd.) 


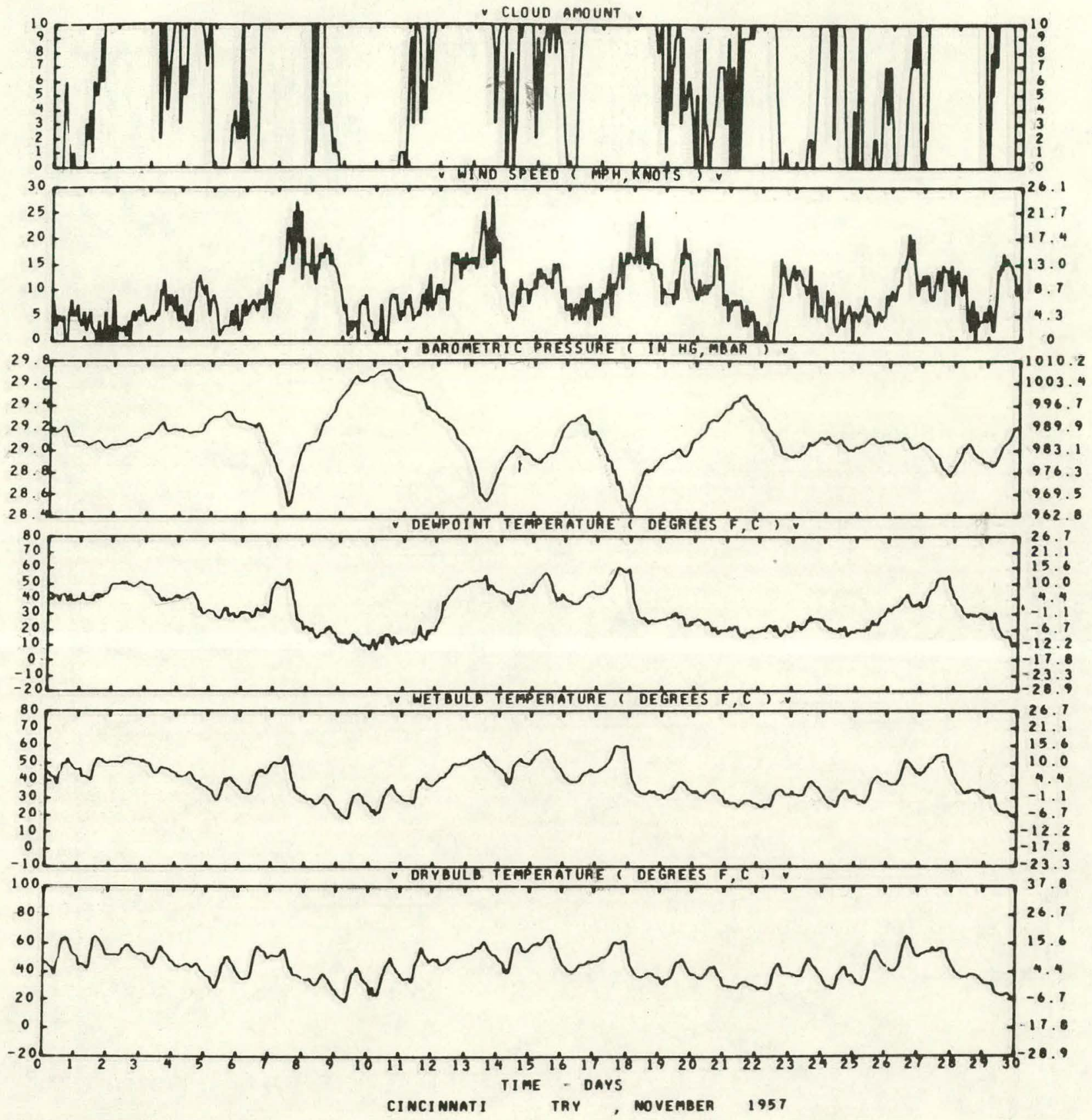

Fig. 29 (Contd.) 


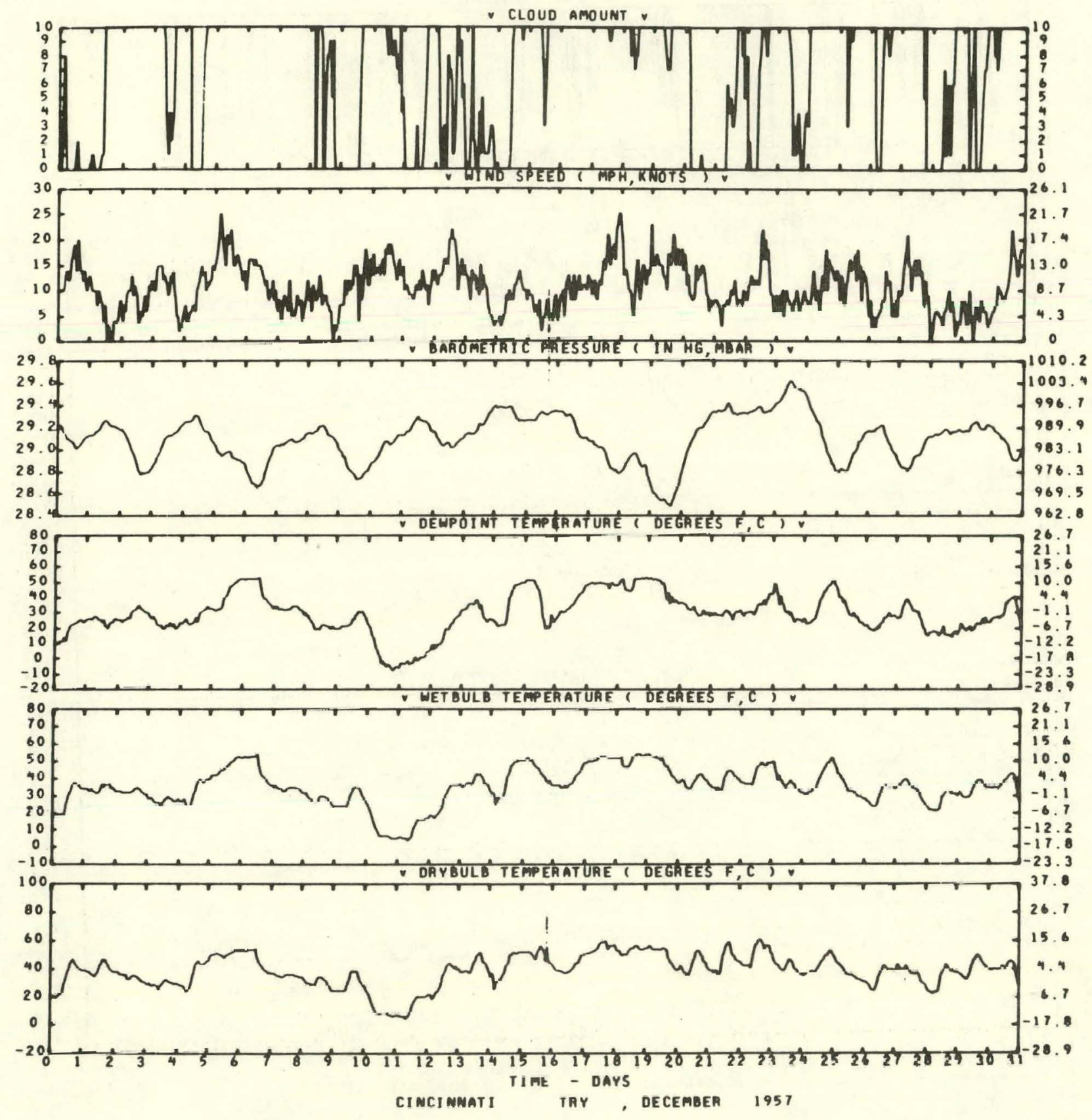

Fig. 29 (Contd.) 


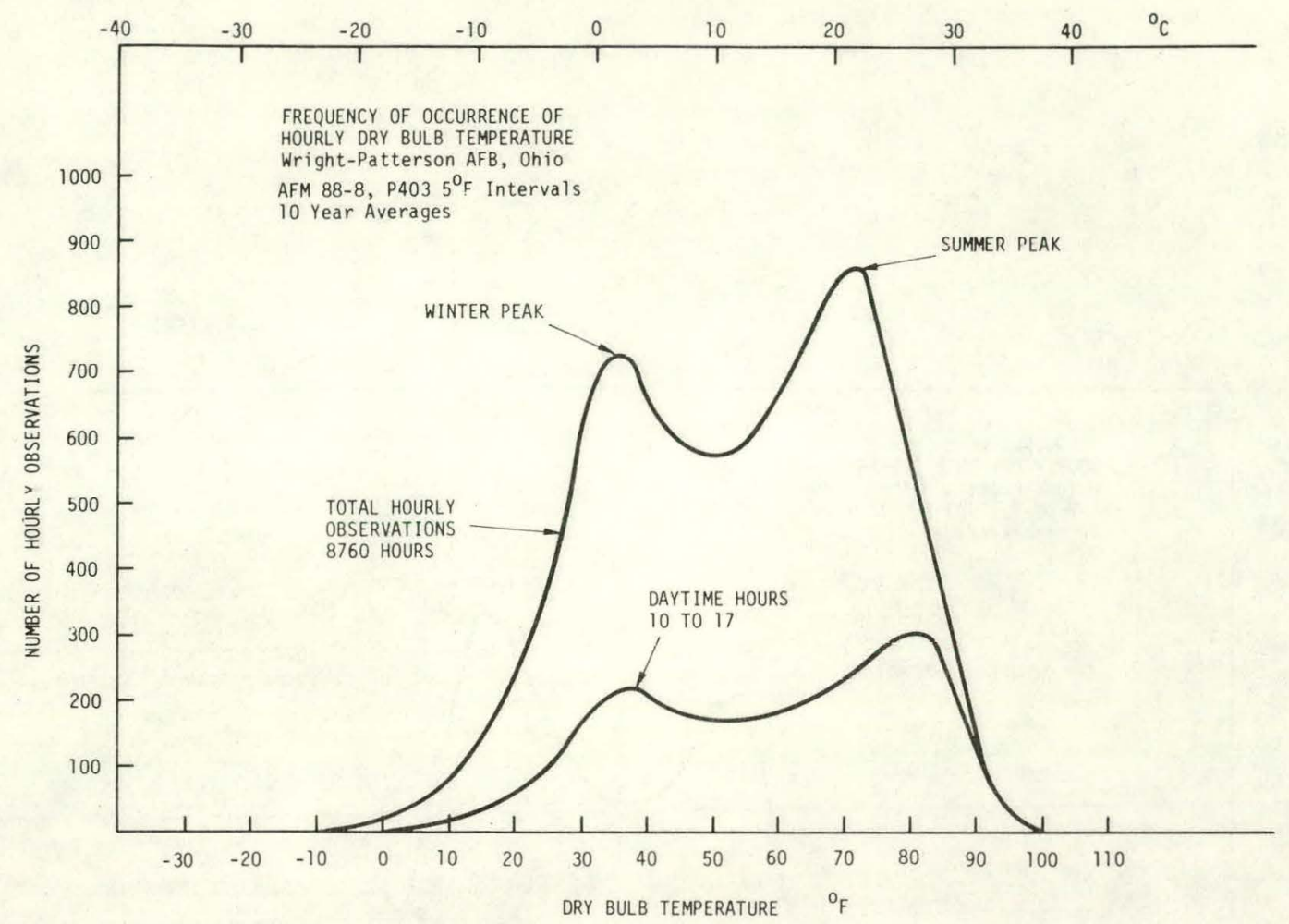

Fig. 30. Frequency of occurrence of hourly dry bulb temperature

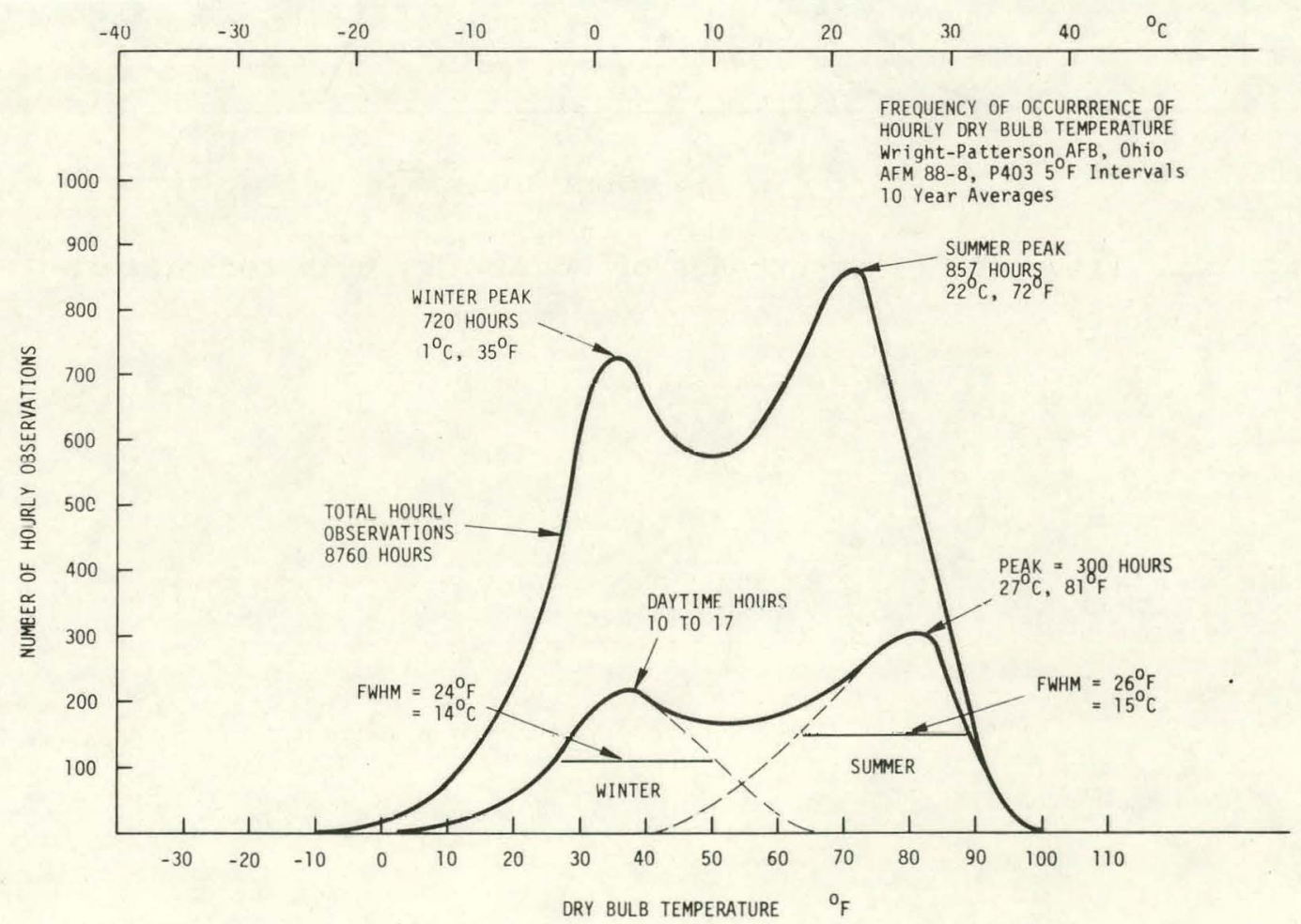

Fig. 31. Frequency of occurrence of hourly dry bulb temperature 


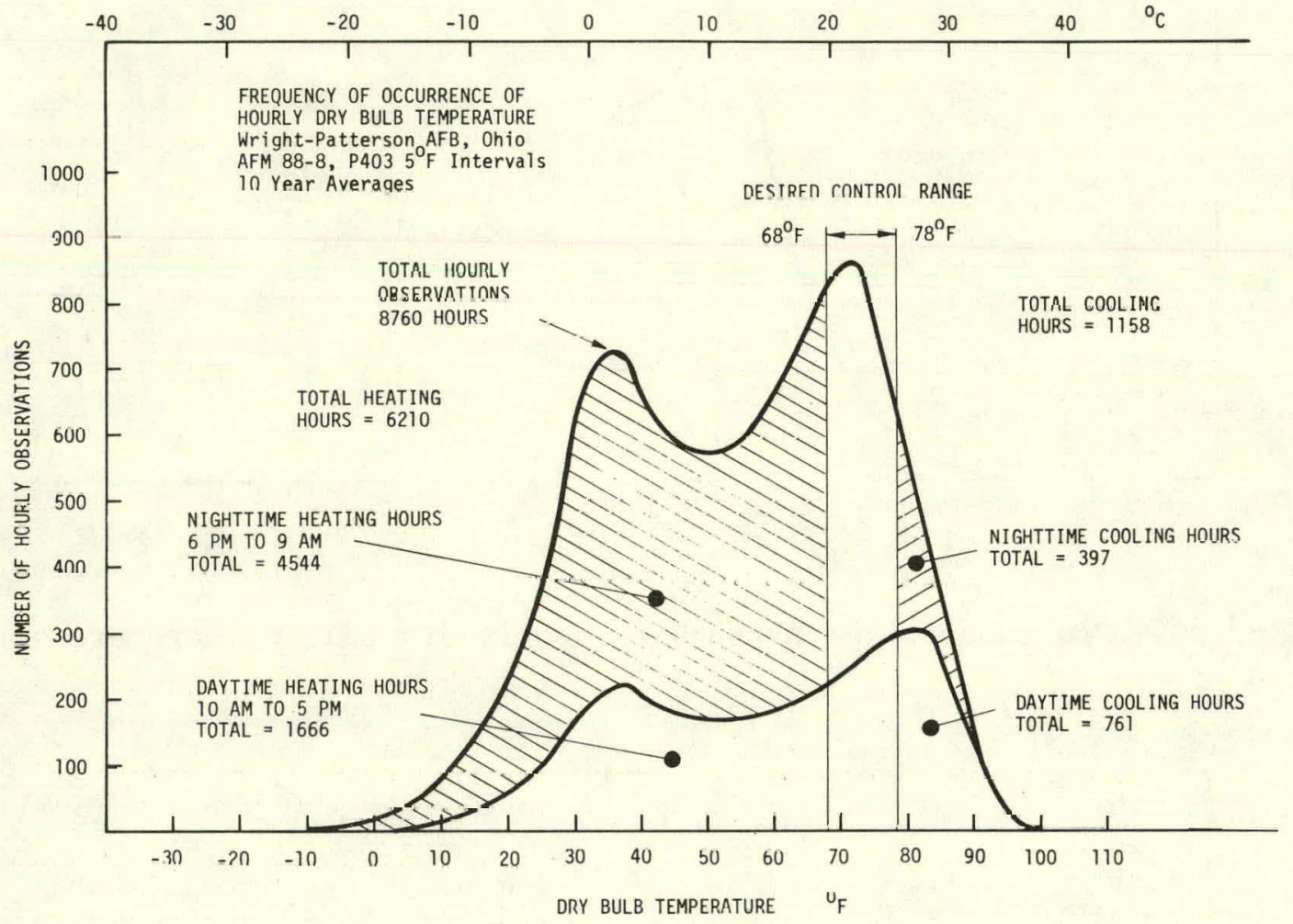

Fig. 32. Frequency of occurrence of hourly dry bulb temperature 


\section{CONCLUSIONS}

One of the main premises that must be accepted in utilizing computer programs to predict energy-consumption by buildings is the viability of the program itself. Many separate components are blended together to make up the DOE-1 computer program and inaccuracies can be easily spawned. While it is not within the scope of this project to test the accuracy of that program, it is helpful to know how close the calculated simulations are to the real values. Probably the simplest method of doing this is to compare the calculated energy demands for the test house with actual energy consumption obtained from the utility bills. Bear in mind that the model house is different from the actual house as made necessary by the DOE-1 procedure. These differences have been explained elsewhere in this report so it is not necessary to document them here. In addition, weather data used in the computer simulation may be far different from the climatic conditions under which the actual energy usage values were determined. This is pointed out under the section entitled "Weather Data". So caution is advised in interpreting these results.

Total actual energy use for the house which includes both electric and gas consumption averages 195.456 MBTU per year for the period from 1974 through 1978. Table 23 shows a computer printout of the systems load summary for the test house as modeled as a single zone with the SZRH dietribution system. The heating, cooling, and electrical demands as calculated under this simulacion are $-115.107 \mathrm{MBTU}, 3.645 \mathrm{MBTU}$, and $25,021.843 \mathrm{Kwh}$ respectively. Converting the electrical load to million BTU at a rate of $3413 \mathrm{BTU} / \mathrm{Kwh}$ yields a value of $85.39 \mathrm{MBTU}$ for the electrical demand. The addition of these thiee sums yields an annual 
calculated total energy demand of 204.142 MBTU. This represents a $4.25 \%$ difference from the actual consumption as determined from the utility bills. Needless to say, this difference is well within an acceptable error margin and is easily explained by variance in weather and by the input changes made necessary under the current format of DOE-1. Under normal computational practices, variances of up to $20 \%$ are allowed for due to the uncertainty of weather conditions alone. The fact that the two values are so comparable lends encouragement to the furcher use of computer programs as a useful luvl in predicting building energy consumption characteristics. 
TABLE 26. Single zone fan system load summary

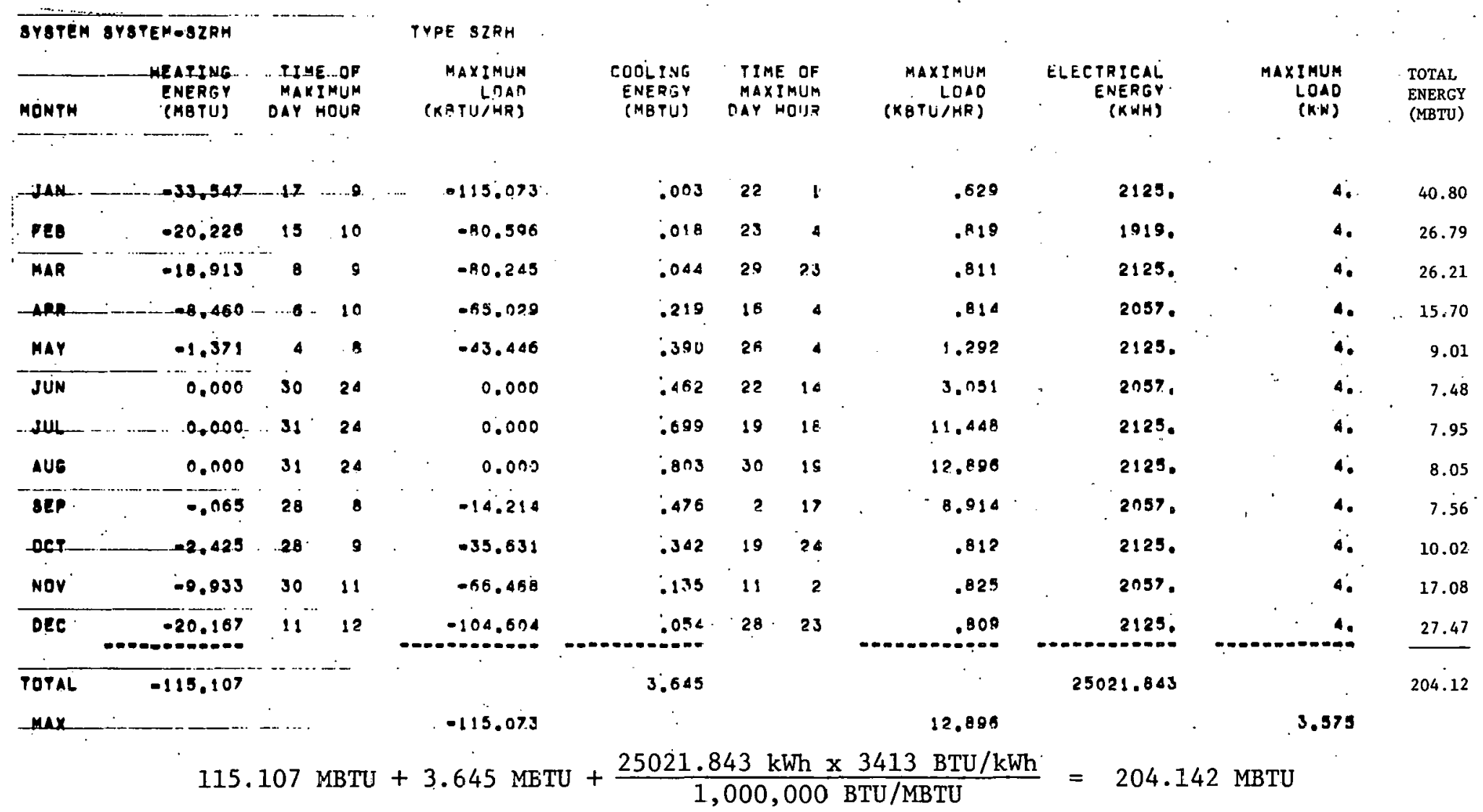




\section{ACKNOWLEDGEMENTS}

I would like to express my extreme thanks to Mr. Robert M. Graven . of Argonne National Laboratory without whose help and encouragement this project would have never been accomplished. His assistance is most appreciated. In addition, gratitude is also felt toward the entire Solar Energy Group at Argonne for their cooperation and support in the completion of my internship there.

I would also like to thank Dr. Justplı Cántiell, Dr, Joocph Priest, and Dr. Wallace Edwards of Miami University for their help in this project.

Finally, I express my sincere indebtedness to Miss Jackie Bertoletti of Argonne National Laboratory for invaluable assistance in the preparation of this manuscript. Her time and effort are worthy of the highest praise. 


\section{LITERATURE CITED}

AIP Conference Proceedings No. 25; Efficient Use of Energy. Series

Editor: Hugh C. Wolfe; American Physics Institute, New York, 1975.

Dumas, Lloyd J. The Conservation Response. Lexington Books, D. C. Heath \& Co., Lexington, Mass., 1976.

Dupree, Walter G. and. West, James A., United States Energy Through the

Year 2000: United States Department of Interior, Washington, D.C., 1972.

ERDA University Conference Proceedings: Energy Research and Development Administration, Washington, D. C. , 1975.

The Ford Foundation, A Preliminary Report of the Ford Foundation's Energy Policy Project, Washington, D.C., 1974.

Freeman, S. David, Energy: The New Era, Walker \& Co., New York, 1974. Hammond, Allen L., Metz, William D., and Maugh, Thomas H., Energy and the Future, AAAS, Washington, D.C., 1973.

Hottel, H. C. and Howard, J. B., New Energy Technology -- Some New Facts and Assessments, MIT Press, Cambridge, Mass., 1971.

Lenihan, John and Fletcher, William W., Energy Resources and the Environment, Academic Prcoo, New: York, 1970.

Stanford Reserach Institute (SRI), Patterns of Energy Consumption in the United States, Office of Science and Technology, Executive Office of the President; Washington, D.C., 1972.

Staff Study, The Potential for Energy Conservation. Executive Office of the President, Office of Emergency Preparedness, Washington, D.C., 1972.

Stoker, H. Stephan, Seager, Spencer L., and Capener, Robert L., Energy: From Source to Use, Scott, Foresman \& Co., Glenview, IL, 1975. 
Distribution for ANL-79-32

Internal:

J. G. Asbury

L. Burris

F. A. Cafasso

P. Chopra

R. L. Cole

E. J. Croke

J. E. Draley

P. R. Fields

B. R. T. Frost

P. F. Gustafson
W. Harrison

J. R. Honekamp

R. A. Lewis

E. I. Lin

A. I. Michaels

P. A. Nelson

E. G. Pewitt

D. C. L. Price

J. J. Roberts

N. F. Sather

W. W. Schertz (61)
J. F. Schumar

W. T. Sha

P. J. Styka

D. Webster

R. Winston

R. S. Zeno

A. B. Krisciunas

ANL Contract File

ANL Libraries (5)

TIS Files (6)

\section{Externa1:}

DOE-TIC, for distribution per UC-59c (343)

Manager, Chicago Uperations and Reglund Office, DOE

Chief, Office of Patent Counsel, DOE-CORO

President, Argonne Universities Association

Chemical Engineering Division Review Committee:

C. B. Alcock, U. Toronto

R. C. Axtmann, Princeton U.

R. E. Balzhiser, Electric. Power Research Inst.

J. T. Banchero, U. Notre Dame

T. Cole, Ford Motor Co.

P. W. Gilles, U. Kansas

R. I. Newman, Allied Chemical Corp.

G. M. Rosenblatt, Pennsylvania State U. 